\title{
BULLETIN
}

\author{
OF THE
}

UNITED STATES

\section{GEOLOGICAL SURVEY}

\section{No. 41}

WA S H IN G TON

GOVERNMENT PRINTING OFFICE 1887 

UNITED STATES GEOLOGICAL SURVEY

J. W. POWELL, DIRECTOR

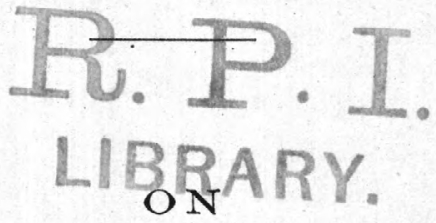

\section{THE FOSSIL FAUNAS \\ OF THE}

\section{UPPER DEVONIAN}

THE GENESEE SECTION, NEW YORK

BY

HENRY S. WILLIAMS

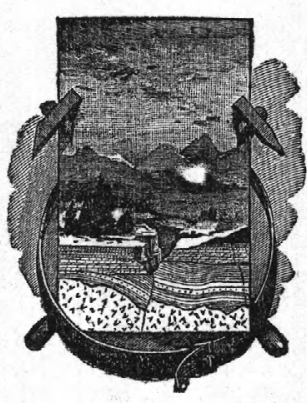

WASHINGTON

GOVERNMENT PRINTING OFFICE

1887 



\section{CONTENTS.}

Introduction

\section{Chapter I.}

Review of opinions; the bearings of these investigations upon the classification of the Upper Devonian rocks and faunas.............................

Prof. James Hall's views .......................................... 16

Prof. A. Winchell's views......................................... 17

Views on the relation of the Waverly to the New York series............ 17

Views of the Pennsylvania geologists ............................. $\quad 19$

The Allegany County section ................................... 20

Order of deposits in Ohio ........................................... $\quad 20$

Geographical and chronological relations of the faunas................ 21

List of the faunas........................................... 22

Relation of the faunas to the character of the deposits................ 23

Relation of the black shales to the upper faunas...................... 24

Place of the Venango oil group................................. 25

Strata following the Chemung faunas............................. 25

The interpretation of the facts................................. 27

\section{Chapter it}

Faunas of the Genesee shale and the Portage groups.................. 31

Description of two new lamellibranchs ............................ 35

Description of Lunulicardium levis ................................. 39

Description of two new Lucinas................................. 44

Description of worm tracks.................................... 46

\section{Chapter III.}

The Portage sandstones and the faunas of the Chemung group............ 51

Description of fish remains ...................................... 62

\section{Chapter IV.}

The Upper Chemung - the sands and the conglomerates................. 83

Description of Rhynchonella Allegania ............................ 87

Conclusions. .................................................... 103

Index.......................................................... 119 



\section{ILLUSTRATIONS.}

Page.

Plate I. Genesee section, approximate altitude of sections ................ 107

II. Map showing location of geologic stations of Genesee section....... 109

III. New species of fossils . . . . . . . . . . . . . . . . . . . . . . . . . . . . . . . . ... 113

FIG. 1. Dipterus Nelsoni Newberry ........................ 113

2. Dipterus ? lævis Newberry ........................ 113

3. Aptychus.................................... 113

4. Aptychus.................................... 113

5. Lunulicardium levis, $\mathrm{n} . \mathrm{sp} \ldots \ldots \ldots \ldots \ldots \ldots \ldots \ldots \ldots . . . \ldots \ldots$

6. Lunulicardium levis, n. sp ........................ 113

7. Lunulicardium fragile Hall ......................... 113

8. Lunulicardium levis, n. sp ........................ 113

9. Ptychopteria ? mesocostalis, n. sp .................. 113

10. Pterinopecten ? Atticus, n. sp....................... 113

11. Pterinopecten? Atticus, n. sp...................... 113

12. Ptychopteria ? mesocostalis, var.................... 113

13. Lucina Wyomingensis, n. sp ...................... 113

14. Lueina Varysburgia, n. sp ........................ 113

IV. New species of fossils. ................................... 117

Frg. 1. Rhynchonella Allegania, n. sp...................... 117

2. Rhynchonella Allegania, n. sp.................... 117

3. Rhynchonella Allegania, n. sp.................... 117

4. Rhynchonella Allegania, n. sp ...................... 117

5. Rhynchonella Allegania, n. sp ..................... 117

6. Rhynchonella Allegania, n. sp ...................... 117

7. Rhynchonella Allegania, n. sp...................... 117

8. Rhynchonella Allegania, n. sp ...................... 117

9. Arenicolites duplex, n. sp ....................... 117 



\section{LETTER, OF TRANSMITTAL.}

DePaRTMENT OF THE INTERIOR, United States Geological Survey, IтінасA, N. Y., A A ugust 2, 1886.

SIR: I have the honor to transmit herewith for publication as a bulletin a second contribution to the study of Devonian paleontology, Bulletin No. 3, "On the Fossil Faunas of the Upper Devonian," having been designed as the first of a series of papers on the comparative paleontology of the Devonian and Carboniferous.

In that paper I gave the results of a study of the section along the meridian of Ithaca and Cayuga Lake, running southward, which may be called the, Cayuga section.

In 1883 examination was made south along the meridian running through Genesee County, New York, into McKean County, Pennsylvania, where the Alton coal beds were reached. The general results of this survey were communicated to the Director of the United States Geological Survey and an abstract of my communication was published in Science, Vol. II, pp. 836, 837, December 28, 1883. The present paper is a detailed report of the study of the materials of this Genesee section.

Since the field work was done several additional sections have been examined: in 1884, sections through Western New York (and adjoining Pennsylvania) from Chautauqua County westward and into Ohio as far as the meridian of Cleveland; and in 1885 the region between the Cayuga section and those of Delaware and Otsego Counties, as far as Oneonta, were examined. The materials are under investigation and will be reported upon as soon as their study is completed.

The sections are made along meridians, in order to make them more readily and simply comparable. Each long meridional section runs through the same stratigraphical series of deposits and is made up of a series of small local sections, such as the individual outcrop of the rocks renders possible.

It is not supposed that in any case these sections are exhaustive, but it is intended that so far as they go the relative position of the faunas in the sections shall be precise and the association of species in each horizon shall be given as it is, so that the faunas can be identified, and thus, while they will leave much to be added, these studies, it is hoped, will give an outline of the geographical distribution and geological range of 
faunas and their species which will make a comparative study of the faunas possible.

In the arrangement of the material of this report I have followed simply the order in which the various sections were originally made, which is in general from north to south and from below upward. The num. bering of the stations is that which the specimens will receive when finally deposited in the National Museum. The system used in marking the sections and the specimens representing them is as follows: A number is assigned to each principal locality, as 468 Attica, $477 \mathrm{Cuba}, 487$ Olean, \&c. A letter is assigned to each section, as 477 A, Armstrong quarry, Cuba; $477 \mathrm{C}$, Smith quarry ; $477 \mathrm{E}$, a ravine south of Cuba. For each section the individual strata or fossiliferous zones receive numbers, running from below upward wherever this order was practicable; thus $477 \mathrm{E}^{2}$ is the principal brachiopod zone of this particular ravine, $477 \mathrm{E}^{5}$ the red band of the same section.

In the present report special discussion of the faunas of the Hamilton group and of those below the black shales of the Genesee group is omitted, since the sections along this meridian do not present the series with sufficient fullness to throw any new light upon their history. The facts gathered will be presented in their connection when a more typical series of this part of the Devonian is prepared for comparison.

Respectfully yours,

HENRY S. WILLIAMS.

Maj. J. W. Powell,

Director U. S. Geological Survey. 


\title{
UPPER DETONIAN FOSSIL FAUNAS-GENESEE SECTION.
}

\author{
By Henky S. WiLliams.
}

\section{INTRODUCTION.}

The description of fossils is a most important work for the paleontologist, but it is believed that a still more interesting and a wider field is awaiting his investigation in the comparative and historical study of organisms. This field is open for all who will undertake it, and, while the professional paleontologist may be able to map out the grander features and problems, very much must be left for the local st udent to fill in by careful and thorough search in his own region. This same line of investigation should be followed out in all the geological stages, and each student will find his best field in that region in which he can make most diligent search. In the present case the selection of the Devonian was determined by the simple fact that the Devonian rocks were for the writer the most accessible. These outcrops are near at hand and therefore can be thoroughly studied. The Silurian offers like opportunities for those residing in the midst of Silurian rocks, the Mesozoic for others.

Scarcely ever do good species range through more than a single geological system, and hence a scrutiny of the laws of the modification of species may be best effected by confining our comparisons to the species of a single system. Till we gather some definite knowledge as to the laws of modification which species undergo when traced thro ugh varying: geographical conditions and in their geological range, our ideas in regard to modification of genera and families must necessarily be hypothetical. It is hoped, too, that these investigations may throw some light upon the nature of what we call species - as to wh at may be the conditions determining the constancy of certain characters an d theplasticity of others. In order to do this, data must be collected showing what the constant and what the plastic characters act ually are, and this in regard to particular species, at particular stages, and in particular regions.

In a paper read at the Ann Arbor meeting of the American Association for the Advancement of Science, 1885, I communicat ed some of the general results of comparison of the several faunas of the Upper Devonian, 
as seen in the various sections from Oneonta, Otsego County, N. Y., westward to Cleveland, Ohio. I then named the several long sections whose faunas were made the subjects of comparison. The section described in the present paper is there called the Genesee section. In reference to the identification of species in this paper, I wish particularly to state that I regard them in many cases as imperfect and provisional.

The careful comparison of large series of specimens from the same and from different localities and from different zones has brought out so conspicuously the variability in many of the characters used in the definition of species that the limitation and the validity of species are often called in question. But in order to speak of them and to discuss the problems involved it is necessary to use some names. The rule $I$ have adopted, therefore, is to apply to specimens which have come from the same localities and horizons the names which are in common use in the reports and in the museums where the typical specimens $m$ ay be found named and described. The literature, too, is often confused, and forms which ought to go under a single name are often called by different names by different authors. This is particularly noticeable when comparisons of our material are made with collections from Europe or from distant portions of our own land. Further, there are in common use in our American literature generic names of very doubtful value, which may be dispensed with to the advantage of science. But to adjust these errors would involve technical and detailed discussion, not appropriate to this paper, and $I$ have therefore somewhat sacrificed precision in the use of nomenclature in order to bring out more clearly, for those familiar with the State reports and the museums in which the typical collections are contained, the general characters of the faunas.

As preparation for these investigations I owe much to the abundant and instructive labors of geologists and paleontologists who before me have studied deeply into the problems and done much toward their solution. In this country, Messrs. James Hall, J. S. Newberry, A. Winchell, O. A. White, and later Messrs. John F. Carll, I. C. White, C. A. Ashburner, and H. M. Chance, in connection with Prof. J. P. Lesley, of the Pennsylvania survey, and Mr. Edward Orton, the present State geologist of Ohio, Messrs. F. B. Meek and A. H. Worthen, of the Illinois survey, and Mr. Carl Röminger, of the Michigan survey, and others, in a more general way, have taken more or less active part in elaborating the facts and in determining the relations which the complicated series of deposits sustain toward one another. In Great Britain the discussion which centered about the Devonian problem, the relation of the Devonian marine deposits and the Old Red Sandstone, is full of instruction, beginning with the classic paper of Murchison and Sedg. wick, and expressed most forcibly in the papers of Murchison, Salter, Jukes, Hall, and Champernowne, and practically settled for Great Britain in the exhaustive paleontological paper of Sir Robert Etheridge 
in 1867. Most of these articles may be consulted in the Transactions and Journal of the Geological Society of London. Recent investigations on the Devonian series of Northern France and Belgium have thrown light on the general problem. The papers of MM. Gosselet, Barrois, and Mourlon may be specially mentioned. Valuable suggestions are also found in the papers of M. Emanuel Kayser on the Rhen. ish Devonian.

All these investigations tend to show, first: that the series of deposits which immediately preceded the Carboniferous formation, or those deposits which are of a semiterrestrial origin, at the close of the Paleozoic exhibit great variation in the nature and order of the deposits when traced over any considerable geographical area. The termination of the Devonian age and deposits underlying the true Carboniferous age have been a constant source of bewilderment to all geologists in this country who have looked outside their own immediate neighborhood. Secondly, when studied minutely, there appear to be evidences to show that the differences in the faunas in these deposits are not always chronological differences, but must be regarded often as geographical in faunas living at the same time under different conditions.

From the fact of these differences and irregularities in the deposits and in their contained faunas, they seemed to offer a particularly attractive field for studying the effects of changing conditions upon the organisms and a promising field from which to learn the la ws of change which, under like conditions, might be traceable to chronological sequence, and at a common horizon could be more properly referred to geographical change of the environing conditions of life. 



\section{CHAPTER I.}

\section{REVIEW OF OPINIONS; THE BEARINGS OF THESE INVESTIGA- TIONS UPON THE CLASSIFICATION OF THE UPPER DEVONIAN ROCKS AND FA UNAS.}

In planning these investigations into the history of organisins, the Devonian age was chosen as a particularly important field because of the numerous disputed questions there awaiting solu tion and becanse it offers, in the various exposures in this country, abund ant data for investigation. Between the limits of the Corniferous li mest one below and the coal deposits above is found a great thickness of strat a in New York, Pennsylvania, and adjacent territory broken up in to several well marked geological formations. In other parts of the United States the same series is represented by deposits containing like fossils but not always identical, nor are successive strata always composed of the same materials or arranged in the same groups as we pass out of this eastern area.

When these investigations were begun the chief question in mind was the solution of the complex problem of the equiva lency of the various sections covering Upper Devonian and Lower Carboniferous horizons in various parts of the country. The first general section therefore did not extend below the Black Genesee shale terminating the Hamilton formation. The faunas from this point to the first coal, as seen along the meridian from Cayuga Lake southward, were reported upon in the United States Geological Survey Bulletin No. 3. But the pro blems involved are too far reaching to be limited by so indefinite a mass as the black shales lying in the Middle Devonian of New York. Although this section through the middle tier of coun ties in Western New York is an admirable one for the study of the Upper Devonian, it will be necessary to go farther east to find the lower faunas (i. e., above the Corniferous limestone) so exhibited as to determine the details of their history.

On entering upon fields of which the geological structure is well known and whose fossil species are generally familiar an d described, I neither undervalue the excellent work of my predecesso rs nor expect to do anything to take the place of the geological reports already published. On the other hand, the work here attempted could not be under. taken without this preliminary mapping oit of the field and working up of the species concerned.

I am here interested not in adding to the long list of described species, nor in determining to what geological period the species be. 
long, but in ascertaining the laws of association, of sequence, of modification, and of distribution of species in the past. The better known and the more frequent the occurrence of the species the more satisfactory will be the results to be reached by their study. In the course of the investigations already a few new species have appeared, but much more frequently forms have been met with which lie intermediate between the typical forms of already described species.

Facts are thus accumulated for a revision of the characters essential to the distinction of species. Not only am I indebted to the work of other geologists for facts accumulated, but suggestions and partial explanations of the facts, so far as the evidence existed, have been used as guides in extending the research. I have availed myself, too, of the differences of opinion among accepted authorities as a guide to the questions needing most careful study.

On examining the series of deposits found in each State, it was of first importance to consult the published reports of geological surveys already made. I have, therefore, consulted the numerous series of reports of the State surveys of New York, Ohio, Pennsylvania, Michigan, Iowa, Missouri, Illinois, and of other States in which representative deposits were exposed.

\section{PROF. JAMES HALL'S VIEWS.}

In the volume on the Deronian Brachiopoda, 1867 (Geol. Surv. of N. Y., Pal., Vol. IV, Pt. I), Prof. James Hall recognized the increase of Uarboniferous types among the species of the Upper Devonian on passing from the eastern to the western deposits of New York State; this he regarded as a mark not of a higher geological stage, but of a change in geographical conditions. He wrote (p. 257): "And finally, we have every reason to believe that in those sedimentary formations between the Hamilton group and the Coal Measures in the east, and between the same groups and the Burlington (Carboniferous) limestone in the west, the Devonian aspect of the fauna on the one hand and its Carboniferous aspect on the other are due to geographical and physical conditions, and not to difference in age or chronological sequence of the beds containing the fossils."

The mingling of Devonian and Carboniferous types in rocks of the Lake Superior region occurred to Professor Hall still earlier (see Rep. Geol. Lake Superior Land District, Foster \& Whitney, 1851, p. 313), leading to the belief that the transitions are gradual and not clearly defined.

This idea, whether originating with Professor Hall or not, was never elaborated by him in public, so far as I can ascertain. In Great Britain, however, the discussion of the relations existing between the Devonian and the Old Red Sandstone, which practically terminated in Sir Robert Etheridge's masterly paper on "The physical structure of West Som- 
erset and North Devon" in 1867 (Quar. Jour. Geol. Soc., London, Vol. XXIII), has brought out clearly the fact that the Old Red Sandstones, wanting in marine invertebrate faunas and filling the gap between the marine deposits of the Silurian and those of the Carboniferons, are the equivalents of the marine deposits called Devonian - not above nor below them, but contemporaneous, though in separate geographical areas.

The change in the character of the American deposits in passing westward and the differences observed in the faunas were explained by Professor Hall as due to mingling of the Devonian and Carboniferous faunas toward the west.

\section{PROF. A. WINCHELL'S VIEWS.}

In 1870 Prof. A. Winchell, in a paper (in Proc. Am. Phil. Soc., Vol. XI, pp. 57-82, 385-418) "On the geological age and equivalents of the Marshall group," objected to this interpretation of the facts, which implied, if it did not assert, that the Waverly and Marshall groups were only geographical modifications of formations of the same general age as the Chemung. Professor Winchell brought elaborate evidence to show that the Marshall, Waverly, and allied faunas in Illinois, Indiana, Iowa, and Missouri were equivalents, that they were not equivalent to the Chemung group of New York, and, finally, that they were separated from the latter by the Catsikill group of Eastern New York, which was regarded as following the Chemung and intermediate between the Devonian and the Carboniferous age.

The problem of chief interest to the general geologist awaiting solution in these regions is that of the equivalency, or even the interpretation of the true relations, of these several series of rocks between the Hamilton and the Coal Measures, especially in the contiguous States of New York, Pennsylvania, and Ohio.

In the earlier surveys the Upper Devonian was traced far into the interior, and the Waverly of Ohio, the Burlington sandstone, and the Chouteau beds of Missouri were alike regarded as equivalent to the New York Chemung.

In 1867 Professor Hall receded from this position and recognized the force of Professor Newberry's discovery of Spirifera Verneuili (= S. disjuncta) below the Cleveland shale (see Geol. Surv. N. Y., Pal., Vol. IV, Pt. I, note at beginning). In 1870 the superior and independent position of the Waverly and equivalents was defended by Professor Winchell in the paper above mentioned.

VIEWS ON THE RELATION OF THE WAVERLY TO THE NEW YORK SERIES.

In 1875, Professor Hall, finding the fossils of the Chemung group in the higher beds of Western Pennsylvania mingling with other species regarded as Carboniferous, concluded that "the Chemung fauna contin-

Bull. $41-2$ 
ued its existence till after the appearance of Carboniferous forms, and that the two faunas, if they can be properly so regarded, lived in the same sea and at the same epoch; and the question of the limits between Devonian and Carboniferous formations is likely, at least for some time, to remain undetermined in some parts of the country." (Am. Jour. Sc., 3d ser., Vol. XII, pp. 303, 304.)

In 1878 Professor Newberry defended his early opinion regarding the Ohio equivalent of the Chemung as terminating at the base of the Cleveland shale (see Geol. Surv. Ohio, Vol. III, Geol., p. 14); but this opinion is complicated by the further one that the upper part of the Portage group is the proper base of the Carboniferous series, making these disputed beds merely a base of the Carboniferous.

The confusion in regard to the fossils of these Upper Devonian beds leaves the matter of exact equivalency still in doubt. That is, the mingling of faunas which led Prof. James Hall to regard the Chemung fauna as continuing into the Carboniferous and Prof. J. S. Newberry to draw down the limits of the Carboniferous so as to include the Chemung and the Upper Portage has not yet been satisfactorily interpreted. We see then that this confusion and occasional blending of faunas were variously interpreted by those who gave the subject most careful study. The New York State geologist (Hall), without distinguishing the faunas, regarded them as blending, and he left the relations of the New York and western beds undecided. The Ohio geologist (Newberry), from his standpoint of a Carboniferous Waverly group, brought down the Devono-Carhouiferous point of transition to the Portage sandstones of New York, thus including the Chemung group within the Carboniferous; while the Michigan geologist (A. Winchell), recognizing the integrity of his Marshall group formation, but finding still no equivalent fauna for it in the New York series, regarded it as the equivalent of the brackish or fresh water Catskill group, thus putting it above the Chemung group of New York as then defined. ${ }^{1}$

VIEWS OF PENNSYLVANIA GEOLOGISTS.

Since 1875 the Pennsylvania geologists, under Prof. J. P. Lesley, finding the fossils entirely unsatisfactory as means of determining the

\footnotetext{
${ }^{1}$ Since the writing of this paper, at the Philadelphia meeting of the American Association for the Advancement of Science, in 1884, Prof. James Hall communicated a paper entitled, "Note on the intimate relations of the Chemung group and Waverly sandstone in Northwestern Pennsylvania and Southwestern New York." (Proc. Am. Assoc. Adv. Sc., 1884, Part II, p. 416.) The paper is based upon a section in Warren County, Pennsylvania, made by Mr. C. E. Beecher and Mr. F. A. Randall. In this section the Chemung is regarded as running up to the base of the Waverly, and at the junction is said to be "the place of the Catskill," where "there is a hiatus which, in Eastern New York and Pennsylvania, is marked by the presence of measures having a thickness of from 3,000 to 5,000 feet" (p. 418), and Professor Hall concludes that "the deposition of the estuary Catskill sediments has been going on simultaneously with the open sea deposits of the Waverly formation."
} 
transition beds, adopted stratigraphical conditions as their chief criteria, and Mr. John F. Carll, Prof. I. C. White, Mr. C. A. Ashburner, and Mr. H. M. Chance have given in their several valuable reports various interpretations of the series.

The one point in which they all appear to agree is the equivalency of whe Olean-Garland-Ohio Conglomerate, altLough in $1876 \mathrm{Mr}$. E. B. Andrews, formerly of the Ohio survey, objected with strong argument to regarding the Conglomerate underlying the Coal as marking a common horizon for even the Ohio-Pennsylvania-Virginia area, and suggested that it would be more appropriate to call this a rock than a common horizon. (See Proc. Am. Assoc. Adv. Sc., Vol. XXIV, Pt. II, p. 84.) The Pennsylvania geologists, taking this Olean Conglomerate as a definite common horizon, recognize a sub-Olean Conglomerate, which in their northwestern counties takes its place below the Olean Conglomerate and above the horizon to wbich the red beds of the east and their equivalents are assigned. This lower Conglomerate, often merely a sandstone, is distinguished by its flat pebbles, although frequent sandstones and conglomerates are recognized below, having flat and worn pebbles.

When we go below this horizon confusion is greater the greater the number of counties whose sections are compared, but in the northwestern counties, where the red beds offer least trouble by their presence, frequent heavy sandstone beds separated by shales and thinner shaly sandstones are found occupying at least several hundred feet. These have gained the more general name of the Venango oil sands.

Mr. J. F. Carll (Report III, Second Geol. Surv. Pa.) gives several systems of sandstones and shales below this before reaching what he regards the equivalents of the New York Chemung. Prof. I. C. White (QQQQ, 2d Geol. Surv. Pa., 1881) regards the Venango group as resting immediately upon Chemung flags in Erie and Crawford Counties, Pennsylvania, and is obliged, also, to recognize the fact that the fossils of this group are decidedly of Chemung type. This Venango group is included by Mr. C. A. Ashburner in the Catskill (Ponent, No. IX), but he includes the Bradford oil sands, which were placed higher in the series by Mr. Carll, in the Vespertine No. VIII.

\section{THE PENNSYLVANIA SECTION.}

Without entering into the minutiæ of the extremely interesting series of sections which the Second Geological Survey of Pennsylvania has brought to light, we find a general agreement in the following arrangement of deposits for the UpperDevonian, leaving out the red beds, which must receive special consideration. After passing the Hamilton formation and the black Genesee shale, where they are recognized, there is -

First. A series of thin bedded deposits, generally more argillaceous than sandy, constituting the blue or green shales of the Portage group, containing little or no iron, except in the condition of pyrites.

Second. A series of similar shales, but of generally lighter color and 
weathering brown to yellow from iron oxides, and with occasional thick massive beds of light gray sandstones, often coarse grained and in places conglomeratic, and holding petroleum in some areas. When seen on the surface they are often strongly calcareous, and generally give off a strong bituminous odor upon first fracture.

Third. A series of sandstone conglomerates, with soft shales, not strongly separated from the second group, but the two kinds of rock, the shales and the sands, when interstratified, are each purer in composition, and the iron appears in beds or nodules in the sands, where iron oxides are so frequent as to cause them generally to be of a yellowish tint. Flat pebble conglomerate is seen in some of the beds.

Fourth. The coarse round pebble conglomerate, with thin seams of black shales and true bituminous coal.

\section{THE ALLEGANY COUNTY SECTION.}

In New York I find the Allegany County section bears a general resemblance to the Pennsylvania series. However, in the second group the sandstones are less prominent and the shales prevail, in the socond and third groups the conglomerates are rare and generally only the saudstones are seen, and black shales are interleaved with the shales of the first group nearly to the base of the second. Going farther east in New York, I find the massive sandstones of the second group are reduced to but one or two beds of 2 or 3 feet thickness; and still farther east, but before reaching the Catskill Mountains, this particular class of sandstones is wanting, while the third series, in place of gray sandstones and conglomerates, becomes dark greenish gray, micaceous flags and red shales and sandstones; and, finally, the red and coarse, greenish gray, flaggy sandstones and shales appear still lower and fill the whole interval from the Hamilton shales upward to the Conglomerate.

\section{ORDER OF DEPOSITS IN OHIO.}

Now, turning in the other direction, in Ohio we find a different order of strata. The first group, instead of being followed by the heavier and more frequent sands of the second group, is followed by a return of the condition below, black fine shales and soft greens taking the place of thin bedded shales and sands. And the whole interval of the second and third groups of the areas farther east is represented by only one, at greatest only two, of the sandy conglomerate deposits.

The explanation of this condition of things is to be fully determined only by the fossils. I find that the first group holds a Portage fauna in the soft green shales and a Genesee fauna in the black interleaved shales. I find the second group marked by the departure of the Portage fauna at the first massive sandstones; and with the deposition of those sands of the second group, both in them and in the accompanying shales which are more ferruginous than those below, the Chemung fauna appears. 
With the deposition of the lower flat pebble conglomerates, a new fauna comes in, but it does not entirely take the place of the other fauna. These first conglomerates are clearly shown to be comparatively local, grading rapidly off into coarse sands or even lost entirely in sandy shales in a distance of fifty miles. But their general place in the series is definite and regular in this eastern area. Also, so far as the facts are gathered, it is clear that the faunas associated with them are distinct, even when they were deposited alternately with Chemung shales bearing the genuine Chemung faunas.

In New York the flat pebble conglomerate appeared before the cessation of the Chemung fauna, and in fact we find traces of the latter up to the base of the Olean Conglomerate.

The exact equivalency of the Ohio grits and overlying shales and their faunas must be determined by a fuller and more thorough comparative study of their faunas than has yet been published.

\section{GEOGRAPHIC AND CHRONOLOGIC RELATIONS OF THE FAUNAS.}

It is necessary to recognize the effect of geographical condition upon faunas, as well as the changes incident to chronological sequence, if we would interpret the confusion existing in the Derono-Carboniferous deposits of the eastern portion of our continent. But the assigning of the Marshall fauna to the period of the Catskill group does not settle it. Neither does the expansion of the Chemung to receive the Waverly fauna or the pulling down of the Carboniferous to cover the Portage relieve us from the main perplexities.

It is only by disentangling these faunas and ascertaining the true geographical and chronological relations which they bear to one another that the difficulty is to be met. This is to be attained, not by clinging to any sharp limits of a stratigraphical or a lithological nature or to any absolute division between one formation and the following, but each fauna must be traced upward and downward and its modifications noted until it is replaced by another, and whatever on the way is interpolated or is added to it must be traced to its origin or to its center of occurrence. Thus, I believe, a scale of the chronological sequence in the life history of the organisms and the faunas may be prepared which may serve as a definite standard for determining the relative age of deposits, quite independent of the characters of the sediments which were being continuously thrown down, these being in main part determined by local conditions of the disintegrating shores and the distance away from them. By themselves the rocks, as rocks, present no features which may serve as indications of the particular stage in geological time at which they were deposited.

While the method proposed will make of geology a more difficult and complex study, the entangling of formations and their groups of organisms - inextricably, as it would seem, when the attempt is made to make minute comparisons over wide areas -is much nearer a true ap- 
preciation of the facts as they actually occurred than the simple but concise tabulation of typical series and the co-ordination of those that are not typical by thinning or thickening them with assumed gaps or insertions. The method of critical and careful study of the lithological and stratigraphical condition of the rocks, adopted by the Pennsylvania geologists, is bringing out with great distinctness the untrustworthiness of these characters alone for the co-ordination of horizons over any considerable extent of territory. The study of fossils in their relations to the rock deposits and in their association with one another has already suggested that the sharp lines, often observed separating one group of organisms stratigraphically from another, are in part due to local conditions. As our familiarity with different sections from separated areas increases, the faunas which we shall learn to regard as marking a common geological period or stage will comprise, in some measure at least, groupings of species as various as are now met with in the different regions and at different depths of the sea.

In this report the Upper Devonian, including the Genesee shale, comes under detailed discussion. The lowest member of this section is at Attica, Wyoming County, N.Y. Running northward from there the country is heavily covered with soil and no good exposures of Hamilton rocks are met with, and not till the limestone ridge seen at Batavia is reached have the rocks resisted disintegration sufficiently to present fit outcrops for study. Westward from Attica the Hamilton and the Marcellus are exposed, but all this part of the Devonian is far better represented fifty or a hundred miles farther east.

\section{IIST OF THE FAUNAS.}

The more important groupings of species into temporary faunas are:

The Lingula fauna of the Genesee shales, as seen in section 468 (p. 31); the Cardiola fauna of the Portage shales, $472 \mathrm{C}$ (p. 41); the early Leiorhynchus fauna of the green shales of the Chemung, $476 \mathrm{G}(\mathrm{p}, 60)$; the Spirifera mesocostalis fauna, as seen about Rushford, 476 (p. 58); the Streptorhynchus and Spirifera disjuncta fauna proper, as seen in the Cuba sandstones and similar sandstones to the north, 477 (p. 65); the lamellibranch fauna of a member of these sands, $477 \mathrm{~A}^{3}$ (p. 64); the Lingula fauna in the underlying shales, $477 \mathrm{~A}^{2}$ (p. 64); the Athyris Angelica fauna, particularly represented in the soft shales, $477 \mathrm{H}$ (p. 67); the fauna of the flat pebble conglomerate, 486 (p. 91), and the fauna of the ferruginous sandstone (p. 87).

Besides these there are a few local or special faunas, as a brownish red sandstone above Rushford (p. 56), containing a small terebratuloid shell, which appea's identieal with Centronella Julia, of Winchell, and the special fauna of one of the earliest red bands south of Cuba, with an abundance of a small Orthis Leonensis (p. 67).

Each of these several faunas is distinguishable as a separate group of species, associated with some distinct character of sediment or definite 
horizon. Many of them were probably living at the same time within the same general oceanic area, but one was confined to mud bottom, another to sand, one is peculiar to a black shale, another to a soft green shale, a third to a sandy conglomerate. Several of them may contain a majority of the species alike, but hold some one or more species either peculiar to it or in greater abundance or under some particular varietal form. As we approach the top (it may be in some thin stratum differing from the surrounding deposits) we come across a little colony of a species foreign to the general fauna but characteristic of some formation of a different geographical area, as in the case of Centronella Julia in the Rushford sand (p. 56); or we may find in a series of apparently identical deposits two distinct faunas, having scarcely a species in common, though within a few feet of each other, as in the Lamellibranch and the Brachiopod faunas of the Cuba sandstone (p. 65).

RELATION OF THE FAUNAS TO THE CHARACTER OF THE DEPOSI'S.

By thus disentangling the species and learning their habits of association and their relations to the sediments in which they were buried, the data are gathered for recognizing the faunas in other localities and in deposits where the prevailing lithological character may be so unlike as to give no suggestion of a common horizon.

In the more eastern section, at Caynga Lake and south ward, the black shales are confined almost entirely to the first horizon of the Genesee shale; slight traces of a dark but no black shale are recognized for a few hundred feet above. A rich fauna, the Ithaca fauna, is found in that section before the termination of the Portage fauna, but in its species it resembles both the eastern Hamilton fauna and the true Chemung fauna. The study of its species, and of those occurring above, proves that it represents an earlier stage than that of the Chemung fauna, and that it lies below as well as above deposits containing the genuine Portage fauna.

In the more western section of Wyoming and Allegany Counties the black shales recur frequently above the Genesee shales, and are inter. leaved with the regular Portage shales upward for a thousand feet from their base, each successive stage less distinct and more blended with the contained sediments. This fauna holds on till after the appearance of the Portage shales and its fauna, but becomes less and less apparent with each recurring stage until nothing is left but the Sporangites, which was doubtless an efficient cause of the dark color of the shales. Not a trace is seen of the Ithaca fauna. The Portage shales and fauna and the black shales occur in alternate deposits, the latter prevailing at first and the former being more prominent in the upper part of the series, up to the appearance of the first traces of the Chemung fauna.

The first introduction of the Chemung fauna was associated with the deposition of the gray sandstones generally called Portage sand- 
stones. In their typical display at Portage Falls these sandstones are barren of fossil remains. But in tracing the Portage rocks upward I find a gradual increase in the arenaceous ingredients of the sediments. The Portage fauna belongs to the argillaceous deposits and in the upper part is scarcely ever detected except in some thin streak of soft, green shale interstratified with the more common thin bedded, arenaceous sha!es. The arenaceous shales, by the dropping out of the argillaceons streaks as we ascend, become thin sandstones, which increase in thick. ness, until finally at the top we have thick, massive sandstone separated by barren olive shales. These sandstones terminate the deposits containing Portage fossils and begin the series of the Chemung group. In this section, too, the black shales reach up to them but not beyond. It was clearly shown, by the work of this year, that the Chemung fauna coming in with the gray sandstones is the regular successor of the Port. age fauna, and that the black shales and their special fauna are independent of both and only locally occupy the position in the series here recorded.

Farther to the east the succession of the Chemung fauna upon the Portage is substantially the same, but the black shales had entirely ceased some eight hundred feet below the point of transition.

\section{RELATION OF THE BLACK SHALES TO THE UPPER FAUNAS.}

In the extreme western part of Wyoming County a thin sheet of black shale was found immediately under the first sandstone bearing Spirifera disjuncta, an undoubted representative of the Chemung Brachiopod fauna (sce p. 49); but only a few miles farther east, at Portage Falls, the first sandstones, although following pretty closely the termination of the black shales, contain no trace of the Chemung fauna. We are led to believe, therefore, that with the progress of the Upper Devonian the black shales were gradually withdrawing westward, and that the conditions producing them were independent of the causes producing the argillaceous and sandy shales associated with the Portage and Chemung faunas.

If the same rate of withdrawal of the black shales which is noted on passing from Cayuga Lake to Wyoming County continues on passing farther westward, the black shale should be expected to recur above the equivalents of the Chemung period, or even above conglomerates, as we go westward. That the black shales of Ohio may be such a continuation of the shales occurring in New York was shown by the presence of the characteristic species of the Cleveland shale of Bedford Ohio, in the genuine Genesee black shale of Wyoming County.

As I stated in a preliminary report, an abstract of which has already appeared in Science (Vol. II, p. 836), the identity of the two faunas is not necessarily evidence of equivalency of horizon, but I interpret it rather as a fauna which may have persisted with very little change for 
a long time, possibly during the greater part of the Devonian age, although as yet there is no conclusive evidence that the fauna of the Marcellus black shale was identical with this.

Future study may show the Cleveland shale, at Bedford, Ohio, to be identical stratigraphically with the higher recurrent black shale beds of the Portage of New York, but it is more probable that the fauna persisted with little change, and that the black shales were being deposited continuously (though not continuously in any one particular spot) in the great interior continental basin from the Middle Devonian to the time of the sub-Carboniferous limestones. Another fact brought out by these studies is that the sandstones, as we pass upward from the time of the reign of the Hamilton faunas, changed gradually from thin argillaceous sandstones or arenaceous shales of a dark color and flaggy structure, first to thicker beds with less clay, then into purer and more massive sandstones with slightly coarser grain and of a lighter gray. without fossils; and, higher, become light gray sandstones, calcareous and generally fossiliferous, with the Chemung fauna, and, pretty generally, more or less saturated with petroleum.

The petroleum odor of those outcropping on the surface is proportionate to their porosity and freedom from lime.

PLACE OF THE VENANGO OIL GROUP.

From a study of Mr. I. C. White's sections of Erie and Craw ford Counties, as given in Report QQQQ, Second Geol. Surv. Pa., it seems more than probable that his Venango oil group is identical with these Chemung sandstones. Comparison of their fossils alone can give conclusive testimony on this point. Mr. White's opinion is that the Panama conglomerate is equivalent to the third oil sand of Venango group (see QQQQ, Second (teol. Surv. Pa.).

Mr. Carll (in Report IIII, Second Geol. Surv. Pa.) still refuses to accept this interpretation, but he makes no positive identification and even suggests a plane of non-conformity. If the method adopted by the Pennsylvania survey were capable of solving this intricate problem, the careful and most industrious study given their rocks should have brought a more satisfactory solution than we at present have. It would be difficult to improve upon the stratigraphical data already accumulated.

If fossils prove as satisfactory in the more western deposits as they have proved in the New York Chemung they should decide, when carefully studied, whether a portion of the series is missing or whether the geographical change alone is to account for the changed faunas. But I reserve opinion until I can compare the fossils themselves and learn their associations.

\section{STRATA FOLLOWING THE CHEMUNG FAUNAS.}

Above the Chemung sandstones appear coarser sands with occasional streaks of worn pebbles, the larger sizes of which are flat and of a still 
lighter gray color. They show decided traces of iron in the higher berls, each bed beginning or terminating, or both, with ferruginous beds composed of clay ironstone nodules in the midst of the sand. As these ferruginous sandstones are reached the. Chemung fauna comes to its close and another series of deposits becomes dominant, which, in their purity, contained no marine faunas. They took the place of the Chemung series, but are not sharply distinct at the outset.

In the Allegany County section this new series of rocks began down among the deposits containing the Chemung faunas, first as thin streaks of red argillaceous shale, a little below the first gravel sandstones and ferruginous sandstones and conglomerates, and, at the stage of the latter, the red beds were of frequent occurrence, but rarely over a foot in thickness. These red beds were apparently the continuation, under changed conditions, of the olive shales of the Chemung, which contained a fauna differing in the characteristic species from the sandstones interstratified with them. At first the red beds held a few of the species of that fauna, but soon lost them and were utterly barren at every later stage of their recurrence.

Interstratified with the red, argillaceous shales and apparently taking the place of the sands occurring below, we find rather coarse, micaceous sandstones, generally very evenly bedded, the mica grains sometimes mingled intimately with the sand, causing a loose mealy structure; at other times the mica grains, almost pure, are laid out in thin sheets, making an imitation of schistose structure or forming very even, thin flagging. These micaceous sandstones have no fossils and are of a gray green to a dark green color, and when weathered are of ten peppered with dark brown spots, from the decomposition of minute ferruginous grains.

As we pass upward the red shales are more frequent and some layers become arenaceons, so that the mass of the deposits is of alternations of red argillaceous shales, red arenaceous shales and sandstones, and green micaceous sandstones and shaly sandstones.

At this stage some of the beds of olive sandy shale, with fewer and smaller grains of mica, contain large scales of Holoptychius and other fish remains, and ferruginous sandstones occur, with a restricted marine fauna which appears to be the successor of the Chemung fauna; and, finally, to close the series, a thick massive conglomerate appears, which, in this region, is called the Olean Conglomerate, composed of coarse silicious sand and coarse, rounded, but little worn, often large sized quartz pebbles.

It will be seen, in this brief review of the series of deposits, that the red and green shales and sands which take the place of the Chemung group and occupy the interval between it and the Olean Conglomerate are the equivalents of those thick deposits which form so prominent a feature in the eastern part of New York State and extend southward across 
Pennsylvania, \&c., where they are known as the Catskill group. They are feebly represented in the western part of New York, where the Upper Devonian is best represented. The thick deposits containing Devonian plants at St. John, New Brunswick, and in the northeast, are undoubtedly a northern extension of the same series, although beginning at a much earlier stage as measured by the progress of marine faunas.

In regard to the Catskill group, my studies have led me to believe that the Catskill red rocks of the east offer evidence of having been contemporaneous with a great portion of the Upper Devonian rocks, and a comparison of faunas, at least, goes to show that the base of the red beds does not form a definite and uniform horizon. Influenced apparently by the contrary opinion, Professor White makes a provisional upper limit for the Chemung group of Columbia County, Pennsylvania, at the lowest red rock, and calls the interval between this point and where the Holoptychius appears the Chemung-Catskill. (See Second Geol. Surv. Pa., G7, p. 63.)

\section{THE INTERPRETATION OF THE FACTS.}

Taking the faunas as our criteria of chronological horizon, it seems more appropriate to speak of the red beds as appearing farther down in the Chemung group than to make a break in the series long before any permanent effect was produced upon the character of the faunas.

The interpretation given by the English geologists of the Devonian and Old Red Sandstone series is relevant here. The Old Red Sandstones, with their brackish water fish fauna and plants, are not successors of the Devonian beds with marine fanna; but are the equivalents of the whole series from the base to the top of the Devonian.

The Russian series clearly illustrates this point. Alternation is there seen of the two classes of deposits, the one containing the Devonian marine fossils, the other the sandy brackish water beds with the Holoptychius, even in association with the marine brachiopods of Upper Devonian species.

As we follow our Devonian series eastward, either in New York or in Pennsylvania, the lower position of the first red beds is conspicuous, and so long as the red sediments occupied the ground only temporarily we may suppose the marine conditions were not entirely cut off, and slight oscillations drove away and brought back the marine fauna over any particular area, but when the marine conditions were finally shut off there was a termination of the marine fauna. This shutting off of the sea took place earlier in the eastern than in the western part of this New York-Pennsylvania area, and there is reason to believe that in Sullivan County, New York, it was as early as the reign of the Hamilton faunas. (This was shown to be a fact in Chenango and Otsego Counties by in. vestigations in 1885. Communicated to Am. Asso. Adv. Sc. meeting at Ann Arbor, Sept., 1885.) 
The Holoptychius evidently found its congenial habitat in the midst of the red rock conditions. Its occasional appearance in strata below the termination of the Chemung fauna is rather confirmatory evidence of the actual presence in other geographical areas of those conditions from which the specimens strayed than evidence of any higher horizon than that indicated by the same fannas elsewhere.

In the Western New York area the gradual appearance of Catskill deposits was due to the encroachment of the land and fresh water conditions upon the marine basin in which the Chemung faunas flourished. The Chemung faunas continued to live there so long as the marine con ditions were sufficiently pure to maintain their life, and I take it that there is nothing inconsistent in the view that Catskill rocks were being deposited in the Appalachian region at the same time that Chemung rocks were being formed over Western New York areas and during the reign of the Chemung faunas.

As the fossil faunas were traced upward in their successive stages, it was ascertained that, besides the changes occasioned by the dropping out of some species and the introduction of new species, the decreased abundance of common forms, or the increased abundance of others, there was also a change in the dominant varietal modification of the more common forms. Detailed report of these modifications coincident with range and distribution will be more satisfactory after a wider territory has been examined and a fuller series of species and specimens has been brought into comparison. But already some general remarks can be made as to the kind of changes detected.

In one species, Spirifera mesocostalis, ranging from the base of the Ithaca group high up into the Chemung, a great modification of form and size was observed. The prevailing type, at its earliest appearance, was small and with fine mucronate extension of the area; the later type, which was more abundant in the western than in the eastern section, was large and coarsely plicate, with great extension of the front, and, though with short mucronate hinge area, this feature is not prominent and this dimension of the shell is prominently short. Moreover, while the later modification is wanting in the earlier fannas, the earlier type still exists in the later faunas, but is relatively rare. A study of the species from a wider geographical territory will be required in order to determine how much these modifications are the effects of geographical conditions.

One modification of this species was found to be entirely coincident with geological range in the collections at command. This is the gradual appearance and final prominence of a median keel dividing the muscular impressions within the beak of the ventral valve. As this is one of the characters distinguishing the genus Spiriferina, it is interesting to note its gradual assumption as a purely varietal character of an undoubted spirifera. This character is represented in Figs. 10 and 11 of Plate 40, Geol. Surv. N. Y., Pal., Vol. IV, Pt. I, and slightly in Fig. 2. 
I have examined a large number of specimens, but among the earlier representatives from the Ithaca group rarely is even a trace of this character seen; an occasional specimen, however, shows a slight ridge dividing the muscular impressions. In the higher beds it takes the form of a strong median septum, but is less prominent in the small form associated with the prevailing type, but rare at that particular stage. Other representatives of the genus presented traces of the septum at an earlier stage.

Another change in type associated with the geological range of the species is seen in the case of Orthis impressa. In the lower part of the Upper Devonian (base of the Ithaca group) it differs little from the round, narrow form of $O$. Tulliensis; in its later stage it is particularly wide at the front, with a wide, pronounced fold and sinus, and of large size.

The Lingulas of the black, and later greenish, argillaceous shales present a regular series from the minute Lingula spatulata of the black Genesee shales, through intermediate forms, to the typical Lingula Melie of the Ohio black shales. In this area the larger form is attained at an early stage of the Upper Devonian faunas.

So far as at present observed, these varietal modifications of a specific type are at first represented by a few rare forms in the midst of abundant individuals of the typical form; and as we go upward the characteristic feature becomes conspicuous by being assumed by a greater proportion of the individuals of the species, and finally becomes the prevailing form, the original type then appearing only as an occasional variation.

A few facts brought out in the course of these studies may be noted in closing this chapter.

The vertical fucoid markings, as they are called, in the Portage sandstones and similar sandstones above, are evidently the borings of some kind of worm or boring animal; and these markings, whatever they were, characterize the Chemung sandstones of the Allegany County section up to the conglomerates of flat pebbles. Above this point, and often in the sandstones associated with the flat pebble conglomerates, a similar marking is seen in some of the sandstone layers; but the size of the boring is always smaller and shorter, generally about half as large in diameter, and the borings are arranged much more closely together. So that, although the organism forming them may have been of a similar nature, the upper one was undoubtedly of a distinct species. This fact, we think, may help in tracing the horizon of the upper fucoid-bearing sandstones (as a name for which I would suggest Verticalis sandstones) toward the west, where the fossils are rare.

Also, on comparing our Allegany section with those of McKean Conuty, Pennsylvania, it appears more than probable that what Mr. Ashburner calls the sub-Olean conglomerate is the equivalent of the 
ferruginous sandstone, which approaches very near the base of the Olean conglomerate, both at Olean and at Little Genesee, rather than the Allegany County flat pebble conglomerate, which is, more likely, represented at a similar position at Bradford below Holoptychius beds, but above the appearance of the Chemung faunas, and, on Mt. Raub, was recognized some three hundred feet below the Conglomerate in the outcroppings on the surface.

At Hornellsville, about half way between the Western New York section and that running through Ithaca, in Tompkins County, was seen a remarkable confirmation of the hypothesis advanced in regard to the position of the Ithaca fauna. Here was found exposed a section at the point of transition from the Portage to the Chemung fauna. The gray shales carrying the Portage fauna are preceded by a streak of black shale like the last representatives at Portage. With the Portage Cardiola fauna was found the first Chemung stage of Spirifera mesocostalis, with an Orthis, not the species common in the more western section, but the Orthis Tioga of the "Chemung" of the Cayuga meridian. Immediately following the Cardiola fauna, in shales more sandy and ferruginous in character, was seen the fauna of the lowest Chemung at Rushford, the Leiorhynchus fauna, with the exception that the eastern Orthis took the place of the common form of the Allegany rocks. This was followed above by more sandy deposits, containing the typical Chemung faunas. The altitude and the rocks exposed along the railroad all the way to Elmira leave no doubt of a position stratigraphically between six and eight hundred feet above the horizon of the Ithaca group at Ithaca. The transition from the Cardiola fauna directly to the lowest Chemung fauna is also unmistakable, and the OrthisTioga is evidence of the genuine Chemung fauna of the eastern section as distinguished from the lower Ithaca fauna.

It furnishes evidence, therefore, that the transition from the Portage to the genuine Chemung formation is far above the Ithaca group, and that the fauna of the latter is an earlier stage, and intermediate between the Chemung and the Hamilton, and has no representative in the aection in Wyoming and Allegany Counties. 


\section{CHAPTER II.}

FAUNAS OF THE GENESEE SHALE AND THE PORTAGE GROUPS.

The exposures of the Genesee shale are noticed first, on going southward, along the northern line of Wyoming County, and most of the exposures in the middle and southern part of the county are of the Portage group.

These include the following stations: 468 Attica, 471 Warsaw, 472 Varysburg, 473 Bennington, including $473 \mathrm{~A}$, the Daubree quarry, and $473 \mathrm{~B}$, the section at Sierk's station, and 475 Java.

Attica, Wyoming County, N. Y.-468.

Attica is situated $\mathbf{1 0}$ miles a little west of south from Batavia. After leaving the limestone ridge there are few if any good exposures of rock directly south until near Attica, where the first traces of the Black Genesee shale appear.

The Tonawanda Creek runs directly through the town of Attica, but below this point it runs through clay and gravel banks until reaching the limestones of the northern towns. The creek is dammed just uuder the railroad bridge; the altitude of the railroad at this point is about a thousand feet (998) above the sea. The bed of the creek below the bridge is black shale - a fine exposure of the Genesee shale. The dam covers its top, but, taking the railroad bed as a datum, I estimate that the top of the Genesee shale at this point is not far from 975 feet above tide level.

The bottom is not exposed; hence the thickness cannot be given.

Several exposures were examined in and about Attica, giving sections $468 \mathrm{~A}, \mathrm{~B}, \mathrm{C}, \mathrm{D}, \mathrm{E}$, and F. A combination of these several sections gives us a very fair representation of the general character of the base of the Upper Devonian for this region.

The Genesee shale is a black bituminous shale, when freshly broken giving out a strong odor of petroleum, and with dark brown scratch. It is very evenly bedded, compact, and when fresh from the quarry is massive, with a conchoidal fracture. Upon weathering it becomes more fissile, but is generally a very fine uniform shale, withstanding the weather a long time without showing tendency to fissile cleavage. It is seen best in $468 \mathrm{~B}$. The fauna of this exposure $(468 \mathrm{~B})$ of the Genesee black shale is as follows:

Lingula spatulata, varying from the minute, sharp beaked form characteristic of the Genesee shales to the wider, more oval form of the Cleveland shales, Bedford, Ohio, called L. Melie and L. subspatulata by Ohio paleontologists. 
Sporangites, the same forms as those of the Ohio black shales.

Conodont teeth, identical with and including the majority of forms figured by Professor Newberry in Rep. Geol. Surv. Ohio, Vol. II, Pt. II, Pal., Pl. LVII.

\section{Palceoniscus scales.}

This fauna, therefore, agrees closely with that of Professor Newberry's Cleveland shale of Bedford, Ohio. The broader variety of the Lingulas is not only plainly a mere variation of the typical Lingula spatulata, but is quite indistinguishable from specimens of the Lingula of the shales at Bedford, Ohio, with which I have carefully compared it. The Bedford specimens are generally of larger size, but those of the same size agree in form, convexity, and surface markings for the two localities.

In the olive shales underlying the Cuba sandstones are seen Linguias which agree also in average size with the ordinary $L$. Melie of Ohio.

The close agreement in the species and in the combination of species in these two zones leads us to the opinion that we are dealing with the same fauna in the black shales of Genesee in New York and at Bedford and Chagrin Falls in Ohio, although the evidence has not appeared to prove that the horizons themselves are synchronous.

The Genesee shale is followed by a soft argillaceous green shale, with Portage fossils. Toward the upper part there are some calcareous layers and an occasional thin layer of arenaceous shale. Then comes a second black shale, which is again followed by greenish shales; this by another black shale, and so on for at least several hundred feet.

It is an oscillation between two principal types of deposit, each of which becomes gradually modified in the same way as we ascend the series:

First, the black shale in its pure condition seen in the Genesee shale.

Second, the green argillaceous shale characteristic at the base of the Portage.

These two alternate with each other, and with each change, as we ascend, the green shale increases and the black shale decreases in amount. The black shale at each stage of its reappearance is more arenaceous, assumes a decided iron stain upon weathering, and also weathers quickly to fine fissile chips, which, in the lower beds, long resist further disintegration, but in the upper beds have not the power of resistance and soon are reduced to soil. In the first reappearance of black shale above the Genesee shales there is still a strong petroleum odor upon fresh fracture, and when fresh from the quarry the appearance of the shale is black, massive, capable of conchoidal cleavage, and scarcely distinguishable from the Genesee shale below. But upon weathering it quickly reveals the presence of inequality in the minute constitution of the deposit, causing it to cleave into thin flakes. These first Portage black shales exhibit their relation to the Genesee shales below by the presence of the same fossils. 
Lingula spatulata was taken from the black shale fully 100 feet above the Genesee shale, separated from it by the green argillaceous shales with a characteristic Portage fauna.

Higher up the black shales rarely contain a single fossil. The green shales show the same gradual change from soft, fine, argillaceous material to coarser, more arenaceous, and more irregular strata ; in the upper part the sandstone masses are interstratified with the softer argillaceous shales. There is also a change in the color; the lighter green shales are more prominent in the lower part, and the black shales lose their color on going upward, till finally they are scarcely distinguishable from the accompanying arenaceous shales of the Portage group.

$468 \mathrm{D}$ is a cut in a gorge southeast of the village of Attica, about two miles distant. The first rock exposure of the cut is, approximately, 1,200 feet above sea level. Stratigraphically it begins somewhat above the top of $468 \mathrm{U}^{3}$, perhaps over 100 feet. But $468 \mathrm{E}$ is below its base and represents the intervening part of the section, although it is difficult to determine the precise equivalency of the individual strata in the several ravines. The strata are composed of alternating masses of black and soft green shales. The lower part of the series presents thicker masses of black, and as we go up the black shales are less strongly marked, more arenaceous, and each succeeding mass is thinner than the preceding.

The cut $468 \mathrm{D}^{1}$ to $\mathrm{D}^{11}$ represents something over 200 feet of strata and at the top the green shales entirely replace the black. $D^{2}$ is the lowest seam of black shale in this cut; it is very similar lithologically to the first black seam above the true Genesee shale and is but a few feet thick; its termination is not exposed, but when the next exposure appears in the bed of the stream it is the gray green shale again; it contains Sporangites and Palceonicus scales, but no Lingulas or Discince were discovered. $\quad D^{4}$ is a gray shale, rather massive and hard, followed by a second black shale containing Sporangites. A little higher, $\mathrm{D}^{5}$, gray shales predominate, but with thin layers of dark shale, not so black as those below; but along in this part of the cut, for 100 feet, the light gray green shales carry sporangites and Styliola, the former very dis. tinct in the light colored strata. . In $D^{6}$ are some soft, argillaceous, light gray green shales, still showing traces of Sporangites. Styliola also appears in the soft, light shales at $D^{7}$. At $D^{8}$ the thin black layers are conspicuous again and hold Sporangites, but the gray soft shales prevail and carry the same fauna. At $\mathrm{D}^{9}$ the black layers have disappeared, and from this point upward only dark bluish strata alternate with the prevailing gray green shales. In the darker parts Sporangites are occa. sionally seen. With the ceasing of the black streaks the Portage fauna begins to reappear. Small aviculoid shells and Cardiola speciosa are the first to be recognized at $\mathrm{D}^{9}$, with styliola. At $\mathbf{D}^{10}$ the shales are light olive in color and soft, argillaceous, and quickly weathering into soil; in this stratum Cardiola speciosa is conspicuous; Pterinopecten

Bull. $41 .-3$ 
Atticus, n. s., Leperditice, the broad variety of Lingula spatulata, a small imperfect Pleurotomaria, a crinoid stem half a centimeter in diameter, and a minute Chonetes lepida constitute the fauna, so far as discovered. A little higher, $\mathrm{D}^{103,}$, the shales are decidedly arenaceous, and from there to the top of the gorge the shales are harder and coarser and the olive tints are replaced by bluish and darker grays. At $\mathrm{D}^{11}$ Cardiola speciosa appears with a Hyolithes and Goniatites and some new forms. All the species of this cut are small, delicate forms, and are nowhere abundant, but require very close, careful search for their discovery. Enough, however, was found to demonstrate the general relation of the faunas to the deposits containing them.

It is evident, from a study of this series in connection with $468 \mathrm{~A}, \mathrm{~B}$, and $\mathbf{C}$, that the deposits from the base of the Genesee shale, for several hundred feet at least, are the result of oscillating, conditions which brought from one direction the black muds, highly bituminous in nature, and from another direction light gray muds, at first very fine and argillaceous and later mixed with coarser, silicious particles.

The Palconiscus scales are peculiar to the black shales. The Sporangites, although characteristic of the black shales, are not confined to them so long as they were in the neighborhood, as is shown by their occurrence in the light, argillaceous shales interstratified with them, but when the black shales finally withdrew from this locality the sporangites ceased.

The Lingula spatulata is peculiar to the soft, argillaceous deposits, most abundant in the bituminous shales, and there typically represented; in the light colored shales only the broad and larger variety appears.

The other species, the Cardiola speciosa, the Aviculas, the Pleurotomaria, the Chonetes, the Leptodesm a, the Hyolithes, and the Goniatites, belong to the fauna of the gray shales, rare in the pure, argillaceous sediments, but more abundant as the silicious and coarser muds were depositing.

Leperditia and Styliola may have been common to both faunas; the former was rare. Other evidence shows the latter to be more abundant in the black shales.

\section{The Cardiola Fauna-468 A.}

The following species, have been identified in the soft, argillaceous shales at the base of the Portage:

Cardiola speciosa, ${ }^{1}$ abundant.

Styliola fissurella, abuudant in some layers.

Goniatites uniangularis Conrad several specimens, small.

Goniatites complanatus.

Lunulicardium fragile.

Lunulicardium levis, $\mathrm{n} . \mathrm{sp}$.

Coleolus acisula.

:The generic name Glyptocardia has been proposed for this well known species by Professor James Hall (1885). (See Pal. N. Y., Vol. V, Pt. I, Lamell. II, p. xxxv.) 
Sporangites, rare.

Lingula spatulata, the broad variety, a single specimen.

Pleurotomaria? capillaria, fragments.

Leperditia, sp., a few impressions.

Aptychus of Goniatites? of G. uniangularis.

Aptychus? or Spathiocaris? (Clark), fragments marked like S. Emersoni, but broken so that the shape is not shown.

In similar shales, but calcareous $\left(\mathrm{C}^{2}\right)$, there are, besides the Cardiola, Calceola, and Styliola, which are the more frequent forms, a small Orthoceras and a Palceoniscus scale of larger size than those in the black shales; in another exposure, a small Loxonema? not preserving the exterior, but resembling the terminal portion of $L$. delphicola. The Styliolas often occur in elongated masses, which weather a yellowish brown from iron stain, and the shape of the masses suggests a possible coprolitic origin.

\section{DESCRIPTION OF TWO NEW LAMELLIBRANCHS.}

Pterinopecten? Atticus, n. sp. Plate III, Figs. 10, 11.

This is a small species, with subquadrate form, hinge line straight and shorter than the greatest width of shell, ears small and indistinctly defined. The middle portion of the surface marked by irregular, rounded, radiate folds or plications, which bifurcate and are more conspicuous toward the front; the sides are either smooth or faintly marked by fine radiate striæ. Concentric lines of growth are apparent over the whole surface, but not strong. The beaks are prominent, slightly arching over the hinge margin. The wing is not produced into a mucronate point, as in most of the Pterinopectens, nor is it shortened, as in the Lyriopectens. The anterior ear is separated by a rounded sulcus and fold, but is not sharply defined. The posterior wing is much as in Lyriopecten.

Dimensions of medium sized specimen: Length, $\mathbf{6 . 5 ^ { \mathrm { mm } }}$; width, $\mathbf{5 . 4} \mathbf{m}^{\mathrm{mm}}$.

Horizon and locality: The soft, green shales, Middle Portage group, Attica, N. Y.

Specific name from Attica: Lat. atticus, dwelling in Attica. Ptychopteria? mesocostalis, n. sp. Plate III, Fig. 9.

A small pterinoid shell, oblique, similar in form to some of the smaller shells of Hall's genus Ptychopteria (see P. Proto., Geol. Surv. N. Y., Pal., Vol. V, Pt. I, Pl. XXIII, Lamell. I), but marked across the middle by irregular rounded radiate folds, the sides by faint and finer radiate striæ. The anterior wing separated by a sulcus and fold, the posterior wing moderate, without mucronate extension, the ventral margin slightly concave and posteriorly broadly rounded into the posterior margin. With concentric rounded lines of growth.

In its details this shell is marked almost exactly as the erect forms, found in the same rocks, which I have called Pterinopecten Atticus. Ido not find intermediate forms. The only definable difference could be ac- 
counted for by the development of this shell more obliquely and rapidly in the direction of its umbonal ridge.

I am constrained, after much study of the material at hand, to regard the specimens, like Fig. 12, as a smoother and extreme variety of this species, although this would be more appropriately called a Leptodesma, except for the radiate striæ of the surface. These three forms, figured as $9,10,11$, and 12 of Plate III, could be taken as types of three species, and even three distinct genera if we were to follow some of the modern usages in describing them. While I refer them provisionally to two distinct genera I believe that they are closely allied, and that they should all be included in the same genus, but that genus is neither of those named as they are now defined, but should be bounded by different characters. The present classification of Pterinea Goldfuss into the genera Actinopteria and Ptychopteria on the one side and Leiopteria and Leptodesma on the other, used in the fifth volume of the Palæontology of New York, leaves practically no characters for the differentiation of the species concerned, except those of contour and general form, and whenever I have seen these species in abundance in the same locality the variations in both of these particulars are so considerable that it is difficult to believe that the division into so many species as are defined is either judicious or will be of any use to science further than giving a thorough illustration of the plasticity of this type of shells. At a future time $I$ hope to discuss this subject more fully.

\section{Warsaw, Wyoming County, N. Y,-471.}

This station is ten miles southeast of Attica (468) and nine miles east of Varysburg (472). The town is in a valley with hills, both east and west, rising over three hundred feet. The altitudes are, for the New York, Lake Erie and Western Railroad station, 1,326 feet above tide; for the Buffalo, Rochester and Pittsburgh Railroad, on the west side of valley, 1,117 feet above tide. The post office is reported by surveyors of the place to be 1,017 feet above tide. The hillsides are cut by several ravines, exposing two or three hundred feet of rock outcrops.

Crystal Brook, Warsaw.-471 A.

This ravine cuts down the hillside a little northeast of the village. The first rocky exposures may be 1,050 feet above tide, and they were examined upward about two hundred feet, to the first solid sandstone under the New York, Lake Erie and Western Railroad, at an altitude of approximately 1,250 feet.

The whole exposure is composed of thin bedded deposits of argillaceous and arenaceous shales, with occasionally a stiff, thin seam of flaggy sandstone. The prevailing colors are blue gray near the bottom; the softer, more fissile shales are more greenish or olive. The general characters resemble very closely those of $468 \mathrm{D}$, with the exception of the absence of black shales. No sandstone strong enough to form any con- 
siderable fall is met with till we reach the top, and this seam is gray, but finer, harder, and more flaggy than the typical Portage sandstones. It is, however, calcareous. No traces of the Verticalis borings were seen. Underlying it are some soft, greenish shales, some layers of which are nodular. Under these are darker blue shales bearing the same fanna found in the upper part of $468 \mathrm{D}$.

Omitting the consideration of the black shales and comparing the general character of the deposits and their fauna (that is, the olive shales gradually changing into bluish and more arenaceous deposits, with flaggy and wave marked structure, as we ascend), I should regard the base of this section as occupying a stratigraphic position somewhat higher than the top of section $468 \mathrm{D}$.

The aviculoid shell Pterinopecten Atticus, abundant at $468 \mathrm{D}^{10}$, at an altitude of 1,340 to 1,350 feet, is identical with the species most abundant in the Warsaw station 471, at an altitude of about 1,200 feet. The following 100 feet of the Attica section (468 D) takes us up to sandy and flaggy deposits; in the same way the upper deposits of 471 are sandy and flaggy, following soft, light colored shales.

The species of $471 \mathrm{~A}^{3}$ are -

Cardiola speciosa, abundant.

Lunulicardium levis, $\mathrm{n}$. sp.

Styliola fissurella, rare.

Pterinopecten? Atticus, n. sp., abundant.

Ptychopteria? mesocostalis, n. sp.

Sporangites, rare.

Euomphalus ?, a fragment.

Goniatites uniangularis.

Fragments of crinoid stems.

Coleolus ?acicula.

Aptychus of Goniatites. Plate III, Figs. 3 and 4.

The specimens figured are of a small, thin, scale-like fossil, black when the substance is preserved, and app arently chitinous originally. In outline it has the shape of a transverse section of the outer chamber of Goniatites, like G. bicostatus, and of the same size as would fit such specimens as have beep found in the same horizon.

The shorter specimen (Fig. 4) may belong to a more closely coiled species, like G. uniangularis, which also is found in the same rocks.

The more perfect specimen (Fig. 3) is $8.3^{\mathrm{mm}}$ long, $5.2^{\mathrm{mm}}$ wide, and the depth of the rounded sinus is $2^{\mathrm{mm}}$. This is supposed to represent the greove formed by the inner coil of the shell partly inclosed by the outer lining chamber. The Aptychus is not flat, but transversely arched, the arching confined to the central portion, and marginally it is nearly flat. I find no reason to doubt that this was an Aptychus of one of the Goniatites so frequent in the Portage rocks, and in size and form it agrees very closely with the figures in Keyserling's Wiss. Beob. Reise 
Petschora-Land, Pl. 13, Figs. 3-7, and referred by him to Aptychus (see pp. 286, 287, and Fig. 5 particularly). The specimens were from the concretions in the Dominick black shales. It is one of the same class of objects referred to Cardiocaris by H. Woodward, Geol. Mag., London, vol. 14, p. 386, and to Spathiocaris by J. M. Clarke (Am. Jour. Sc., Vol. XXIII, 3d ser., p. 477). The recent discoveries of Kayser, Dames, and Woodward leave no doubt of the Aptychus nature of some of the so-called phyllopod crustacea of the Silurian and Devonian.

The specimens here figured are of the type called Anaptychus by Offel and belong to the group Simplices of Zittel's classification (Palæont., Vol. I, Part 2, p. 403), consisting of a single piece. It is probable that all the forms from the Portage rocks described by J. M. Clarke as Spathiocaris and Cardiocaris, and possibly some other genera, are of a similar nature. (See Dames, Zeitschrift d. deutsch. geol. Gesellsch., 1882, Vol. XXXIV, p. 819 ; Neues Jahrbuch, Bd. I, 1884, p. 178; and Woodward, Geol. Mag., Dec. III, Vol. II, 1885, p. 345, and Plate IX.)

\section{Lunulicardium Munster.}

Several specimens from the green shales of the Lower Portage group are referred, after considerable study, to the genus Lunulicardium as restricted by Zittel (Handb. d. Paleont. Vol. I, Part 2, p. 36) and as applied by Hall (Geol. Surv. N. Y., Pal., Vol. V, Pt. I, Lamell. II) to such forms as Avicula fragilis Hall of the Geol. Report, 4th dist. N. Y., p. 222.

Thï specimèn figured on Plate III (Fig. 7), on careful comparison with geninine examples of $L$. fragile from the Marcellus shales and higher, is found to be indistinguishable, except in its more gibbous form, which is ascribed to its better preservation through the possession of a thicker shell. The typical forms of $L$. fragile were evidently very thin and are found in the fossil state crushed very flat, but always with more or less wrinkled surface. These Portage specimens occasionally show fine radiate striæ on the surface, a character recorded as appearing on well preserved specimens of $L$. fragile.

In the more oblong forms (Plate III, Figs. 5, 6, and 8) the fine radiate striæ are pretty generally visible upon magnifying the surface, and the position, length, and direction of the byssal fissure are those of $L$. fragile. In one specimen (Fig. 8) the lip of the byssal gap is reflected, as in well preserved specimens of $L$. fragile, but in another specimen (Fig. 6) of the opposite valve the lip of the opening is inflected, as in some of the Limas. The latter appears to be a right valve and the former a left valve.

In each of the oval specimens opposite the byssal opening is a very small angular extension of the cardinal margin, upon which are two or three sharp radiating plications or lateral cardinal teeth. In this feature they recall such forms as Mytilarca (Plethomytilus) oviformis Hall of the Hamilton group (Geol. Surv. N. Y., Pal., Vol. V, Pt. I, Lamell. II, PI. XXXI, Figs. 7 and 8), but the direction of growth and the curvature 
of the shell and direction of the beak are distinct. The cardinal angle is also much more prominent in that species. While there appears reason for regarding the shells under consideration as allied to the Mytilarcas, as may possibly be also the $L$. fragile, taking all points into consideration they fall more naturally under the genus in which $L$. fragile is found.

I propose for specimens figured on Plate III, Fig. 6 and Fig. 8, the name Lunulicardium levis, and refer provisionally to the same species the larger form, Fig. 5 .

\section{DESCRIPTION OF LUNULICARDIUM LEVIS.}

Lunulicardium levis, n. sp., Pl. III, Figs. 6 and 8.

Shell medium size, obliquely oval, with sharp, short beak nearly central, with byssal gap starting close under the beak on the anterior side and reaching obliquely about one-half the length of the shell, lip reflected in the left valve and inflected in right valve, the front broadly rounded and curving around regularly to near the beak on the posterior side, where is a slight angular extension of the hinge margin, upon which are two or three well defined radiating plications which may be lateral cardinal teeth. Surface nearly smooth, with concentric lines of growth and very fine, radiate striæ.

Dimensions: Length, $20^{\mathrm{mm}}$; width, $15.2^{\mathrm{mm}}$; length of byssal fissure, $12.9^{\mathrm{mm}}$; angle of byssal lip with central axis of shell, $40^{\circ}$ to $41^{\circ}$.

Horizon and locality: The green shales of the Lower Portage group at Varysburg and Warsaw, Wyoming County, N. Y.

Varysburg, Wyoming County, N. Y. -472.

At Varysburg three sections were examined, $472 \mathrm{~A}, \mathrm{~B}$, and $\mathrm{C}$. The position of this station is about seren miles south and a mile or so west of the Attica station 468. The altitude, estimated by railroad grade, is 1,239 feet above tide level. The bridge across the Tonawanda Creek in the valley is approximately 1,121 feet above tide level. Along the banks of the stream some thick layers of black shale appear, with interstratified masses of the olive Portage shales. But we are here near the top of the black shale deposits, the highest traces of which were $472 \mathrm{~B}^{5}$ at 1,270 feet and a thin streak in section $472 \mathrm{C}$.

These are not pure black shales, but contain particles of pyrite and mica mingled with the arenaceous particles of the including strata, and they show traces of Sporangites. $472 \mathrm{C}^{0}$ is a more massive black streak of the same shale, several inches thick; by its physical characters it is evidently one of the last of the recurrent deposits of the black shale. $472 \mathrm{~A}$ and $\mathrm{B}$ are sections on the west side of the valley, while the section $\mathrm{C}$ runs off to the northeast along the gorge of Stony Brook, and traverses 160 feet of strata, the top sandstone $\mathbf{C}^{6}$ reaching an altitude of 1,345 feet approximately. 
$472 \mathrm{~A}$ is an imperfect section directly west of the village, traversing about the same strata as those seen in B.

The sandstone in the midst of this section is apparently the same that is worked in the quarry at $472 \mathrm{~B}$ and met with again in the section $\mathrm{C}$ at $\mathrm{C}^{3}$. Above this sandstone no black shales have been seen. In section A it is several feet thick, massive, calcareous, of a gray color, weathering brownish gray, fine grained, and hard. It contains in the upper layers the perforations called Fucoides verticalis in the State reports.

The sandstone is followed by irregular layers of thin sandy shales and thicker olive shales, not fissile, but blocky in fracture and of rough surface, and in places nodular, the nodules about the size of hickory nuts and calcarceous; the shale is also slightly calcareous. A few fossils were found in these olive shales, but in a poor state of preservation.

The fauna determined is as follows:

Cardiola speciosa.

Lunulicardium levis, n. sp.

Goniatites complanatus.

G. bicostatus.

Lucina Wyomingensis, $\mathrm{n}$. sp.

Lucina Varysburgia, n. sp.

Orthoceras (frag.).

Pleurotomaria (frag.), (? P. capillaria).

Orinoid stems.

All rare, but the Cardiola and Goniatites are more common.

Quarry of the Tonawanda Valley and Cuba Railroad - $472 \mathrm{~B}$.

This quarry is west and about fifty feet above the station of the Tonawanda Valley and Cuba Railroad at Varysburg. The top of the ledge from which quarry stone is worked is 1,292 feet above tide.

The upper course is two feet thick, with a tendency to divide into two one foot courses. This is $472 \mathrm{~B}^{1}$. It is a light olive gray, massive sandstone, calcareous, and perforated in the upper part by numerous tubes of the so-called Fucoides verticalis; these are filled with the darker material similar to the overlying shales. It weathers to a cream olive or brownish gray, but has very little iron impurity and is a fine grained, firm sandstone.

$\mathrm{B}^{2}$ lies upon a six inch mass of fine, blue, fissile, argillaceous shale, which separates it from the second two foot course of sandstone, which is a solid, compact, and even textured calcareons sandstone of light green gray color, like that above, except that the worm tubes, Fucoides verticalis, are wanting. Below this, separated by thin layers of soft shale, are two thin courses, respectively twenty and ten inches thick, forming the bottom of the quarry. There are no worm borings in these lower courses, but the petroleum odor is more apparent than in the upper sands. 
The total thickness of this sandstone ledge is thus about seven feet, and it has furnished some very fine stone for railroad bridges and heavy masonry. In the shales forming the partings there are seen a few chips of fossil wood, but no other fossils were detected.

$\mathrm{B}^{4}$.-Under the sandstone is about ten feet of a greenish, nodular, calcareous shale, irregular and with rough fracture; mainly argillaceous; the upper half is more nodular, the lower strata becoming more even and smoothly stratified. This is nearly barren of fossils, but in it were seen traces of a small Cardium, with prominent beak, and a small ? Goniatites. Below this is a fifteen inch course of sandstone like the quarry stone above, underlined by green gray, nodular shales, which run down into bluish gray, rough surfaced shales, and at about three feet from the base of the sandstone there is a few inches of fissile, finely laminated, black shale $\left(\mathrm{B}^{5}\right)$, with petroleum odor and Sporangites. Under this, as far as was examined, were alternations of argillaceous, bluish green shales, with the thin, arenaceous shales so common in the Upper Portage deposits. The former shales are distinctly calcareous, and a single small Palconeilo was found about fifteen feet below the base of the quarry. This Palceoneilo is of the type of P. brevis and P. Bedfordensis, but of much smaller size. It agrees in shape and marking more closely with the Hamilton form $P$. plana, though but one-third the size. I have provisionally called it a variety of the latter species, with the varietal name Varysburgia; it is seen again in $472 \mathrm{C}^{1}$.

Stony Brook, Varysburg - $472 \mathrm{C}$.

The first rocky exposure is approximately 1,185 feet above tide. Beginning from the base and running up it presents the following characters :

$\mathrm{C}^{00}$ is a tough, calcareous sandstone, seen just at the water's edge. It is greenish gray in color, but is not a pure sandstone, showing some admixture of the greenish shale. It is immediately followed by $\mathbf{C}^{0}, 6$ inches to a foot of compact, black, bituminous shale, containing an occasional Sporangites and fragment of carbonized wood. Minute pyrite accretions are also seen, and an occasional worm boring perforating its lower layers from the green sandstone, $\mathrm{C}^{00}$, below. The line of superposition is irregular, as if the surface of the sandstone material were broken up and disturbed during the deposition of the first part of the black shale. The green, sandy shale occurs in irregular lumps and layers, and the black shale itself, after it began to be deposited in thin, perfectly smooth layers, is seen, on a cross section, to be interlaminated with very thin sheets of the lighter shale.

$\mathrm{C}^{1}$.-Above the black shale is, first, a foot of smooth surfaced, gray shale without fossils, followed by two inches of fine, soft, argillaceous shale, greenish gray in color, not very fissile, but breaking up in blocky flakes, with rough, uneven surface, and containing numerous fossils, and slightly calcareous - a frequent character of the fossil bearing shales 
of the Portage group. It appears like a soft mud deposit, stirred up by worms or mollusca moving about on the bottom, though the material is identical with the fine, smooth, fissile, olive shales met with in the same series. Where this shale cleaves with a smooth, even surface it is extremely rare to find the least trace of a fossil.

The fauna of this shale $\left(\mathrm{C}^{1}\right)$ is as follows:

Cardiola speciosa (= Glyptocardia speciosa Hall, 1885).

Coleolus acicula.

Goniatites bicostatus?

Lunulicardium fragile.

Pleurotomaria, a fragment,? P. capillaria.

Palconeilo plana, variety Varysburgia H. 'S. W. (n. var.).

Orthoceras, a fragment of a small, slender form.

Leda diversa.

The first two species of this list are common; the Goniatite is represented by several fragments; the other forms are rare.

These fossiliferous shales are followed by a few feet of blue gray shales like those below, capped by two layers of hard, sandy shales occupying a foot and a half, the lower part wavy and perforated by the Verticalis worm borings, the upper part concretionary and greenish in color. Above this for some fifty feet, are alternations of the greenish, soft, argillaceous shales, and thin, darker bluish, more arenaceous layers, with an occasional thin, black streak, quite black near the bottom, but only recognized by a darkening of the ordinary bluish shale toward the top. An occasional Cardiola speciosa, but no other fossil, was detected in the mass.

This is terminated by a solid, compact, gray sandstone, $\mathrm{C}^{2}$, two feet thick, darker than those above, but like them in having the upper part penetrated by the worm borings called Fucoides verticalis. The fillings are darker than the matrix and are apparently composed of the material of the overlying shale. This is $\mathrm{C}^{2}$; it is calcareous and in general character is like the majority of the gray sandstones of all this region. They may well be denominated Verticalis sandstones and are generally light gray in color, rarely less than two feet in thickness, calcareous, and very generally give out a strong petroleum odor when freshly quarried, which they lose upon exposure to the atmosphere. The Verticalis borings are sometimes wanting, but the top layer of the mass will generally be found to contain these markings. The Portage sandstones of Portageville and the falls are a well known example of them when deposited in thick masses.

In the sandstone, $472 \mathrm{C}^{2}$, a single fossil of considerable importance was found. It consists of a fragment of a fish plate, an inch wide by an inch and a half long, thin on one edge, but tapering at one corner to a third of an inch in thickness. The surface markings consist of tubercles partly confluent and resemble the markings of the Holoptychius giganteus scale figured in Murchison's Silurian System. It 
may be a fragment of the dorsal shield of some such fish as the Aspidichthys of the Huron shale, but the tubercles are not isolated, are closer together and more confluent than in Dr. Newberry's species of Aspidichthys clavatus. From the thickness of the fragment $I$ infer that it belongs to a dermal plate, and refer it provisionally to Aspidichthys clavatus Newberry.

Above $\mathbf{C}^{2}$ the sandy shales, in their alternation, predominate over the olive shales; they are more frequent, and stand out on the cliffs as stiff seams two to eight inches in thickness.

Nineteen feet above the top of $\mathrm{C}^{2}$ is the base of a second Verticalis sandstone, $\mathbf{C}^{3}$, eight feet thick, but not in a compact mass, being broken up by thin, shaly partings, though one solid layer two feet thick lies at the top. This is calcareous, as usual, and is impure by admixture of a little material of the green shales; also traces of iron are seen in the slight brownish tint of weathered surfaces. The ordinary nodular, olive shale underlies it, and this rests on the blue shales, which are becoming more common among the tougher, arenaceous deposits of these upper beds. In the bed of the creek a broken block of $\mathrm{C}^{3}$, or something very similar, contains a large Cladochonus, with eups nearly two centimeters long, and on the same slab are the impressions of a Cardiola speciosa and a Chonetes lepida. This fragment shows no trace of lime, but this is not strange, as some of the sands by weathering seem to lose what little calcareous matter they may have contained. The light olive shale associated with $\mathrm{C}^{3}$ is slightly calcareous, not fissile, but with blocky fracture and rough surface, approaching the character of the nodular shales. In it I found a specimen of what I first supposed to be Cardiomorpha suborbicularis, originally referred to Ungulina. Several specimens of this shell have been taken from various exposures of these olive shales of the Portage, presenting some features not referred to in the descriptions of the species. These are figured in Plate III, Figs. 13 and 14, and described below under the genus Lucina of Bruguière and referred to new species, $L$.Wyomingensis and $L$. Varysburgia. (See p. 44.)

The sandstone, $\mathrm{C}^{3}$, is immediately followed by tough, wavy, arenaceous layers, running up, in a few feet, into blue shales, then green shales, and the peculiar nodular, olive shales of rarer occurrence at this position.

These characters continue in irregular order for about twenty feet more, when a third Verticalis sandstone appears, $\mathrm{C}^{4}$. This is very similar to $\mathbf{C}^{3}$ in general characters and thickness. The upper part, particularly, shows the Verticalis markings. The nodular shales underlie this sandstone as they do the sandstones of lower position.

In the green nodular shales the following fauna appear:

Goniatites Patersoni.

Nucula corbuliformis, var., a small variety, in form and markings like corbuliformis, but about half the normal size.

Orthoceras pacator.

Lucina Varysburgia, n. sp. (?= Ungulina suborbicutaris Hall).

Cladochonus, sp. Same as seen in the Eastern Portage. 
Lucina Wyomingensis, n. sp. Plate III, Fig. 13.

Outline nearly circular, about $12^{\mathrm{mm}}$ wide; hinge margin nearly straight, $10^{\mathrm{mm}}$ long ; umbone subcentral, small, extending slightly beyond the hinge margin. Shell evenly arched, the umbonal ridge subangular anteriorly near the beak, but rounded beyond. Surface with strong concentric ridges, no radiate strix, except on the cardinal angles, where are several sharply defined, radiating striæ, stronger toward the margin and reaching under the beak; eight or nine of these ridges can be seen each side the beak, occupying the space of $4^{\mathrm{mm}}$ from the cardinal angle, beyond which no traces of striæ can be seen. The concentric folds are about the size of the larger folds of Iucina (Paracyclas) lirata, which the shell resembles. From that species it differs in the more erect beak, in the radiating striæ at the cardinal angles, and in the absence of finer intermediate concentric striæ; the concentric folds are rounded, and not sharp as in $L$. lirata.

From the Portage shales at Varysburg (472 A).

Lucina Varysburgia, n. sp. Plate III, Fig. 14.

Outline of shell nearly circular, $17^{\mathrm{mm}}$ long, $18^{\mathrm{mm}}$ wide. It resembles in form the Paracyclas Chemungensis of Hall, Geol. Surv. N. Y., Pal., Vol. V, Pt. I, Lamell. II, Plate XUV, Fig. 23, but still more the figure of Ungulina $=$ Cardiomorpha suborbicularis, $1883=$ Edmondia ? tenuistriata, 1885, Geol. Surv. N. Y., Pal., Vol. V, Pt. I, Lamell. II, Plate LXIII, Fig. 9. The surface is nearly smooth, slightly and evenly convex, except in the presence of a slight sulcus, separating a triangular portion of the anterior? cardinal angle. The cardinal angles near the margin are marked by radiate striæ fainter and fewer than in $L$. Wyomingensis, but of the same character; four or five are visible on each side. There are faint concentric striæ visible near the margin of the shell; also very faint radiate lines,

In a second specimen, which is crushed, but appears to belong to the same species, there are stronger concentric folds near the front margin. The beaks are erect and nearly central, low, and scarcely extending beyond the hinge margin. Upon first examination. I was inclined to refer this form to the species originally described as Ungulina suborbicularis by Hall in Geol. of N. Y., 4th dist., p. 243, Fig. 2, 1843. This was figured in plates and explanations of Lamellibranchiates, Geol. Surv. N. Y., Pal., Vol. V, Pt. I, Lamell. II, Plate LXIII, Figs. 9, 10 (issued in 1883), under the name Cardiomorpha suborbicularis; but in the final volume (Vol. V, Pt. I, Lamell. II), published in 1885, the species is altogether discarded and the Figures 9 and 10 are referred to another genus, Edmondia?, and described as a new species, E. tenuistriata, on page 393. (See also Am. Jour. Sci., 3d ser., Vol. XXXII, p. 192.) The original is said to come from the shales of the Chemung group near Elmira, instead 
of Eighteen Mile Creek, Portage group, from which the original of Ungulina suborbicularis is recorded. So far as literature goes, we are left no means of distinguishing Ungulina suborbicularis, except the original brief description in the Geology of New York, first dist., 1843. The condition of the specimens is too imperfect to enable us to recognize such surface markings as are given on Fig. 10, Plate LXIII, Geol. Surv. N. Y., Pal., Vol. V, Pt. I, Lamell. II. The specimens before us also differ from the Ungulina and from any described Lucinas of the Devonian in the radiating striæ on the cardinal angles.

This mass, $472 \mathrm{C}^{4}$, tends to be flaggy and break up into layers an inch or a few inches thick, and it is less easily separated at the top from the coarse shales that follow. A few feet above the solid part of this sandstone mass the shales are bluish and break up into irregular slabs, rough surfaced, and a few of the layers contain abundant specimens of the Spirophyton cauda-galli.

$\mathrm{C}^{5}$.- The shales containing the Spirophyton are rather darker than the general color in this part of the section, of bluish green tint, and calcareous. Worm tracks are abundant, producing markings very similar to what are usually called Fucoides graphica, if not identical with them. These conditions continue upwards, varying somewhat, but with the general character of coarse, blue gray shales and thin, arenaceous layers occasionally containing numerous specimens of Spirophyton, till we reach the highest sandstone of the section, $\mathrm{O}^{6}$.

$\mathrm{C}^{6}$. - This is a thick ledge of solid saudstone about 8 feet in thickness at the thickest part exposed. It appears to be a lenticular mass, thinning out in two directions; the grain is a little coarser, mica specks are more numerous, and the weathering gives it a decidedly yellowish tint, from the presence of iron. It is not calcareous, so far as observed, nor were any traces of the Verticalis worm-borings seen, though they may appear in the top layers covered by soil.

This terminates the rock exposure of this ravine ; the top of $\mathrm{C}^{6}$ is approximately 1,345 feet above tide level, or 160 feet above the base, $472 \mathrm{C}^{00}$. This section shows us the general law of the appearance of the Verticalis sandstones in relation to the black shales. The sandstones first begin to appear soon after the last black' shale; after a genuine Verticalis sandstone of two feet or more in thickness has appeared, no black shale is seen again. The sandstones appear in this section about twenty-five feet apart, becoming thicker above and farther separated from one other.

They certainly begin in the midst of the green shales of the Portage, with its characteristic fanna, and, as will be shown further on, continue after this fauna ceases; their order of appearance in thin shales is similar in each case: the nodular, green, calcareous shales precede the sands and the bluish and more arenaceous deposits follow. The greenish shales are evidently the mark of the older conditions and the bluish shale of the later, as the former are more frequent and characteristic below, 
while the bluish shales and thin, flaggy, and often wave marked sands are characteristic in the higher part of the series.

In relation to other sections, the base of $472 \mathrm{C}$ probably laps over the top of $468 \mathrm{D}$, the latter not reaching quite to $\mathrm{C}^{2}$, but passes to the top of the recurrent black shales.

\section{DESCRIPTION OF WORM TRACKS.}

Arenicolites duplex, n. sp. Plate IV, Fig. 9.

In the green shales in the lower part of the Stony Creek section was found the single specimen which is figured in Plate IV, Figures $9 a$ and $9 b$. This was lying horizontally in the rock and combines several interesting features. At the free end (upper in the figures) the specimen presents in each of the arms the characters so frequently met with in the New York Devonian, and when regular often spoken of as Fucoides graphica. When closely examined these are found to be not stems leaving their impression in the mud, but the fillings of grooves made in the surface of the mud and filled by repeated depositions of thin layers of mud in the groove. In the lower part of the figure will be seen the mode of joining of the two tube fillings, curving around in a regular arch, the arch being repeated a number of times at different places, but nowhere as strong as the side tubes. This character is repeated in the forms called Spirophyton (see particularly Spirophyton velum of the 16th Ann. Rep. Reg. Univ. N. Y., Plates LXXX, LXXXI, originally figured by Vanuxem in the Geol. N. Y., 3d dist., p. 177). I liken them to the vertical borings called by Salter Arenicolites and by various authors Scolithus and Fucoides, and consisting of tubular fillings more or less vertical in the rock.

I select the generic name Arenicolites, following Salter, who proposed to restrict this name (an adaptation of Binney's name Arenicola) to those worm borings connected by a loop or appearing in pairs and showing double openings (see Salter, Quart. Jour. Geol. Soc.; London, Vol. XII, p. 248, 1856; Vol. XIII, p. 204, 1857).

The explanation of the formation of such dissimilar markings by the same organism is easily understood by watching the common earth worm penetrating deep into the soil, out of sight, and after a rain storm coming to the surface, stretching out its length, and by sudden retraction drawing sticks and leaves and loose fragments into the mouth of its tube.

I can imagine how a worm with slightly modified habit might bore its tube in the mud and with its posterior part anchored in the hole throw its body out, curving it to one side, and thus form a loop, which, by sudden retraction, would leave the kind of mark seen in the Spirophyton. And it is easy to conceive how the same kind of worm which left its mark on the surface might perforate vertically in the raud, as we find worms doing today. 
I call this specimen Arenicolites duplex, but imagine the maker of the track was nearly related to the maker of the markings called spirophyton, and that the vertical borings so common in the sandstones of the Upper Devonian were made by the same kind of animal, though many species or even genera may have been engaged in forming these various worm tracks.

Daubree quarry, Bennington, Wyoming County, N. Y.-478 A.

This quarry is situated on the hillside above the railroad, westward, between Sierk's and Earl stations on the Tonawanda Valley and Cuba Railroad, $3 \frac{1}{2}$ miles south of Attica. According to estimates based upon the grade of the railroad, the top of the quarry is approximately 1,465 feet above tide. The rock onterop was first struck about 40 feet below the top of the quarry and measured up; a few ontcrops below this point furnished specimens, but their altitude was not measured-only their order.

$\mathrm{A}^{1}$, altitude 1,426 feet, a calcareous sandstone averaging a foot in thickness, gray olive, with Verticalis, followed above by seven and onehalf feet bluish and nodular shale.

$\mathrm{A}^{2}$, altitude $1,433 \frac{1}{2}$ feet, two feet of massive, gray, calcareous sandstone, weathering brownish, with Verticalis, followed by six feet of bluish and nodular, olive shales, then an 11 inch sandstone seam, then five feet and a half of shales and a six inch seam of sand, then nine feet shales, in which Spirophyton and the so-called Fucoides graphica appear, bring. ing us to the base of the main quarry stone. The shales immediately under it, bearing Spirophyton, are greenish gray, calcareous, and rather soft, breaking with rough surface.

The quarry stone, $\mathrm{A}^{3}$, is light gray, calcareous, and very uniform and massive; in the quarry it is composed of a ten inch course at the bottom, then what appears to be a solid course of seventy-one inches (but in quarrying there are a few lines of cleavage), on top of all a fourteen inch course, in the upper part of which Verticalis tubes are abundant. Above the quarry about twenty feet are exposed of blue gray shales, and towards the top a few thin sandstone layers. The fifty feet below $\mathrm{A}^{1}$ is composed of bluish and gray shales, with hard, flaggy, arenaceous layers, and below, at about 1,375 feet to 1,380 feet, is a layer of nearly pure limestone, outcropping in a ledge of several inches thickness, but mostly covered, a few feet above which is a stratum of black, fissile shale with Sporangites.

The next exposure examined below this is at Sierk's station, where black shales appear both above and below the railroad, and they continue upward, appearing in considerable thickness, certainly fifty feet above the railroad. There is a thickness of 275 feet above the lowest black shales at Sierk's before they entirely cease. Taking the upper beds of the black shales as criteria, there would be evidence of very liftle, if any, dip from Attica (468 D) to Sierk's (473 B), and even at Varysburg 
(472) they reach above 1,200 feet in their recurrences. At Java, eight miles farther south and three miles west of Varysburg, the black shales appear in thick masses considerably above 1,200 feet altitude, and underlying the fine, thick sandstone, above 1,300 feet altitude, is a layer of black shale with Sporangites and a strong smell of petroleum. This quarry sand of $473 \mathrm{~A}^{3}$, if we regard it as equivalent to $\mathrm{C}^{6}$ of 472 , which is also underlaid by a shale bearing spirophyton, dips to the south at about fifty feet to the mile.

If now we compare this with the Java section (475) we find that the first strong sandstone stratum $\left(475 \mathrm{~A}^{6}\right)$ actually underlaid by a black shale lies over seventy feet higher than the first sandstone of Varysburg $\left(472 \mathrm{C}^{2}\right)$. And across the county, eastward, the highest streaks of black shale do not reach much above 1,050 feet altitude, at Portage Falls, but the sands beginning at the upper falls occur in masses scores of feet thick before an altitude of 1,300 feet is reached.

These facts tend to show that in this region the rocks show as great differences on passing from west to east in line of the supposed strike as they do from north to south in line of the dip. The relation stratigraphically between the black shales and the Verticalis sandstones is not uniform, eren within the limits of a single county. There is nothing to show that there is any considerable folding of the general rock masses to account for these differences.

The only feasible explanation seems to be that the Verticalis sandstone is stratigraphically connected with the cessation of the black shales, and that the black shales run up higher in the midst of the Portage green shales, as we trace them upward, in a western and southwestern direction.

This points to a possible explanation of the apparently much higher position of black shales in Ohio, in relation both to the lower deposits and to the subcoal conglomerates, upon which point further light must be thrown by the study of the sections farther west as we approach and enter Ohio.

Sierk's Station (T., V. \& C. R. R.), Wyoming County, N. Y.-479 B.

The railroad grade at this station is approximately 1,100 feet above tide level. The profile of the road, which I was permitted to consult through the kindness of Mr. J. V. D. Loomis, general freight and passenger agent at Attica, gives the original survey of the road, but I was not able from the maps at hand to locate precisely the present station at Sierk's. Taking the altitude of the grade at Attica as 998 feet and at Earl's as 1,178 feet, I estimated that Sierk's crossing is not far either way from 1;100 feet. About fifteen feet below the railroad, the lowest exposure is a massive, black shale. The black shale is the principal rock, though for twenty-five or thirty feet upward blue shales alternate with it. 
The black shales, $473 \mathrm{~B}^{1}$, resemble very closely the second recurrence of black shale at Attica, as seen in $468 \mathrm{C}^{3}$ or $468 \mathrm{E}$. It is fissile, with some arenaceous particles, weathers with brown iron stain, has petroleum odor in the freshly opened strata, and contains Sporangites and Styliola. This station is three miles a little west of south from station $468 \mathrm{C}$ and $\mathrm{E}$, and the black shales at the bottom are nearly on a level with the lower black shales of $468 \mathrm{C}^{3}$ and $\mathrm{E}$. The section $468 \mathrm{D}$ contains no such massive black shale and begins about a hundred feet higher. It is evident, therefore, in these three miles going southward, either that the black shales increase in thickness upward or that there is very slight dip of the rocks, not over fifty feet in the three miles. This is further corroboration of the view expressed in the discussion of $473 \mathrm{~A}$. (See p. 47.)

\section{Ravine tast of Java Village, Wyoming County, N. Y.-475 A.}

This station is nine miles north of Arcade (474), about eight miles southwest of Varysburg (472), and two or three miles west of the direct line from.Attica (468) to Arcade (474). In direct line it is about twenty miles, west and a little north of Portageville, lying about six miles north of the latitude of the falls. The altitude is estimated from a series of levelings run from the railroad at Java Center, $475 \mathrm{~A}^{6}$, showing the top of this sandstone to be approximately 1,315 feet above tide level.

This sandstone $\left(\mathrm{A}^{6}\right)$ is a ledge of about two feet workable sandstone, as seen in the old Macoon quarry. It is a solid gray sandstone, the thickest course averaging a foot in thickness and calcareous. Two brachiopods were detected in it, one a minute shell, like a Cyrtina, but too indistinct to be clearly defined, the other a large Spirifera, over an inch wide, the best specimen crushed, but showing the ventral sinus with plications about the same size as those on the main part of the shell. This is plainly of the $S$. disjuncta type, but it would be difficult to determine it certainly. What is preserved of it looks like a Spirifera disjuncta with extended hinge and moderate area. With these were found fragments of crinoid stems. This is the lowest point at which traces of the Chemung fauna have been seen along this meridian, and it is of particular interest on account of the prominent stratum of black shales underlying it by only a few inches bearing a few sporangites and, when freshly broken, giving out a strong petroleum odor. The sandstone has the same odor when freshly broken. It is followed above by soft, argillaceous shales, much as in the MeGee quarry at Arcade $(474 \mathrm{~A})$, and lies upon a few inches of similar shales $\left(475 \mathrm{~A} 5^{\mathrm{a}}\right)$. The black shale $\left(\mathrm{A}^{5}\right)$ is massive, six to eight inches thick, a decided black, but not the brown black of the lower representatives. Below the black shale, for some fifty feet, the rock is the ordinary alternation of bluish shales and thin sandstones, the latter often wavy and flaggy, as seen in the Upper Portage series. At this point is a heavy sandstone ledge which could,

$$
\text { Bull. } 41-4
$$


not be reached, forming a fall of some twenty or thirty feet. Under this ledge the cliff is composed of soft green shales, with frequent bands of black, increasing in thickness toward the bottom, with an occasional seam of the green, nodular shales such as those seen at Varysburg and other places. At abont thirty-five feet below the brink of the fall the green shales were examined and furnished numerous small fossils $\left(A^{3}\right)$.

$\mathbf{A}^{3}$.-This is an olive gray shale, soft, argillaceous, calcareous, and nodular in places. The fossils determined are-

Cardiola speciosa, numerous.

Coleolus acicula, rare.

Paloeoneilo (small).

Goniatites (minute).

Below this are a few feet of shale, then another strong black streak, another mass of olive shale, and a thick mass, six feet or more in thickness, of brown black shale $\left(\mathrm{A}^{2}\right)$, with Sporangites and strong petrolenm odor; under this is seen, in the bed of the stream in the village, a gray sandstone, $A^{1}$, very similar to the bed at the base of $472 \mathrm{C}$, calcareous, with petroleum smell and traces of crinoid stems, but no other fossils were detected. This base is not far from $\mathbf{1 0 0}$ feet below $\AA^{6}$ and at an altitude a little over 1,200 feet above tide.

It will be seen from this description that the black shales continue to recur frequently up to, say, 1,250 feet altitude, and are represented by a stratum of six inches average at 1,300 feet. If we compare this section with that at Portage Falls, we appear to be perfectly justified in regarding it as equivalent to the rocks underlying the upper falls, that is, entirely below the genuine Portage sandstones. This conclusion appears to be supported by the general nature of the strata as well as by their stratigraphic order. Though lying at a considerably higher altitude than the Portage Falls sandstones, the facts of the apparent running out of the black shaies and of the absence of any thick, massive sandstone up to the top forbid co-ordinating it with lower strata of the Portage section, where the black shales are frequent, or with strata above the Portage sandstones, where the black shales cease to appear. But the occurrence of the Spirifera, of decidedly Chemung type, shows plainly that when the sandstone $475 \mathrm{~A}^{6}$ was deposited the Chemung fauna could not have been geographically far distant and was in full force somewhere. 


\section{CHAPTER III.}

THE PORTAGE SANDSTONES AND THE FAUNAS OF THE CHEMUNG GROUP.

As we approach the southern boundary of Wyoming County the Portage sandstones form the principal rock outcrops and slight traces of the Chemung fauna begin to appear. Crossing into Allegany County, the Chemung rocks are the only rocks on the hills, though in the northeast corner of the county the lower rocks are still Portage, and in the southern part of the county the higher hills are capped by conglom. erates - the flat pebble conglomerate in several places, but the Olean? conglomerate at Little Genesee.

The group of rocks included in this chapter are represented at the following stations:

Wyoming Oounty: Arcade, 474; Allegany County: Rushford, 476; Cuba, 477; Black Creek, 478; Rockville, 479; Belfast, 480; Caneadea, 481. Here is also included the section at Portage Falls, 482.

Portageville, Livingston County, N. Y.-482.

The Portage sandstones, as seen in section 482, were early recognized as an important member of the Upper Devonian series in Western New York.

Prof. James Hall, in the first reports of the State survey, described them as exposed at Portage Falls and regarded them as characterizing the close of the Portage formation and separating it from the Chemung group above.

"The upper part of the Portage group," he says (Geol. of N. Y., 4th dist., 1843, p. 484), "consists of a mass of slightly argillaceous sandstone, compact and fine grained, from 150 to 200 feet thick, in some places containing pyrites which stain the rock an iron rust color. This rock is quarried in blocks from 1 to 3 feet thick, and of any required thickness and any required size; it breaks easily when first quarried and will scarcely stand the vicissitudes of climate."

These Upper Portage sandstones are regarded in the early reports as characteristic of the termination of the true Portage series in this part of the State. The presence of the "vertical fucoids" in this heavy sandstone is another character marking the terminal mass. (See op. cit., p. 248.) But it did not escape the acute observation of the New York State geologist that these distinctions between groups of continuous sedimentary deposits must be, from the nature of things, provisional and in great measure local.

The re-examination which I have made of these deposits brings to light another fact, viz, that the conditions associated with and marked by the deposition of these gray sandstones - which were generally 
slightly calcareous, and when fresh distinctly bituminous to the smell and showing almost universally the presence of the "vertical fucoids" at their upper junction with the shales - were the conditions regularly following the termination of the black shales. Although in some cases there may have been thin deposits of the sandstones between black shales, it is not until after the cessation of the Devonian black shales that these massive gray sandstones appear in full force. When they appear in the midst of the Portage shales containing the Portage fanna they are, so far as observed, barren. The lower down in these Portage shales we find them, the darker, the more finely grained, and the more impure are they by admixture of argillaceous matter; and after reaching the Chemung faunas the sandstones are of lighter color in the western areas of the State and of purer sand and coarser grain in proportion to the lateness of the beds in the general Chemung series.

The altitude of these sandstone deposits at Portage Falls is between 1,100 and 1,200 feet above the sea. The New York, Lake Erie and Western Railroad bridge passes over the gorge at an elevation of 1,314 feet above tide level. The top of the quarry sandstone is about 100 feet below the bridge, or say 1,200 feet altitude. Good quarry stones are found at the level of the old canal road, which is at an altitude of 1,125 feet to 1,130 feet along these cliffs, and, even considerably lower, thick courses of the sandstone are seen, but there the shales prevail.

The prevailing color is a pure light gray of slightly olive tint, abou the same shade as the Rockville stone, somewhat lighter than the upper stone of Wyoming County, north, and dar ker than the upper Rushford stone. The Cuba stone has a decidedly lighter shade and a more open and coarser texture. No fossils have been seen in these typical Portage sandstones. The black shales are recognized nearly up to the upper fall, which may be regarded as the first genuine stratum of the sandstone, but no black shales have been detected by me in this section above the strong stratum of 3 or 4 feet thickness of this sandstone. Interstratified with the black shales below are seen the regular gray and olive shales of the Portage group, containing the Portage fauna, Cardiola speciosa, Goniatites complanatus, Palcooneilo plana, var.

The lighter colored bands have the peculiar nodular structure frequently found in the Portage formation. The highest band of black shale I saw in the ravine contained a few well defined specimens of Sporangites. The petroleum odor associated with all these gray sandstones following the black shales of the Portage group gives strong reason for the opinion that they are the sandstones which occur farther south, and there, covered by thick masses of overlying strata, contain the oils reached by drilling.

MeGee Quarry, Arcade, Wyoming County, N. Y. $-474 \mathrm{~A}$.

This quarry is on the hillside south of Arcade, about three-fourths of a mile from the center of the town and east of the cemetery. The 
top of the main quariy stone ledge, $\mathrm{A}^{2}$, is approximately 1,600 feet above tide. This altitude is based upon railroad grade at Arcade and measurement from that by aneroid barometer. Both Locke level and barometer have been used in obtaining levels in this survey, and while I regard them as approximately correct for purposes of geological comparisons of levels of the respective rock exposures; they may often vary several feet from the absolute altitude above sea level. ${ }^{1}$

The region north of Arcade for several miles is high rolling land, with heavy soil, and directly north no rock exposures are met with till passing beyond the summit in Java township.

The quarry $474 \mathrm{~A}$ is composed of the following courses from below upward:

$\mathrm{A}^{0}$.- Three foot sandstone, fine working and soft when first quarried, running below the base of the quarry as now worked. This is followed by

$\mathrm{A}^{1}$. - Six inches of soft, blue, argillaceous shale, weathering quickly into a tough clay;

$\mathrm{A}^{2}$ is a 16 inch sandstone, compact; and

$A^{3}$ is six or seven inches of thin parting of soft blue shale; then six inches irregular sand; then slate with sandstone veins and masses, or what may be called a clay breccia, appearing as if it were a clay bottom which had assumed some solidity when it was violently disturbed by the rapid insertion of the sand, often with mica, so that the clay nodules, like broken lumps, are in the lower layer of the sand and all mingled with it. This peculiar condition of rocks has been obserred in several localities, associated with the incoming of the conditions in which the Chemung fauna appears. A similar rock appears farther east, at the base of the Catskill rocks.

$A^{4}$.-Then follows a 13 inch sandstone, compact and calcareous; at the top of this sandstone, separating it from the course lying above, is another layer of the peculiar claystone conglomerate; then a 20 inch course of sandstone; then a 6 inch course.

$A^{5}$. - The whole is terminated by an uneven mass of the clay pebbles, embedded here in a calcareous mass of purple color, with some sand,

${ }^{1}$ Though $I$ have employed an aneroid considerably in the past few years- nsing a Troughton \& Simms registered, compensated for temperature - so far as the machinery is concerned, I am convinced, after trying several instruments, that the more delicate the instrument the more certain it is to be affected by the atmospheric fluctuations and to record only approximately altitudes which require more than ten minutes in passing between them, even under like conditions of temperature; and in the field, without a stationary barometer for comparison, altitudes determined by a single reading cannot be considered as more than approximately correct when pressure of atmosphere is the basis of the determination.

All the altitudes given in this report, unless particularly stated as railroad grade, must be regarded as subject to such correction. The error in any case, however, I do not believe is enough to seriously affect the geological considerations for which the measurements are made, as in each case the diurnal fluctuations and the changes in temperature have been taken into account, as well as the general atmospheric conditions, in making up the estimated altitude. 
but principally calcareous matter composed of fragments of shells and bryozoa and crinoid stems, very much pulverized, but showing their source in the occasional fragments, large enough to examine, and terminating above in soft, argillaceous shales.

In this quarry the sandstones are of a gray color, weathering brownish or chocolate, then bleaching upon long exposure to a purer gray, and some fresh specimens gave a strong petroleum odor. No Verticalis borings were detected. Even weathered samples are calcareous, but fresh, light gray samples are highly calcareous, and the purple layers, such as terminate $\mathrm{A}^{4}$, are more calcite than sand.

The layers of soft, green, argillaceous shale, whether in layers or in pebble-like nodules embedded in the sandstone or limestone, are not calcareous. There appear, also, at these intervals, between compact sandstone and thick strata of green shale, thin, vein-like streaks, very uneven but in the main horizontal, stratified with the shales, of nearly pure quartz sandstone, varying from a sixteenth of an inch to an inch or so in thickness. They are often pure white or very light gray, with not a trace of calcite. There are also frequent partings of grains of mica, forming very evenly laminated, flaggy layers, from a quarter of an inch to several inches thick.

In the arenaceous limestone layers there are traces of several fossils which are decidedly distinct from the Portage fauna. The limestone has a purplish tint and is distinctly crystalline in some parts. It appears to weather quickly by solution of the calcite, leaving a greenish brown, loose, crumbling sandstone. Among the pulverized fossils several generic characters were identified (but they are too fragmentary for the determination of specific relations): little bryozoan stems like Deriopora, numerous small sections of crinoid stems, pieces of a brachiopod with the structure of Orthis, a small Spirifera with plications in the ventral fold, another portion of the beak of a Spirifera, which may be the same species, the surface characters not visible. From the fragments obtained the Spirifera appears to be of the S. Archiaci type of S. disjuncta, near S. Whitneyi Hall or S. Orestes Hall \& Whitfield, from the Rockford beds of Iowa. Although it is not possible to strictly identify the species, it is important to note that it is a representative of the group of spirifers so common in the Chemung group. In some parts of this strange deposit are found numerous bivalve crustacea, Estheria and Leperditia, and Entomis?, the latter of a green color or filled with green phosphatic? mud. In section 475 the sandstone, $475 \mathrm{~A}^{6}$, has a Spirifera similar to those just mentioned.

Although in both cases we see only slight traces of the fauna, I feel confident that what we do have is not the disintegrated material of an earlier age, but signifies the presence, at no great distance geographically, of the fauna which we know immediately followed the close of the Portage while these deposits were being made. The nature of the deposit and its associations are very similar to the calcareous stratnm at High Point, Naples, Ontario County, in which a peculiar fauna for New York rocks was discovered, an account of which is given in Am. Jour. 
of Sc., $3 \mathrm{~d}$ ser., p. Vol. XXV, pp. 97-104, 1883. There is nothing in the fragments found in stations $474 \mathrm{~A}$ and $475 \mathrm{~A}$ to prevent them from belonging to the same fauna and the probability is strong that they are from a common source. Further search should be made for this interesting forerunner of the Chemung fauna of New York.

Although the precise equivalency may not be determinable between this particular limestone deposit and any other series of deposits in which this fauna does not appear, it is a very suggestive fact that here for the third and fourth times traces of the Iowa Devonian fauna oceur in New York deposits just at the point of transition from the Portage fauna, which seems to be peculiar to the east, to the Chemung fauna, which occupied the interval between it and the lowest eoal formations.

\section{Rushford, Allegany County, N. Y.-476.}

The altitude of Rushford at the railroad station I estimated by aneroid readings running from Attica and to Cuba to be nearly 1,500 feet. These were long runs, but as they were severe tests upon the accuracy of this kind of estimate of altitude it was gratifying to learn later, through Mr. W. E. Wormelsdorf, the engineer of the railroad, that the measured altitude of Rushford station was 1,504 feet above tide. By aneroid estimates the deposits $476 \mathrm{G}^{0}$ are 1,350 feet or less, $481 \mathrm{~A}$ is about 1,600 feet in altitude, $481 \mathrm{~B}$ near 1,700 , and $476 \mathrm{~A}$ is not far from 1,770 feet above tide.

The dip along Caneadea Creek is slight; near $A$ it is perceptibly northward, but nearly level elsewhere, and it is probable that here is the southern rise of the gentle undulations in the rocks which produce but slight variation in the general southerly dip of the rocks in this part of the State. The dip is rarely more than fifty feet per mile and except in very limited areas rarely less than fifteen feet per mile southwestward.

The section $476 \mathrm{~A}$ is a ledge exposed alon gside the railroad near the bridge, No. 57, between two and one-half and three miles north of Rushford.

$A^{1}$. - At the top are exposed six feet or so of soft, argillaceous shales which weather to an olive green; no fossils discovered; mica partings are seen, and by continuous deposition of the mica occasionally sheets an eighth of an inch thick separate the soft shales.

$A^{2}$. - Under the shales are about six feet of sandstone and mixed sand and clay. The sandstone at top is rather coarse, of loose texture, with occasional mica grains, with some iron stain and occasionally ironstone nodules, not calcareous, weathering brown, dark brown, to almost chocolate black. The sandstone rests on a kind of mixture of sandstone and clay nodules, with large roundish masses of micaceous limestone or concretions of dark greenish gray, with much mica and fragments of wood fossilized. These calcareous masses have the petroleum odor common to many other similar masses. Where they are in contact with the shales fossils appear.

$A^{3}$ is a second shale underlying the mass $A^{2}$; it is a bluish, fine, mud shale, not so evenly bedded as $\mathrm{A}^{1}$, but breaking with conchoidal fracture 
when not weathered; this is veined with horizontal streaks of almost pure silicious sand, very light gray, with rough surface, often showing worm tracks. In the midst of the shale is an uneven mass of sandstone similar to that above, varying from eight to ten inches in thickness, and below are shales similar to those at the top. In a part of the exposure the color of the sandstone of $A^{1}$ at the juncture with the clay nodules (whether from weathering or not is not apparent) is a decidedly brownish red, the red of the Catskill rocks farther east, and the sandstone is slightly calcareous. It contains a unique fauna, though mingled with some Chemung types.

Fauna of the Centronella Red Band.- $476 \mathrm{~A}$.

Of the fossils the most abundant form is a small terebratuloid shell, in size and general form most closely resembling Centronella Julic Winchell, of the Marshall sandstones. Next to this in abundance is a large, winged form of Spirifera disjuncta.

There are also -

Rhynchonella? camerifera Winchell.

Productella Shumardiana, var.

Pleurotomaria, sp.

Rhynchonella contracta, var. (See Pl. 54 A, Figs. 50, 51, and pp. 417, 418,

Geol. Surv. of N. Y., Pal., Vol. IV, Pt. I. The specimens of this station resemble the finer plicated forms of Rockford, Iowa, which were referred to $R$. contracta, var., and in a note were said to resemble young of $R$. eximia Hall.)

Nucula, n. sp., marked like a $N$. lamellata, but in outline approaching a Grammysia Hannibalensis (such as Meek gave in Pl. XVI, Fig. 5c, Geol. Surv. of Ohio, Vol. II, Pal.).

Nucula, n. sp., gibbous, quadrate, beak nearly central.

Cytherodon (Schizodus) pauper?

Crania, sp.

Amboccelia umbonata, var. recta.

Naticopsis? sp., an allied form, new.

An incrusting Bryozoan - fragments.

Crinoid stem fragment.

$476 \mathrm{~B}$ is a little outcrop of six feet, about thirty feet below $476 \mathrm{~A}$. It is mainly thin layers of a very tough sandstone interstratified with softer shales. The sandstone is light colored, not calcareous; in one stratum the sandstone is very calcareous and appears to be a concretionary layer, not in balls, but nearly continuous.

$B^{1}$. - The sandstone contains several fossils; the first two species in the list are abundant.

Leiorhynchus mesocostalis, varying to L. sinuatus. Ambocoelia umbonata.

Rhynchonella contracta, var.

Productella speciosa to P. hirsuta.

Spirifera mesocostalis, second and first varieties with median septum. 
Streptorhynchus? (small).

Orthis impressa? large (faint).

$\mathrm{B}^{2}$. - In a softer piece of shale from this horizon a Spirifera disjuncta was seen.

$\mathrm{B}^{3}$.- The calcareous streak contains A mbocolia and traces of the Streptorhynchus.

The form and variation of the species of the sandstone $B^{1}$ are very similar to the species met with several hundred feet lower in a similar stratum in the shales at $476 \mathrm{G}$.

The outcrop $476 \mathrm{C}$ is near bridge No. 59 and may be fifty feet lower than A. The principal stratum, $\mathbf{C}^{1}$, is a strong, massive sandstone of six feet thickness at the bottom of the exposure, with soft argillaceous shales above for fifteen or twenty feet, interrupted by an irregular stratum $\left(\mathbf{C}^{2}\right)$ of sandstone, averaging about a foot in thickness, in the midst of arenaceous shales, and in places becoming coarse sand of loose texture, weathering yellow upon exposure. At one part of the exposure the sandstone is very coarse, more like a fine conglomerate, with pebbles as large as an eighth of an inch in diameter and of flattened form, resembling in general character of the mass the lowest conglomerate or flat pebble conglomerate, as seen at $484 \mathrm{D}$ and other places. This contains fossils, as will be seen beyond. $\mathrm{C}^{3}$, a shaly mass underlying this seam, contains also fossils of a decidedly Chemung type. This is strongly calcareous in places.

A calcareous slab from the bed of the creek appears to be from the same stratum, and its fauna will be given under $476 \mathrm{~B}^{\mathrm{x}}$, as it contains in fine state of preservation several species not found in the exposure in place.

On going down to the village thicker masses of conglomerate were found in the fences. This conglomerate, in the character of the gravel composing it and the fossils contained, appears to be identical with 476 $\mathrm{C}^{2}$ in its coarser parts, and it is reasonable to infer that the conglomerate in the fences, with Chemung fossils and appearing there in slabs of several inches thickness, is from the same horizon as $476 \mathrm{C}^{2}$ or was deposited at a recurrence of the same conditions higher up ; $476 \mathrm{~A}$ approaches very closely to the same conditions. In the latter, coarse, loose sand is seen, with a few pebbles, but no mass of gravelly sand or fine conglomerate.

$476 \mathrm{C}^{1}$ is a fine, massive sandstone, in thick courses, without shales, of 6 feet thickness. The bottom courses are stained brown upon weathering and show mica grains conspicuously through the mass. A single fossil was found in this part of the sandstone, a dorsal valve of a large Productella, which may be defined as a large quadrate $P$. lachrymosa, moderately gibbous for a dorsal valve and showing clear indications of the radiating wrinkles which are more prominent in carboniferous species. The upper part of the sandstone is in a course of some 2 feet thickness as it appears in the ledge, massive, a pure gray, of uniform texture. with strong petroleum odor upon fracture, which the specimens 
have not lost after six months in a dry room. There is only a faint trace of calcareous matter in these sands and the upper courses show only a slight yellowish tint of gray upon weathering.

Above the sandstone $\mathrm{C}^{1}$ are soft shales $\left(\mathrm{C}^{2}\right)$, tending toward a green color at first and strongly iron stained on weathering; on passing upward a few feet the shales become sandy $\left(\mathrm{C}^{3}\right)$ and in places calcareous. The fauna appears to be the same for both and the lithological characters seem to vary locally in the relative prominence of the shales, sandy shales, or calcareous layers.

$\mathrm{C}^{3}$ contains the following fauna:

Spirifera mesocostalis (common), var. 2 and 3, with high area and strong median septum.

Athyris Angelica, several specimens, but not common.

Spirifera disjuncta, var. like $S$. Whit neyi.

Rhynchonella contracta, var. (small) common.

Productella hirsuta?, rare.

Streptorhynchus Chemungensis, several.

Centronella Julia, rare.

Mytilarca Chemungensis, one specimen.

A fine slab filled with fossils was found in the bed of the creek between $\mathrm{C}$ and $\mathrm{B}$, and marked $\mathrm{B}^{\mathrm{x}}$. The fauna of $476 \mathrm{~B}^{\mathrm{x}}$, as well as the character of the rock, leads me to regard it as belonging to the same horizon as $476 \mathrm{C}^{3}$. It is more fossiliferous and is a calcareous mass which has in all probability fallen down from the cliff at some point the continuation of $476 \mathrm{C}^{3}$.

The species identified are:

Streptorhynchus Chemungensis, large, gibbous, of the quadrate form, with mucronate ears.

Spirifera disjuncta, the variety with high area and quadrate form.

Spirifera? Whitneyi, a single specimen presenting some of the characteristics of this Iowa form, but comparison of many forms leads me to think this but an extreme form of the $S$. disjuncta type.

Rhynchonella contracta, a small variety, resembling var. saxatilis Hall, Geol. N. Y., Pal., Vol. IV, Pt. I, p. 417, Pl. 54 A; also another variety very similar to Fig. $23, \mathrm{Pl} .55$, but not belonging to the species $R$. duplicata, to which that figure is referred.

Productella costatula, with concentric wrinkles.

Athyris Angelica.

Orthis Michelini.

Chonetes scitula.

Centronella Julia.

Chotetes, sp.

Productella onusta.

$476 \mathrm{C}^{2}$ is an outcrop of sandstone south of the exposure of $\mathrm{C}^{1}$ and somewhat higher. I was not able to trace its exact equivalent in the 
cliff above $\mathrm{C}^{1}$ and conclude that the character of the seam rapidly changes. At $\mathrm{C}^{2}$ it is not over a foot thick, not massive, but is a coarse, sandy layer, tending to pebbly conglomerate in places, weathering yellow, and is in the midst of the same soft, rough shales which lie above $\mathrm{C}^{2}$.

The fossils are Streptorlyynchus Chemungensis (large), Rhynchonella contracta, Spirifera mesocostalis, and some crinoid fragments. Markings, like those called Fucoides graphica, are conspicuous on the surface next the shales. The sandstone is hard and very compact in some parts; in other places it suddenly becomes coarse and loosely agglutinated, and contains pebbles an eighth of an inch in size, forming a fine gravel conglomerate.

$476 \mathrm{C}$ is a coarse sandstone forming a stratum above $\mathrm{C}^{3}$ and is probably the continuation of $\mathrm{C}^{2}$. It is a loose grained, coarse sandstone, weathering yellow, not massive, but apparently a local bed. It contains -

Spirifera mesocostalis, second and third vars., with strong median septum and moderately high area.

Productella lachrymosa.

Rhynchonella contracta, varying to the form called $R$. suborbicularis.

Orthis impressa, large, broad form (frag.).

Orthis (Michelini or Vanuxemi), small.

Centronella Julia.

Rhynchonella contracta (small var.).

Bellerophon moera? (internal casts).

Orthoceras Demus?

$\mathrm{C}^{4}$.- Other slabs of sandstone were found loose in the creek below with a similar fauna. In one hard silicious layer the following association of species was met:

Leiorhynchus of the L. sinuatus and L. multicosta types.

Productella, resembling $P$. hirsuta, but with strongly wrinkled margins. Amboccelia umbonata.

Spirifera mesocostalis, second var. with median septum.

These sandstones $\left(\mathbf{C}^{2}, \mathbf{C}\right.$, and $\left.\mathbf{C}^{4}\right)$ are not calcareous, but are more purely silicious than the ordinary sandy layers of this neighborhood. The loose conglomerate masses met with in the fences between $476 \mathrm{~A}$ and Rushford are composed of fine, silicious pebbles, often dark in color, but after weathering coated with a dark brown covering of iron stain. The pebbles are of the flat form met with in the lower conglomerates farther south, and the masses appear to be at best only a few inches thick, grading at their upper or lower surfaces into coarse sandstone.

The following species were found in these fragments :

Spirifera disjuncta.

Spirifera mesocostalis, with median septum, the small and the coarse type both represented. 
Euomphalus, sp.? This is represented by only a fragment, but it has the character of this genus so far as it goes.

In these more northern exhibitions of the flat pebble and fine, polished gravel conglomerate the fossils associated leave no doubt as to their general position in the series. The presence of spirifera mesocostalis with Spirifera disjuncta shows us that this conglomerate was not restricted to the closing stage of the life history of the Chemung faunas. In middle and southern Allegany County S. mesocostatis had been ab. sent from the faunas a long time before the laying down of the typical deposits of the flat pebble conglomerate occurred, as at Wolf Creek and Portville. The period of the deposit of the Olean (the Portville) conglomerate was doubtless of long continuance, a period of violent oscillation, of rapid erosion, and of rapid spreading out of the coarse sediments. It put an end to the marine conditions for all this eastern area and closed the Devonian age. Butmy study of the section herein discussed reveals the general law that the faunas of the Upper Devonian in this area maintained their integrity longer the farther distant they were from the center of origin of the sediments, which must have been somewhere in the region of the Appalachian axis, and also that the coarser shore deposits, worn pebbles and gravel, were occasionally carried out and spread over the bottom during a comparatively early stage of the Upper Devonian faunas.

Interpreting this for Western and Central Pennsylvania I should expect there to find greater thickness and more numerous deposits of coarse sand and worn pebbles below the Olean conglomerate, extending far down into the Chemung period, as marked by the life; but I should expect the fossils to be rare after the appearance of the red and micaceous green shales, and the few that did appear should represent earlier stages of the faunas than those appearing in like lithological conditions in Western New York.

Caneadea Creek, below East Rushford,-476 G.

This section continues from $481 \mathrm{C}$ upward. The shales at the base $\mathrm{G}^{0}$ are more bluish than lower down, but are fissile and weather much in the same way. They contain more fossils and a few more species, but they are evidently of the same fauna. The streaks of hard, nearly white, silicious material are more frequent, and calcite appears in thin, greenish white, argillaceous layers. Mica appears occasionally, peppering the surfaces of some of the thin shales.

$476 \mathrm{G}^{0}$ contains the following species :

Leiorhynchus mesocostalis, abundant in layers.

Leiorhynchus multicosta (or L. sinuata), var.

Orthis impressa, large, wide form, frequent.

Spirifera mesocostalis, second var., mucronated, rare. Ambocoelia umbonata Hall, var. 
Rhynchonella Stephani, var, approaching $R$. Saffordi var.

Athyris Angelica.

Worm tracks.

Productella lachrymosa, var. stigmata.

The Leiorhynchus is more common where the shales and sandy layers meet.

In the higher layers of the shale, where the sandy character becomes predominant $\left(\mathrm{G}^{1}\right)$, there is a Rhynchonella difficult to distinguish from the more regular forms of the Leiorhynchus occurring below. One of them is distinctly the Rhynchonella contracta of Hall (Pl. 55 A, Fig. 30, Pal. N. Y., Vol. IV, Part I). Others are irregular in the plications, more like Leiorhynchus multicosta Hall, and are possibly what Professor Hall has called $L$. sinuata.

For the first thirty feet above, the thin shales $\left(G^{2}\right)$ and sandstones prevail, the sands in the upper part appearing as thick as six inches. At thirty-five feet a strong seam of sandstone $\left(G^{3}\right)$ of three or four feet thickness appears, with some thin shale partings, so that the mass cleaves upon weathering into layers six to ten inches thick. In some of the exposures the sandstone is broken into thin, flag-like slates by thin layers of pinkish mica. Higher the fissile shales appear, but the fossils are not: seen, and the arenaceous layers are more frequent and thicker than be. low. About ninety feet above $\mathbf{G}^{3}$ appears a second massive sandstone $\left(476 \mathrm{G}^{4}\right)$. This forms the top of the cliff. Although I could reach its base I could not get at the top of it, which was covered by loose talus from the shales still higher. It appears to be from six to eight feet thick. For eighteen inches or two feet at the base it is solid, massive, of a gray color, weathering to a slight brown or chocolate tint, and of loose texture; above the rock is more firm and gritty, but no specimens were found to be calcareous. This is probably the rock referred to in the Report on Geology of the Fourth District of New York, p. 485, as extensively used for grindstones and quarried. It is the only exposure seen between Caneadea and Rushford likely to furnish material fit for such a purpose.

Just under $\mathrm{G}^{4}$ Rhynchonella contracta, Spirifera mesocostalis, a small Palceoneilo, and stems of plants (or worm tracks?) were found in arenaceous strata; in more shaly strata the Leiorhynchus, varying as below from L. multicosta to L. mesocostalis, was seen. The clay nodules, so often found associated with these sandstones, were seen at the base of $\mathrm{G}^{4}$, some of them being elay ironstone. The spirifera mesocostalis of these sands is the variety with extended ears, moderate area, median septum developed in the ventral valve, and reduplicated fold in the sinus.

$476 \mathrm{G}$ (loose). In the bed of the creek near $\mathrm{G}$ were found slabs of conglomerate, resembling very closely those met with in the stone fences above Rushford and of which distinct traces were found in place at $476 \mathrm{C}^{2}$. Although we cannot identify the horizon of these loose slabs with precision, the evidence is strong that they were deposited before the Chemung fauna ceased. The sources of the Caneadea Creek are high up in 
the hills to the north and west in the towns of Lyndon, Farmersville, and Centreville, and nothing has been discovered to show that any of these hills run above the rocks bearing Chemung fauna.

The pebbles are flattened and range from coarse sand to fine gravel. Ironstone concretions are contained in the mass; when not weathered, the matrix is decidedly calcareous, and, while the pebbles themselves are often dark colored, green, and smoky quartz, the iron stain, upon weathering, coats them brown, giving the weathered slabs a chocolate brown color. Several fossils are found in the mass, though not in condition to identify always with certainty.

Spiriferc mesocostalis, the second type, with finer plication and extended wings, and well develoved median septum.

Streptorhynchus Chemungensis, of good size.

Orthis, sp., several fragments too imperfect for specific identification.

Rhynchonella? Sappho, var.

'Numerous worn fragments of fish bones, and a fish jaw, Dipterus Nelsoni

Newberry.

This resembles Newberry's Ctenodus serratus in general form, but the teeth are not serrate, although slightly wrinkled along the edge, which might possibly be the result of attrition of a serrate tooth.

While revising the manuscript in March, 1886, I submitted this specimen to Prof. J. S. Newberry, who identified it with Dipterus Nelsoni, a species which he has described from the fish beds at Warren, Pa. It is somewhat smaller than the original of that species. The matrix in which it is embedded is also very similar to that of the Warren fish bed.

\section{DESCRIPTION OF FISH REMAINS.}

Dipterus Nelsoni Newberry, ms. Plate III, Fig. 1.

This is a small jaw, referred to this species after comparison with Professor Newberry's original specimens from Warren County, Pennsylvania. The grinding surface is of hard enamel, triangular in shape, grooved by seven grooves radiating from near one angle, which is smooth and rounded and divided into finger-like ridges. The tops of the ridges and bottoms of the grooves are subangular. The ridges are arranged in pairs, every other groove running back a little farther than its neighbor toward the angle from which they radiate, and each ridge is slightly notched by four or five constrictions on the side; these notches are only superficial, and upon the crest of the ridges produce only faint undulation, no definite serration. The dimensions of the specimen (No. 16055 U. S. Nat. Mus.) are: length, $20^{\mathrm{mm}}$; width, $11^{\mathrm{mm}}$; length of the process of the jaw vertical to the grinding surface, $11^{\mathrm{mm}}$.

The original is from a gravel-like conglomerate found at Rushford, Allegany County, N. Y. (loose), but traced to the midst of Upper Chemung rocks and associated with Chemung fossils. 
Dipterus (?) levvis Newberry, ms. Plate III, Fig. 2.

This is a small and worn specimen, evidently distinct from $\mathrm{D}$. Nelsoni and possibly a worn representative of Dr. Newberry's species $D$. laevis. It is nearly as large, but proportionately shorter; the grinding surface has but four finger-like ridges, which are smoothly rounded and hard; the bottoms of the grooves are also rounded. It is smaller and has fewer ridges than the typical specimens of $D$. laevis, and, while this may partly be the result of attrition, it is with some doubt that I refer it to the species, and in case future discoveries prove it to be distinct I would propose $D$. Alleganensis for this form. It occurs in a fine pebble conglomerate at Little Genesee, Allegany County, N. Y., in the Upper Devonian.

\section{Cuba, Allegany County, N. Y, -477.}

Cuba, the third township north from the State line and in the western tier of townships in the county, is situated about fifteen miles north of Pennsylvania and thirteen miles south from Rushford, 476. The Erie Railroad grade is given as 1,542 feet above sea; the altitude of the grade of the canal railroad (Rochester division, Buffalo, New York and Philadelphia Railroad) is called 1,488 feet. Several exposures were examined on the hillsides, all at about the same level.

477 A.-The Armstrong quarry is extensively worked just above the Erie Railroad near the depot. Some ten or twelve feet of good building stone can be quarried here; the base of the quarry is about thirty feet from the railroad, or nearly 1,570 feet in altitude. Several courses of solid, even grained sandstone lie above the base, with some intervening layers of shale or shaly sandstone. Below the sandstone are some twenty feet of soft, fissile shales, bluish at the bottom, tending to olive toward the top, and weathering iron stained.

$477 \mathrm{~B}$ is three-quarters of a mile north, on the same level, and is now abandoned - the old Guilford quarry.

$477 \mathrm{C}$ is Smith's quarry, on the east side of the valley and a mile and a half northeast of $\mathbf{A}$ on the same level. The quarry rock is a iight gray, calcareous sandstone, strongly bituminous upon fresh fracture. The grain is generally fine, and though working easily when fresh is more tenacious than the Berea sandstone of Euclid or Amherst, Ohio; but the grain is coarser than the Portage sands and of lighter color. Upon weathering there is enough iron to give the stone a creamy to yellowish brown tint. This ferruginous quality is associated with the thinner, more flaggy structure; the purer, thicker courses are of a lighter and purer gray color. The lowest course, from which thick slabs are blasted or wedged off, running from three to four feet thick, makes the finest quality of building stone. A second thick course in the center of the quarry furnishes three to four feet thickness of stone, in which occasionally are seen Verticalis perforations on the upper layers. Above this the courses are thinner, rarely furnishing over a foot of 
sandstone. Between the layers of shale in these sandstones are the brachiopods.

There appear to be two quite distinct faunas present in the quarry. Although the upper layers of sandstone are very similar in general character to the lower, more strongly calcareous deposits, generally the lower thick beds carry scarcely anything but a lamellibranch fauna, with occasionally an Orthoceras. The lamellibranch fauna is generally found in the midst of the solid sandstone, with Grammysia communis as its most abundant species. The brachiopod fauna occurs higher up in the thinner sandstone, where the argillaceous matter is so interstratified as to make poor building stone and the shells (in the principal layer) are so thick as to make the stone unfit for cutting. In the fauna the Spirifera disjuncta is the most abundant form and lamellibranchs are rare, though occasionally a single specimen of Sanguinolites appears at the base or top of the stratum.

Below the sandstones are exposed some twenty feet of soft, fissile shales, $\mathrm{A}^{1}$ and $\mathrm{A}^{2}$, containing another distinct fauna. Only a few specimens were found, but those were well marked Lingulas and a few other forms. The Lingula is the more conspicuous and frequent form, and it is indistinguishable from the Ohio Lingulas of the Cleveland shale at Euclid, Ohio. These lingula shales are, however, light in color at the base, the ordinary blue shale, and toward the top are light olive green upon weathering.

Lingula fauna of $477 \mathrm{~A}^{2}$ :

Lingula Melie.

Chonetes lepida, or small C. scitula.

Palcooneilo, sp., a small form.

Discina, sp.

Sanguinolites rigidus (= Sphenotus contractus Hall, 1885).

Grammysia fauna of $477 \mathrm{~A}^{3}$ :

Grammysia communis.

Grammysia communis, var. approaching G. cuneata.

Grammysia communis, var. very short.

Schizodus rhombeus, var.

Aviculopecten, a variety near A. cancellatus.

Edmondia? Philipi.

Pterinopecten suborbicularis.

Orthoceras pacator?

Crinoid stem fragments.

Brachiopod fauna of $477 \mathrm{~A}^{6}$ :

Spirifera disjuncta, abundant.

Rhynchonella contracta, small var., frequent.

Streptorhynchus Chemungensis, frequent.

Athyris Angelica, frequent.

Chonetes scitula. 
Productella costatula.

Productella, sp.

Ceriopora, sp.

(Crenipecten? impolitus.)

Sanguinolites rigidus (= Sphenotus contractus Hall, 1885).

The first four species constitute the main bulk of the fossils; the remaining species are represented by several specimens in the lot collected, but are not common. Spirifera disjuncta is rery abundant in quarry A, and with few Streptorhynchus Chemungensis, while the latter species is almost as abundant as the spirifer in some layers of $477 \mathrm{~B}$.

Guilford Quarry, Cuba, N. Y.-477 B.

Sandstone, massive gray, weathering brown; some layers highly ferru. ginous, the fossiliferous layers decomposing by solution of calcareous matter and producing brown rottenstone. Some pebbles are seen; but no regular conglomerate layers. In the lower sandstone is the lamellibranch fauna, as in $477 \mathrm{~A}$. Above is a thinner lajer, more calcareous, filled with brachiopods.

Brachiopod fauna of $477 \mathrm{~B}$ :

Spirifera disjuncta, abundant.

Streptorhynchus Chemungensis, common.

Chonetes scitula.

Rhynchonella contracta, var. small.

Productella onusta.

The Streptorhynchus is gibbous, often extremely so, and the Spirifera disjuncta has the median fold duplicated.

Smith Quarry, Cuba, N. Y.-477 C.

The lithological and stratigraphical characters are essentially the same as in the Armstrong quarry, $477 \mathrm{~A}$.

The brachiopod fauna is the same, though Productella and Strepto. rhynchus are more frequent than in the more southern exposure at $A$.

The fossils obtained are :

Spirifera disjuncta.

Streptorhynchus Chemungensis.

Productella onusta.

Rhynchonella contracta, var.

Rhynchonella duplicata?

Athyris Angelica.

Pleurotomaria, sp., a finely striated form.

Sanguinolites rigidus (= Sphenotus contractus Hall, 1885).

Productella, near $P$. arctirostrata.

Ceriopora, sp.

Buill, $41-5$ 
The brachiopod fauna of these three Cuba quarries is in all essential points identical with the fauna of $476 \mathrm{~B}^{\mathrm{x}}$.

Ravine in South Cuba- $477 \mathrm{E}$.

Near the base of this ravine there are some thin sandstone layers, but, comparing it with the Cuba quarries a mile or two north, I judge that the first exposures at the base of the ravine are stratigraphically equivalent to the upper part of the Armstrong quarry and that the fine quarrystone layer is below the surface. The shales predominate throughout, though in the lower part some solid sandstone strata, a foot or more thick, are seen. The ravine begins (the first rock exposure) at about 1,600 feet altitude and rocks are visible to nearly 1,725 feet.

Near 1,625 feet altitude or a little higher is an abundant brachiopod fauna, in a calcareous sandstone seam $\left(\mathbf{E}^{2}\right)$, with the same species in general as in $477 \mathrm{O}$, the Spirifera disjuncta and Streptorhynchus Chemungensis both abundant, and the more common species. Above this stratum no strong seam of sandstone occurs; there is an alternation of thin arenaceous layers, with prevailing argillaceous shales.

Near the middle of the ravine is a layer of rather coarse micaceous sandstone $\left(\mathrm{E}^{4}\right), 18$ inches thick; soon above this traces of red coloring begin to appear in the generally olive argillaceous shales. These argillaceous shales become prominent at about 1,700 feet altitude and con. tinue to the top of the ravine. At several places they run into brown or red shale, and one layer of several inches is strong brownish red and contains fossils $\left(\mathrm{E}^{5}\right)$.

Brachiopod fauna of $477 \mathrm{E}^{2}$ :

Spirifera disjuncta.

Streptorhynchus Chemungensis.

Chonetes scitula.

Rhynchonella contracta.

Productella hirsuta.

Productella costatula, and varieties.

Ceriopora, sp.

Crinoid stem fragments.

Grammysia communis, var.

In thick greenish shale $\left(\mathrm{E}^{3}\right)$ :

Spirifera disjuncta.

Streptorhynchus Chemungensis.

Leptodesma, near L. sociale.

In brownish sandstone, near bottom, $477 \mathrm{E}^{4}$ :

Athyris Angelica, abundant.

Rhynchonella contracta, var.

Productella, sp.

Above $\mathbf{E}^{4}$ the rocks are generally argillaceous, and, while generally olive green in color, contain streaks of red and brown and some thin 
streaks or nodules of oölitic red iron ore. The fauna of these beds is probably uniform and the reddening of the shales does not prevent the presence of numerous fossils.

Fauna of $477 \mathrm{E}^{5}$ :

Orthis Leonensis, abundant.

Lyriopecten, $\mathrm{sp} .=$ ? L. orbiculatus.

Rhynchonella contracta, small.

Spirifera disjuncta.

Ceriopora sp., abundant.

Aviculopecten cancellatus?.

Leptodesma, sp.

Athyris Angelica?

Station $477 \mathrm{H}$ is a low bluff alongside the stream which runs into the Cuba valley from the southeast, and is situated about two miles nearly south of Cuba. Stratigraphically the rocks are apparently the soft argillaceous shales following the quarry sandstones of Cuba and are nearly equivalent to $477 \mathrm{E}^{1}$, at the base of section $\mathrm{E}$, which lies only half a mile north of $\mathrm{H}$. The shales are normally bluish in tint, being slightly ferruginous, weather to an olive color, tending to a brownish shade; they break up into fissile flakes after weathering, but the bedding is not so fine as to give the true fissile character to the rock in mass.

The fossils are numerous in some layers, in others rare. In the beds examined, the Chonetes is most abundant; the Athyris, Streptorhynchus, Productella, and Spirifera frequent, the other species rarer. With the exception of Spirifera and Streptorhynchus the species are generally small.

The following species were identified in the fauna of $477 \mathrm{H}$ :

Chonetes scitula.

Streptorhynchus Chemungensis.

Productella costatula.

Athyris Angelica.

Spirifera disjuncta.

Orthis Leonensis, small size.

Ceriopora, sp.

Crania, sp.

Palceoneilo brevis, var.

Palcooneilo, sp., near P. filosa.

Palceoneilo, sp., a minute form, possibly young.

Rhynchonella contracta, small var.

Pleurotomaria filitexta.

Leptodesma, a minute specimen.

Leptodesma sociale?

Goniophora Chemungensis, small.

Mytilarca Chemungensis.

Centronella Julia? 
Crinoid stem fragments.

Aviculopecten cancellatus.

Modiomorpha?

Following up the valley from $477 \mathrm{H}$ southeastward, two exposures were met with near the southern boundary of Cuba township. They are about $2 \frac{1}{2}$ miles south of $477 \mathrm{~A}$ and respectively 2 and $2 \frac{1}{2}$ miles east of the same point. Stratigraphically they lie above the section $477 \mathrm{E}$, station $477 \mathrm{G}$ being not far above the top of $\mathrm{E}$, and $477 \mathrm{~F}$ is some 60 feet higher.

Fauna of $477 \mathrm{G}$, in the sandy layers, weathering brownish to dark bluish brown :

Spirifera disjuncta.

Athyris Angelica.

Plant remains.

Rhynchonella, sp.

Bellerophon, sp.

Chatetes, sp.

In the soft, coarse, argillaceous shale, weathering brownish olive, were: Rhynchonelia, sp.

Palceoneilo, imperfect specimen.

Leptodesma Mortoni?

Fauna of $477 \mathrm{~F}$, in greenish, arenaceous shale:

Spirifera disjuncta.

Streptorhynchus Chemungensis.

Chonetes scitula.

Sanguinolites rigidus (=Sphenotus contractus Hall).

S. clavulus and a variety resembling Nyassa arguta in general form.

Palconeilo Bedfordensis.

Mytilarca Chemungensis.

Leptodesma Mortoni.

Plant stems.

Leptodesma potens.

A comparison of the several faunas from Cuba and the iminediate neighborhood gives the following as the general character of the two hundred feet or so which we are able to examine.

(1) Olive green to bilue, argillaceous shales with a Lingula fauna, when most pure and fine, as seen in $477 \mathrm{~A}^{1}$ and $477 \mathrm{~A}^{2}$.

(2) This is followed by sandstone, locally, of solid, massive character, calcareous and often strongly impregnated with petroleum. Where this sandstone is purest and most massive, the fauna is mainly lamellibranchs. In the more argillaceous lajer, where the alternating arenaceous and argillaceous deposits are more frequent and mingled, one of the typical Upper Chemung brachiopod faunas appears, with abundance 
of Spirifera disjuncta, and in some exposures and layers Streptorhynchus Chemungensis is common ( $477 \mathrm{~A}, \mathrm{~B}$, and C).

(3) Above the sandstones appear shales again, of the olive, argillaceous character, varying from pure, fine, soft shale to arenaceous shale with more or less iron stain. In this zone Athyris Angelica nay be found, lamellibranchs of several genera, and sereral of the common species of the sandstones below.

(4) Next appear traces of those iron gray, micaceous sandstones, so common in the lower Catskill rocks further east, and streaks of red iron ore and red shales. The red shales still contain Chemung brachiopods, Spirifera disjuncta, and other species. The most characteristic brachiopod is a small Orthis (O. Leonensis); this occurs quite abundantly in a thin, arenaceous, reddish brown shale. Here, too, in the midst of the soft, olive shales is seen red oölitic ore, but only in thin veins or nodules. $I_{t}$ is interesting to notice that in the lowest clay iron nodules of Chemung and Tioga Counties, New York, in the midst of the same Upper Chemung brachiopod fauna, are seen the representative of the Orthis of that section as well as the more typical form of 0 . Michelini, showing conclusively that this typo of Orthis is associated with nearness to shore conditions of habitat.

(5) Above this the Chemung brachiopods come"in again; also a new lamellibranchiate fauna. This time Leptodesma, Sanguinolites, and Avic. ula are more common, and this rock is a fine, arenaceous shale, from bluish to olive gray' in color. This is $477 \mathrm{~F}$ and $\mathrm{G}$. Traces of pebbles are seen in the lower sandstones; some of them are an inch in diameter, but no collection of pebbles forming conglomerate was seen. In this section are seen, for the first time going up, distinct masses of red iron ore.

The brachiopod fauna (477 $\mathrm{A}$ and $477 \mathrm{C}$ ) is remarkable for the absence of any trace of Spirifera mesocostalis or Orthis impressa; and Strophodonta Cayuta, Productella lachrymosa, Orthis Tioga, and Cryptonella Eudora are entirely absent, unless we may regard Orthis Leonensis as a small variety of $O$. Tioga and some of the gibbous forms of Productella as extreme varieties of the common form of the eastern section. Yet all these species are common in the typical Chemung fauna of the Chemung and Tioga County sections. Several of these species do not appear at all in this Wyoming-Allegany County section, while such species as Athyris Angelica, the gibbous varieties of Productella, and the smaller varieties of Rhynchonella contracta and Khynchonella duplicata appear to be wanting in the eastern section, though often abunlant in the Allegany County section. This difference in fauna cannot be geological, for it characterizes the whole Chemung group fauna. We can only look, therefore, to geographical conditions to explain the faunas.

Some of the species of the eastern Chemung do appear at the base of the Chemung fauna in Allegany County, such as Spirifera mesocostalis, Orthis impressa, and the common Chemung Leiorhynchus ; but it 
becomes evident upon comparison of the two sections that upon passing upward the characteristic Chemung species mentioned above become more and more strictly confined to the east. Again, the species which appear associated with Chemung species in the Allegany County section and that are wanting farther east are of the same types and, in some cases, the same species which are characteristic of Lower Carboniferous rocks of the States farther west. - The conclusion appears plain that with the passage of Upper Devonian time over Western New York territory there was a shifting of the faunas in an easterly direction, and that with such shifting species which are regarded as belonging to a later period, when they occur more isolated in the western interior, appear in the western part of New York before the close of the Chemung fauna, but farther east, in Tioga County, do not appear at all up to the close of the Devonian. This study of the faunas gives us a hint toward solving the relation of the eastern and western beds.

If the Waverly or Lower Carboniferous fauna may be regarded as a separate and complete fauna, it was doubtless a local one, and it may be regarded as probably contemporaneous with a part of the Upper Devonian of New York. The indisputable evidence we have that during this Upper Devonian epoch the faunas were moving eastward over Western New York gives reason for the belief that species which belong to a later horizon must have come in from the west, and that the normal contemporaneous faunas farther west were of a later type than in the east. Examination of the species confirms such views. The Productellas of $477 \mathrm{O}$ are frequently of the very gibbous form, agreeing in this respect with specimens from the section $476 \mathrm{~B}^{4}$ of Rushford. Although the specimens are generally smaller, the larger specimens are very like the larger Waverly forms (Geol. Surv. Ohio, Vol. II, Pal., Pl. 10) mentioned by Meek, and the Streptorhynchus Chemungensis from these beds reaches a very gibbous form not readily distinguishable from Meek's Hemipronites crenistria of Ohio. The Palconeilo of these Cuba beds is different from $P$. brevis in the features distinguishing Meek's $P$. Bedfordensis from that species; it is, therefore, a variety approaching the Ohio Waverly type. The crinoid is of the Waverly variety of Forbesiocrinus communis type, as here recognized by stems, but in the fauna of $479 \mathrm{~A}^{4}$ represented by some specimens of the calyx.

We observe just under these rich fossil bearing calcareous sandstones, $477 \mathrm{~A}$, a series of fissile shales bearing a fauna of Lingula and other small delicate shells. Although the fauna is not strictly identical with that of the lingula shales of Van Ettenville, described in U. S. Geological Survey Bulletin No. 3, the stratigraphical sequence is the same and the general character of the fauna is similar. In that section the rich Chemung brachiopod fauna immediately follows the soft lingula bear. ing shales, and no similar shale was discovered below until within two or three hundred feet above the Genesee shale. In the western section the lingula bearing black shales are constantly recurring for a thousand 
feet above the typical Genesee shale, but this soft, olive mud shale, with Lingula, does not appear below this horizon (477 A).

In these lingula shales, in both the eastern and the western sections of New York, we find the first traces of the ironstone nodules, and the brown color from iron stain becomes more conspicuous above this hurizon, and this marks the lower part, if not quite the beginning, of the eommon marine fauna of the Chemung group. In the Ithaca section we observe a fauna resembling the Chemung fauna some eight hundred feet below the genuine Chemung fauna. It is preceded by a similar dark lingula shale, but the absence of Spirifera disjuncta and the rarity and small size of Productella alone suggest the fact that the Chemung horizon, as it is known in Western New York, has not been reached.

From these comparisons we conclude that the Van Ettenville shales and the following fossiliferous sandstones are the stratigraphical equivalents of the Cuba shales and its sandstones as seen in the Armstrong quarry. The interval below, down to the Genesee black shale, is mainly filled by rocks carrying Portage faunas in the Allegany County section, while the section of Tompkins and Tioga Counties holds a fauna only a few hundred feet above the Genesee shale, which is paleontologically intermediate between the Hamilton and genuine Chemung faunas.

Black Creek, New Hudson Township, Allegany County, N. Y.-- 478.

This station is northeasi of Cuba, about five miles from the Armstrong quarry (477 A), and estimating from the canal railroad (Rochester div., Buff., N. Y. and P. R. R.) grade by aneroid barometer, the quarry is approximately at the same altitude as the Cuba quarries, not far from 1,575 feet. The quarry has been extensively. worked, but is now abandoned. At the base is a heavy course of light colored sandstone, running from two to three feet thick; next above, five feet of thin layers of sandstone and shale; then two feet of solid sandstone, followed by a fossiliferous zone of a foot or so containing the brachiopod fauna, 478 $\mathrm{A}^{4}$; above this is another solid sandstone three feet thick, above which the thinner alternating shaly and arenaceous layers predominate. The lithological characters correspond very closely with those of the Cuba quarries, but the fauna differs slightly in its prevailing characters.

The tracing of actual equivalency of horizon is a matter of considerable difficulty on account of the absence of exposures at intermediate points. According to Prof. James Hall's original section, generalized for this part of the State (see Ann. Rep. of N. Y. Geol. Survey, 1838), a general dip of something like fifty feet to the mile is represented, and each of these quarries at Caneadea, at Rockville, \&c., is in a separate zone in the series, separated from others by considerable thickness of depos. its. My examinations lead me to the opinion that the general dip of these upper strata is by no means so great, and that there are also long folds in the strata, giving at some exposures even a decided dip 
to the north, thus complicating the task of following strata from exposure to exposure in traversing the country.

Knowing, as we do, that the faunas are considerably modified as we pass from east to west, even in a hundred miles, it should not surprise us to find a like difference between the more northern and more southern faunas of the same horizon. The differences in the faunas may be due to differences in geographical conditions on the same horizon or they may be modifications of the fauna, marking geological range or difference of horizon. The present fauna, to all appearances, is at the same altitude now as the Cuba brachiopod fauna, $477 \mathrm{~A}$. At the Cuba quarry the dip is slightly southward. At this station the strata are as nearly level as we can read; at Rockville, three miles farther north, there is a decided dipping to the north. From these facts the conclusion is strong that there is a gentle anticlinal fold near Cuba, sloping northward as we reach Rockville and already showing its southward slope at $477 \mathrm{~A}$.

The fauna of $478 \mathrm{~A}^{4}$ shows differences pointing to the characters of more eastern faunas or those that are met in the exposures farther north than 477. The presence of Orthis impressa, the broad winged, high beaked Spirifera disjuncta, and the presence of Spirifera mesocostalis may be noted in this connection. In making comparison of faunas, too, we find the same peculiarities in station $481 \mathrm{~A}$, which is actually less than fifty feet higher than $478 \mathrm{~A}$, and nine miles north and a little east, with the rocks again dipping northward, though at intermediate points the dip is decidedly southward.

If we consider each of the sandstone beds as relatively local, when a particular horizon is concerned it is more probable that the sandstone deposits for continuous geological epochs (at least for such length of time as the Upper Chemung may require) were nearly continuous, but shifted their geographical position, than that there was any total cessation and renewal of their deposition.

When we compare the faunas in similar or like lithological conditions, as a tentative rule (which further investigation may modify), we make the supposition that likeness in the composition of two faunas, i. e., the association of the same species, is more apt to persist through the gradual changes brought about by time and that constancy in the lesser varietal characters is more likely to signify likeness or equivalency in geological horizon; hence, if we have two faunas in apparently like conditions of matrix and in the same general geographical area, if the species are the same and those abundant and those rare maintain the same comparative relationship to the fauna, we infer that the fauna is, the same. If the species show the same varietal peculiarities, we say the horizon is synchronous; if the varietal characters differ, we say it is probably a.different horizon, although the species are identical. Hence in an imperfect fauna, the lack of the full complement of species might signify geographical shifting of the,fauna, but if the species that did 
appear presented the identical varietal characters, we would infer that the horizon was identical.

Fauna of $478 \mathrm{~A}^{4}$ :

Spirifera disjuncta, large, broad, mucronate form.

Athyris Angelica.

Rhynchonella contracta.

Crinoid stems.

Productella acutirostra, var.

Spirifera mesocostalis.

Orthis impressa.

Choetetes, sp.

The S. disjuncta is abundant; the other species are only occasional. The Productella, sp., is a large form, with the outline (dorsal valve) of a large $P$. arctirostrata, with stroug concentric wrinkles at the cardinal end of the shell, the front geniculate, the interior pitted like $P$. hirsuta. It does not agree with any of the ordinary New York forms, and in general resembles the carboniferous types, but is doubtless a variety of the gibbous Upper Devoilian type of Productella, and near the form called $P$. acutirostra in the reports. The same form is seen in $479 \mathrm{~A}^{4}$.

\section{Rockville, Allegany County, N. Y. -479.}

Situated in Belfast township, about nine miles northeast from Cuba (477); altitude, approximately, as determined from railroad grade and by aneroid barometer: $A^{1}, 1,410$ feet; $A^{7}, 1,460$ feet. The section near the old canal lock at Rockville is visible for about fifty feet. At the base is a thick sandstone seam $\left(A^{1}\right)$, six feet of it being visible. $A^{2}$ is shale of two feet thickness, then a second seam of sandstone two feet thick $\left(A^{3}\right)$. This is followed by shales and thin arenaceous layers for thirty-five feet, and at the top are two seams of sandstone less than a foot thick, separated by shales. The principal sandstones of the series are massive and of the deeper gray color of the true Portage sandstones, considerably darker than the Cuba stones and of finer grain, and have a strongly bituminons odor on fresh fracture. The shales are green to olive, soft, argillaceous, and do not differ materially from the soft shales which frequently appear in the Chemung series. The rocks dip evidently to the north, not extensively, but enough to show plainly that we are on the northern slope of a gentle anticlinal.

The brachiopod fauna is in the first and second sandstones; the most numerous fauna is just at the close of the second sandstones, in the soft shales, $479 \mathrm{~A}^{4}$. The upper sandstones are tough but thin, of a pinkish tinge, and contain minute streaks of brown iron ore. There is occasionally seen a passage of the sandstones into a local bed of gravels, with fine pebbles, flat and of a dark and even black color. These are cemented in a calcareous matrix.

Fauna of the calcareous sandstone, 479:

Spirifera mesocostalis (common). 
Sp. disjuncta (rare).

Orthis impressa.

Rhynchonella contracta.

Streptorhynchus Chemungensis.

Productella hirsuta.

Ambocoelia umbonata (rare).

Sanguinolites rigidus (= Sphenotus contractus Hall, 1885).

Crinoid stems (large).

Belleropicon moera? (frag.).

Nucula, sp.?

Platystoma, sp.?

Fauna of the olive shales, $479 \mathrm{~A}^{4}$ :

Spirifera mesocostalis (of smaller and finer structure than that of the sandstones).

Productella hirsuta.

Productella lachrymosa, var. stigmata.

Productella (with several varietal forms running off toward P. onusta and $P$. speciosa).

Chcetetes, sp. (a branching form, quite abundant).

Mytilarea Chemungensis.

Rhynchonella contracta (running into the form called $R$. sappho, var., by Prof. James Hall, Geol. Surv. N. Y., Pal., Vol. IV, Pt. I, Pl. LV, Figs. 49, 50).

The above species are found in abundance; the following are less common :

Spirifera disjuncta, a small variety, with very high beak, in general form and size closely agreeing with the Iowa S. Whitneyi Hall.

Orthis impressa.

Productella rarispina.

Athyris Angelica.

Orthis Tioga (or var. O. Leonensis), rare.

Crania, sp.?

Bellerophon, near B. Euclid.

Palceoneilo brevis.

Macrodon Chemungensis.

Modiomorpha subalata?

Modiomorpha quadrula.

Loxonema styliola.

Ptychopteria, a form near P. Eugenia (=P. Salamanca Hall, 1885).

Crenipecten obsoletus.

Crenipecten crenulatus.

Pterinopecten suborbicularis.

Aviculopecten, sp.?, a very finely striate fragment.

Forbesiocrinus communis.

Crinoid stems, another species, with nodose joints.

Chonetes scitula. 
Belfast Quarry, Belfast, Allegany County, N. Y. -480

This is an exposure about three miles east of the Rockville section, approximately 50 feet lower, or from 1,340 to 1,360 feet in altitude.

The sandstone $\left(480 \mathrm{~A}^{1}\right)$ is fine grained, of a darker shade and finer texture than the Cuba stone, and very similar to the Arcade stone (474 A). It also closely resembles the Rushford stone $\left(476 \mathrm{G}^{4}\right)$. The color is gray, with a slight brownish or chocolate tint, which changes upon weathering to a purer gray. It is calcareous and upon fresh fracture has the petroleum smell so common to these sandstones. Some layers are flaggy and separated by thin partings of mica. At the top of the quarry are very uneven layers, as if violent action of the sea had disturbed the bottom, making it uneven with pitholes. There are small masses of shale mingled with the sandstone and large irregular masses, calcareous agglomerations of pebbles or fine gravel $\left(480 \mathrm{~A}^{2}\right)$. These have something of the nature of concretions, but are mainly coarse sand and fine gravel cemented by calcareous mud.

In these were found the only fossils of the station. Above and below the sandstones the rocks are thinner layers of arenaceous and argillaceous shales, with no thick layers and no traces of fossils visible.

Fauna of the concretionary masses, Belfast, $480 \mathrm{~A}^{2}$ :

Orthis impressa, large, broad variety.

Productella hirsuta, with spines from cardinal margin. Spirifera mesocostalis, third var., with median septum. Rhynchonella contracta, approaching the $R$. eximia type. Amboccelia umbonata.

Athyris Angelica.

Crinoid stems, same as in 479 .

Leiorhynchus sp.

Productella onusta.

Chatetes, sp.

Streptorhynchus Chemungensis, var.

Caneadea, Allegany County, N. Y.-481.

The examinations at this station were confined to the exposures along Caneadea Creek, up to E. Rushford (481 C), and two exposures (481 A and $481 \mathrm{~B}$ ) made in the hill a few miles northwest of Caneadea by persons who supposed they had found a gold mine.

The altitude of Caneadea railroad station, based upon the profile of the old Genesee Valler canal - in the bed and along the towpath of which the Rochester division of the Buffalo, New York and Philadelphia Railroad is built-is 1,224 feet above tide. This benchmark I have not been able to identify precisely. By aneroid barometer, the cliff above $476 \mathrm{G}$ is estimated to be 1,490 feet in altitude. The cliff to the base, $\mathrm{G}^{0}$, is 140 to 150 feet, or say 1,350 feet in altitude. The other stations, according to 
aneroid reč̃oning, are, $481 \mathrm{~A}, 1,600$ feet, and, $481 \mathrm{~B}, 1,700$ feet in altitude.

The dip of the rocks in the creek is very slight, but what there is is northward. At $476 \mathrm{~A}$ two or three miles north of Rushford the dip is strongly northward, and at the base of the creek the rocks incline to the southwest.

Shean exeavation, above Caneadea, $-481 \mathrm{~A}$.

This section is an opening made on the farm of Mr. Shean, near the division line between Caneadea and Rushford Townships, about two miles in direct line northwest of Caneadea village. It was opened on the supposition that gold and silver ores were there in rich quantities. The report of this "silver mine" I heard of at several places in the county. By aneroid estimate the altitude is about 1,600 feet.

The rock exposed is mainly a gray calcareous sandstone, highly fossiliferous. The stone varies in the amount of calcareous matter. In the more compact portions the sandstone is of a dark bluish gray color and the matrix appears to be almost pure carbonate of lime; but where the sancistone is loose textured it is a pure light gray, with little or no carbonate of lime.

The facts suggest that the difference is due to a solution and removal of the lime from the more compact variety to form the loose textured, light gray variety. The presence of petroleum in the porous sandstones probably had no relation to the original deposition of the sandstones, but wherever these beds of calcareous sandstone were made porous by removal of the carbonate of lime the conditions were present for the absorption and retention of petroleum distilled from underlying black carbonaceous shales. The sandstone weathers a little brownish, but the iron stain is very slight. The sandstone becomes coarse in places, forming a fine gravelly conglomerate, with flat and dark colored, silicious pebbles, the matrix calcareous, and containing fragments of fish bones, shells, and chips of wood very similar to $476 \mathrm{C}^{2}$.

The fossils in $481 \mathrm{~A}$ are:

Ambocoelia umbonata, abundant.

Productella (lachrymosa, var.? see beyond).

Productella hirsuta, var., small.

Rhynchonella contracta.

Spirifera mesocostalis, second var. with strong median septum, and third var. coarse and with reduplicated fold.

Orthis Tioga.

Orthis impressa, larger.

Streptorhynchus Chemungensis.

Rhynchonella, sp.? (like R. Horsfordi, broad).

Crinoid stems.

Chotetes, sp., slender branching form. 
? Lingula, with punctate inner layer.

Spirifera disjuncta.

Aulopora, sp.

?? Cryptonella, sp., a fragment.

Caneadea Creek, lower part.-481 C.

This is the section referred to in Geology of Fourth Dist., N. Y., p. 485 , as "a good exhibition of the characteristics of the base of the Chemung group of this part of the State, better than is elsewhere seen." The distinction between this section and those of Steuben County consists mainly in the prevalence here of the "pure aluminous shale of a deep green or bluish green color," with interrals only of thin sandstones. The green shales referred to prevail in all the lower part of this ravine. I would describe them as a fissile, greenish gray shale, argillaceous, weathering brownish with iron stain, and containing at intervals streaks, from an eighth of an inch to several inches in thickness, of hard, silicious sandstone, the surface of which is often rough and uneven and sprinkled with mica grains. In the upper parts, from $476 \mathrm{G}$ upward, the sandy lasers are more conspicuous and thicker and of looser texture and coarser grain, forming strata of a foot or more in thickness. These are referred to in another place.

The shales contain a few fossils as low down as Caneadea, but there they are rare and are mainly Leiorhynchus mesocostalis and $L$. multicosta. A single Rhynchonella sappho, var., was found, and a Productella, which, though differing from any particular figure and description, is probably a variety of $P$. hirsuta. This general character of deposits continues up to the base of the cliffs at $476 \mathrm{G}$. an account of which is given in another place.

Friendship, Allegany County, N. Y. -491 .

The exposures at Friendship were examined at Mr. P. Miller's quarry and in the ravines south of the village. They lie at about the same altitude as the Cuba quarries and above them and are directly east of Cuba. Substantially the same series of rock deposits and the same faunas were met with as in the ravine south of Cuba $(477 \mathrm{E})$. In the higher exposures the micaceous flags were reached; a red band was seen before the close of the Chemung fauna.

Mr. Miller showed me several fine specimens of Dictyophyton, two of which were presented by him to Cornell University. They came from a fine compact sandstone lying above the Chemung fauna. The sandstones exhibit traces of the same polished quartz gravel seen in the same layers of the Cuba sandstones.

Wellsville, Allegany County, N. Y,-492.

There is a quarry on the hillside at Wellsville a hundred feet above the railroad, the top reaching over 1,600 feet elevation above tide. In 
this quarry the prevailing rocks are a brownish gray sandstone, in not very thick courses, thin bedded micaceous shales, and soft, fragile olive shales, with an irregular seam of fossiliferous, red, arenaceous shale.

In the sandstone are -

Spirifera disjuncta, abun dant.

Productella hirsuta.

Ambocoelia umbonata.

A large, flat, fish scale, the surface broken off so that it cannot be determined; but the nature of the bone still preserved is like that of Holoptychius.

Ceriopora, sp., casts showing the form of branching, but no structure.

In the soft olive shales -

Rhynchonella contracta.

Productella costatula, var.

Ceriopora, same as above.

The red shales are oölitic in spots and also contain streaks of fine polished pebbles. The fossils are generally in imperfect condition; the fish remains are in broken fragments. The following species were recognized:

Spirifera disjuncta, rare.

Goniophora Chemungensis, small, and with rather coarse concentric striæ. Mytilarca, sp., small, and presenting characters between M. occidentalis and $M$. simplex.

Macrodon Chemungensis, small.

Grammysia communis.

A small Orthoceras, an Aviculopecten, a Crenipecten, and a small Palceo. neilo, none of them perfect enough for specific identification.

The branches of Ceriopora, sp., seen in the other shales, and among the grains a few minute spiral shells.

In the same quarry are seen layers, or rather large lumps, of a sort of pudding of white sand, mingled with small nodules of green elay and streaks of mica flakes.

This condition of rock appears to indicate a transition of conditions, in which considerable disturbance took place, but the break indicated was so slight that the mud at the bottom was still mud and not consolidated into rock when the sand was thrown down upon it.

Very similar characters were seen in the sandstone quarry at Arcade. The horizon of this quarry is considerably above that of the Cuba sandstones, but between it and the Wolf Ureek conglomerate.

Belmont, Allegany County, N. Y.-493.

This is the locality called Phillipsburg in the New York State geological reports, from which many species are quoted.

The sandstone, which is quarried in several places in the neighborhood, is light gray, calcareous, and with petroleum smell. It is underlaid by a soft, olive shale, as is the case with the Cuba sandstone. It 
lies at about 1,450 feet elevation and represents very closely the horizon of the Rockville sandstone, 479.

Some of the more common species are-

Spirifera mesacostalis, second and third varieties.

Orthis impressa, large.

Streptorhynchus Chemungensis

Rhynchonella contracta.

Grammysia elliptica.

Productella hirsuta.

Hornellsville, Steuben County, N. Y, -494 .

On my return eastward I stopped at Hornellsville, where I made an examination of some cliffs along the railroad west of the town, at which point is exposed a section of about a hundred feet, beginning at the base at 1,200 feet elevation, the railroad grade at the station being 1,161 feet above tide.

Running eastward along the Erie Railroad from Allegany County, the summit at Alfred, elevation 1,793 feet, presents some cliffs of heavy sandstones and shales which are well up in the Chemung; but as we go down the grade no strong sandstone layers are met with as far as Hornellsville, elevation 1,161 feet, and from there to Elmira, elevation 863 feet, the whole series is made up of alternate layers of arenaceous shales and stiff seams of thin bedded sandstone of a prevailing dark brownish gray, no light or pure grays appearing, -nor are there any of the gray sandstones marking the Upper Portage and Lower Chemung of the Wyoming-Allegany section.

For topographical and stratigraphical reasons I thought that at about this point, which is intermediate between the two long sections of Tompkins-Tioga Counties and Wyoming-Allegany Counties, would be found the horizon at which the Portage and Chemung faunas meet. Stratigraphically it should lie not far from the horizon of the Portage sandstones of Portage Falls, and for similar reasons, looking eastward, it should lie several hundred feet above the horizon of the Ithaca shales. Upon examining the rocks I found it even more important than I had expected. The general appearance of the cliff is very similar to those in Caneadea Creek below Rushford, but here there are none of the light colored sandstones of Allegany County.

The section (494 A) presents the following lithological characters and faunas from below upward:

(1) A stratum of very dark, almost black, shale appears at the base; this is lithologically identical with the upper black streaks underlying the Portage sandstones at Portage Falls.

(2) These black shales are followed by soft fragile shales, olive gray in color, and bearing a very interesting fauna, marking very decidedly the transition between the Portage and Chemung faunas. 
The species identified were the following:

Cardiola speciosa, common (=Glyptocardia spcciosa Hall, 1885).

Palconeilo plana, var. A small form frequently seen in the Portage shales; it appears indistinguishable from $P$. plana, except that in size it is much smaller

Coleolus acicula.

Coleolus (Coleoprion) tenuicinctum.

Fragments of a small Orthoceras and of Goniatites of the G. bicostatus type.

Productella speciosa, a single valve of small size.

Fragments of Cladochonus and of crinoid stems.

Orthis Tioga, several specimens, small, but with the characteristics of that species.

The Cardiola and the Palceoneilo of this shale (which are the principal fossils, the others being of rare occurrence) are identical with those of the last olive Portage shale of the section at Portage Falls, (see p. 51), and the whole fauna, except the Productella and the Orthis, is purely Portage in character.

(3) Above this are coarser shales and thin layers of argillaceous sandstone, staining brown in places, with occasional thin streaks of light or nearly white sand in the midst of the olive shales, just as they occur at station $476 \mathrm{G}$, in Caneadea Creek below Rushford, in which was found the earliest appearance of Chemung fauna for the eastern part of that section.

The fauna of this zone, $494 \mathrm{~A}^{3}$, was as follows:

Leiorhynchus multicosta, running into the form L. mesocostalis. Ambocoelia umbonata.

Productella speciosa, a few specimens.

Spirifera mesostrialis, a single specimen, but with the characteristic markings.

Spirifera mesocostalis, a single poor specimen

Orthis Tioga, larger than those below.

Rhynchonella Stephani?, a coarse variety approaching $R$. contracta.

This fauna is in its main features like a forerunner of the Chemung fauna occurring a few miles south of Ithaca, lying far above the Ithaca fauna. The Leiorhynchus and Ambocelia are the common species; the others are rare or seen in a few specimens. The list of species taken as a whole is similar to that of $476 \mathrm{G}^{0}$, at the base of the Chemung series in Allegany County, although the Orthis of that fauna is $0 . \mathrm{im}$ pressa, while this one is O. Tioga. This, however, is evidently a geographical feature, as the common species of Orthis in the Chemung faunas of Allegany County is Orthis impressa, while O. Tioga is the more common form in Tioga and Chemung Counties.

(4) Immediately following are more sandy layers, with Chemung fauna wherever fossils occur in them. 
In one slab several good Spirifera mesocostalis were seen, all marked with the strong median septum not dereloped in the specimens living at the Ithaca stage. This single section throws considerable light upon the history of the faunas we are studying. Geographically it lies between the two main sections already fully developed. One of the most striking differences between those two sections is seen in the interval between the Genesee shale and the zone containing the first Spirifera disjuncta.

In Wyoming County this interval is filled by a long series, of a thousand feet or so, of black and olive shales, containing respectively the Lingula fauna of the Genesee and the Cardiola speciosa fauna of the Portage, and is terminated by thick deposits of gray sandstone.

In Tompkins and Tioga Counties the black shales terminate a short distance above the Genesee; a special Portage fauna, the Spirifera lavis fauna, occurs near the base of the Portage; a few hundred feet higher a rich brachiopod fauna, that of the Ithaca group, occupied the field. While two or three hundred feet of sediments were depositing, this fauna withdrew and the Cardiola speciosa returned, and is occasionally seen in the almost totally barren, flaggy, arenaceous shales and sandstones, until at about the same distance above the Genesee shale, as in the more western section, the Chemung fauna begins to appear with the first Spirifera disjuncta.

The stratigraphical conditions help us very little in interpreting these differences, except that the coincidence of the occurrence in each section of the first good representation of the Spirifera disjuncta fauna in a bed of heavy calcareous sandstone is suggestive of a common borizon.

The fossils of the Hornellsville shales show us definitely where we are in the history of the faunas. Stratigraphically these shales are at the general horizon of the passage beds of Portage Falls, and, compared with the eastern section, near the point at which the genuine Chemung fauna first appears.

- The fossils show that the Portage fauna is still intact, even in the presence of a characteristic species of the true Chemung fauna, Orthis Tioga. The presence of this species, instead of 0 . impressa, shows that we are dealing with an eastern extension of the fauna. The spirifera mesocostalis, with strong median septum in the ventral valve, as well as the Orthis, is evidence that we are far above the stage of the Ithaca fauna.

Taking all the facts together, we could scarcely hope to find stronger confirmation of the hypothesis advanced in my report in U.S. Geological Survey Bulletin No. 3 that from a paleontological point of view the Ithaca group and its fauna are really intercalated in the midst of the deposits which in western counties are regarded as one continuous series on account of their fauna holding its integrity from the beginning to the close. I regard, therefore, the Ithaca fauna as a separate, earlier stage 
of the Chemung fauna, intermediate between it and that of the Hamilton group and occupying an intermediate position; while the special fauna of the Portage shales is a more general one, probably of partially pelagic character, less restricted in both geographical distribution and geological range, but during the Middle and Upper Devonian making its appearance where the conditions were unfavorable for the more vigorous brachiopod faunas, and rarely, except at points of transition to another zone, mingling with any brachiopod fauna. 


\section{CHAPTER IV.}

THE UPPER CHEMUNG - THE SANDS AND THE CONGLOMERATES.

As we pass above the principal Chemung faunas we find coarse, flaggy sands, red beds, and conglomerates. The conglomerates are of two kinds: The first is composed of smooth, gravel-like pebbles, with layers of flat pebbles, and is called the flat pebble conglomerate. The higher is composed of large, coarse pebbles, not much worn, and sand; this is the Olean conglomerate and its equivalents.

The exposures of these deposits were examined at Clarksville, 483 ; Little Genesee, 484; and Bolivar, 485, all in Allegany County, New York ; at Portville, 486; Olean, 487; Great Valley, 490, of Cattaraugus County, New York; and at Bradford, 488, and Alton, 489, in McKean County, Pennsylrania.

l'larksville, Allegany County.-483.

This station is six miles south of Cuba and upon higher ground, the hills running up to two thousand feet above tide level. The rocks exposed are of a geological horizon higher than the highest of the Cuba section, but the base of the Clarksville section is the same paleontological zone as that seen in the ravine south of Cuba ( $477 \mathrm{E}$ ).

In the township of Clarksville, including the upper part of Wolf Creek, where the flat pebble conglomerate is seen in full development, we find the passage from the olive shales and the thin bedded sandstones of the Upper Chemung, with their typical fauna, through the coarse, yellow sandstone and flat pebble conglomerate with an occasional jasper pebble, which, all through this region, is recognized as the first of the Devono-Carboniferous conglomerates, and thence up into the green and red, arenaceous shales and those green, micaceous shales, of a loose and mealy texture, so characteristic of the Catskill deposits farther east.

The lowest exposure ( $\left.483 \mathrm{~A}^{2}\right)$ examined in this locality was a ledge cropping out in a small run about half a mile northwest of the railroad station at an altitude of approximately 1,745 feet above the sea. Near this, in the same side hill, is the second exposure (483 $\mathrm{A}^{1}$ ), from nine to ten feet higher. The rocks at these exposures are green, argillaceous shales, with thin, flaggy sandstones and arenaceous shales with fossils.

The green shales $\left(483 \mathrm{~A}^{2}\right)$ contain the following species:

Rhynchonella contracta, numerous, large, and variable.

Leptodesma Mortoni, var., of the form of L. potens and L. Mortoni Hall, Plant remains, chips, and fragments of stems. 
In $483 A^{1}$, a few feet above $A^{2}$, the shales are more arenaceous and darker, are iron stained upon weathering, and, though they contain the same Leptodesmas, the principal fossils are brachiopods. The sandy layers are micaceous, and though dark hare a trace of the mealy texture peculiar to the green Catskill rocks as they appear farther east. One slab contains -

\section{Athyris Angelica.}

Leptodesma Mortoni, var.

Productella hirsuta, var, near $P$. hirsuta, but not the typical form.

Traces of Rhynchonella, sp., Spirifera, sp., and crinoid stems.

In other slabs Spirifera disjuncta, Athyris Angelica, and the Leptodesmas are associated.

Taking the species occurring within two or three feet of one another as of a single zone, we have the following fauna for $483 \mathrm{~A}^{1}$ :

Spirifera disjuncta, the most frequent species.

Athyris Angelica, common.

Rhynchonella contracta, small variety.

Leptodesma, sp., of the L. Mortoni type, some specimens approaching $L$. robustum and others $L$. potens.

And of the following species single specimens are rare: Spathella typica, Hall, distorted, resembling Nyassa arguta.

Mytilarca Chemungensis.

Productella costatula, var., a small form of the type of $P$. costatula.

A trace of a Pterinopecten, sp.

Sanguinolites rigidus (= Sphenotus contractus Hall, 1885).

?. Macrodon Chemungensis.

On the eastern side of the valley is a very steep, high hill, rising rapidly from the valley, and on its side the rccks occasionally crop out, not in solid strata, but in broken pieces, disintegrating rapidly, and partly covered by soil. The order of the rocks composing this hill is easily traced by these loose pieces on the surface, but it would not be safe to place any dependence upon the actual altitude of occurrence of any par. ticular stratum. This is $483 \mathrm{~B}$. The place for the lower conglomerate is between the base, about 1,880 feet, and the top, approximately 2,110 feet, in altitude, but I found no trace of the genuine conglomerate on it. The lowest rocks appearing contain the same fauna found on the other side of the valley, at $483 \mathrm{~A}$. The rock is a dark, arenaceous shale, micaceous in some layers and weathering brownish. At the base of the hill, and within the first 120 feet, the above are the prevail. ing characters and the following species were detected as constituting the fauna of $483 \mathrm{~B}^{4}$ :

Spirifera disjuncta, frequent.

Productella costatula.

Rhynchonella contracta, small var., and approaching the type $R_{*}$ duplicata.

Chonetes scitula, rare. 
WILLIAMS.] TRANSITION FROM CHEMUNG TO RED AND GREEN SHALES. 85

A small Chotetes, sp.

Orthis Leonensis, same as seen in the red beds of $477 \mathrm{E}$ and green shales of $477 \mathrm{H}$.

Mytilarca Chemungensis, small var.

Athyris? Angelica, probably A. angelica, but near the form of A. poitita. Sanguinolites clavulus (=Sphenotus clavulus Hall, 1885).

In the upper portion of this part of the section, $483 \mathrm{~B}^{4}$, traces of the conglomerate are seen in the form of fine pebbles, with oblique bedding on the ordinary dark brownish gray sandstone.

A slab, one side of which is thus turned into conglomerate, contains a fine specimen of Grammysia subarcuata. Another slab, with the same Grammysia, contains also some imperfect Rhynchonellas of the $R$. contracta type. Large oblique Leptodesmas, of the L. Mortoni type, appear in the same association.

Above these fossiliferous shales $\left(\mathrm{B}^{4}\right)$ occur light colored green shales, not calcareous, but breaking up into lumpy pieces. They are arenaceous and with streaks of the fine green mud shales $\left(\mathrm{B}^{3}\right)$. Above these are thin, fragile, red shales, first in thin streaks with the green, but the top of the hill is a rich red earth of several feet in thickness, composed of the disintegrated red shales.

As well as can be determined from surface indications the uppermost hundred feet is composed of alternation of the green and red shales, some layers micaceous and mealy, others fine red mud shale, constituting the specimens designated $483 \mathrm{~B}^{1}, \mathrm{~B}^{2}$, and $\mathrm{B}^{3}$ in the collections, and at an altitude from two thousand to twenty-one hundred feet above sea level.

It is perfectly evident on ascending this hill that we pass from the Upper Chemung zone through the zone which in other places is represented by a conglomerate, the first or flat pebble conglomerate, and pass upward a hundred feet at least into the estuary or brackish water deposits represented in the green and red shales, devoid of fossils and often micaceous and presenting the peculiar mealy appearance so characteristic of the barren measures which separate the typical Chemung deposits from the conglomerates, forerunners of the Coal Measures.

Ascending the hill on the west side of Centerville Valley, or Dodge's Creek, and passing over into the valley of Wolf Creek, on the eastern slope, we find the same conditions. At the base traces of the Chemung fauna are seen for one or $t w o$ hundred feet, then we run into the green and red shales, with traces of the flat pebble conglomerate intervening at an altitude of about 1,950 feet, above which the green and red shales hold on uninterruptedly to the top of the hill, over 2,100 feet high, and the micaceous structure is more frequent, with a tendency to form evenly laminated layers, separated by deposits of nearly pure grains of mica. As the mica grains are more abundant so also are they larger than in the rocks of the same horizon on the hill a couple of miles farther east. As we descend the western slope, into Wolf Creek Valley, we find traces of 
the conglomerate at the point of junction of the Chemung fauna bearing rocks below and the green and red barren shales above, and across on the west side of Wolf Creek Valley, near its head, is a fine representa tion of the flat pebble conglomerate.

The altitude of outcrop of this conglomerate on both sides of the hill is not far from 1,950 feet, and above 2,000 feet no conglomerate or frag. ments of it are seen. But in the small runs below this altitude large blocks of the coarse sandstone, merging into fine conglomerate, with streaks of larger flat pebbles, are frequent. On the extreme top of th3 hill, which by aneroid was estimated to be 2,250 feet above sea level, a loose block of nearly white sandstone with a few pebbles was found, but no outcrop. This may be a drift from the second conglomerate, but the several hundred feet of green and red shales below it preclude the idea of the occurrence of the first flat pebble conglomerate at this altitude.



This conglomerate is best seen near the head of Wolf Creek, over the hill directly west of Clarksville, or "Centerville Station." The main mass of it lies between 1,950 and 2,000 feet in altitude (aneroid estimate), and it may be fifteen or twenty feet in thickness; at no place were both top and bottom seen exposed. In the bed of the stream are large blocks of it from six to ten feet thick. Its general character is a coarse, loosely agglutinated, silicious sandstone, of a yellowish color, in some places stained strongly brown, at other places bleached nearly white, obliquely laminated, with the direction of the obliquity reversed sereral times during its deposition, containing streaks of coarser gravel, and occasionally becoming a thick mass of gravel and flat, white, silicious pebbles, with an occasional pebble of red jasper.

The fossils occur at or near the top, where the rock abruptly changes into the ordinary brown gray, arenaceous shales, with distinct traces of the Chemung brachiopod fauna again. The animal remains of the conglomerate, $483 \mathrm{C}$, constitute a characteristic fauna recognized in several other places under like conditions. At this locality numerous chips of carbonized wood were found, as well as the following species: Palceanatina typa, abundant.

Modiola prcecedens, common.

Cyrtoceros? Hector, several specimens.

Orthoceras? sp.=? O. Demus.

Goniophora Chemungensis, single specimen.

Leptodesma lichas? resembling L. lichas Hall.

Spiraxis? Randalli, var. Newberry. ${ }^{1}$

Spiraxis?, major Newberry.

${ }_{1}^{1}$ The name Spiraxis is preoccupied tor a genus of Gasteropoda, by C. B. Adams, 1850 . I propose, therefore, for this genus the name of Prospiraxis.

JUNE $1,1887$.

H. S. W. 
These last two peculiar spiral fossils are identified with Spiraxis described by Prof. J. S. Newberry in the Annals of the New York Academy of Sciences, Vol. III, No. 7, p. 220 (read December 10, 1883). Neither of them agrees precisely with the figures or specimens described by Professor New berry; but, as the specimens themselves are imperfect and from study of these and other known specimens it is found that the detailed characters presented by their peculiar forms are not uniform, it is believed that the truth is more nearly reached in referring them provisionally to these species than it would be if an attempt were made to make them the types of new species.

\section{Little Genesee, Allegany County, N. Y.-484.}

Genesee is the next township south of Clarksville and lies next to the State line. The "rock city" north of Little Genesee, $484 \mathrm{~A}$, is about five miles south and a little east of the Wolf Creek conglomerate exposure west of Clarksville, $483 \mathrm{C}$. On the southern slope of the hill on the top of which "rock city" is situated traces of the Wolf Creek conglomerate were seen in slabs and blocks between the elevations of $1,9: 5$ and 1,975 feet. The rock was not seen in place, but fragments of it were met several times along this zone and none above. The small flat pebbles were very distinct from the round and larger pebbles of the second conglomerate of the "rock city." Along the railroad, from Clarksville to Little Genesee, as well as in the sections on the hillsides, the series of strata were in the same general order as at Olarksville. No extended exposure was discovered where the precise thiekness of the individual masses.could be measured.

The Chemung fossils were rarely seen above the horizon of the first (Wolf Creek) conglomerate and but for a short distance. After the green, micaceous, and flaggy shales and the soft, red iron shales had fairly set in, the Chemung fauna ceased.

With the incoming of the second conglomerate of Little Genesee "rock city," there was deposited a coarse mixture of clay, iron ore, and yellow sand with fossils.

\section{DESCRIPTION OF RHYNCHONELLA ALLEGANIA.}

This ferruginous sandstone is characterized by a Rhynchonella of large size, differing from any species lower in the series, but it also contains frequent specimens of Spirifera disjuncta, linking its fauna with the Chemung fauna below. I propose to call it Rhynchonella Allegania, n. sp. Plate IV, Figs. 1-8.

This is a large rhynchonella, peculiar in this section to the coarse, ferruginous sandstones following the Chemung and found, generally, not far below the Olean conglomerate. It occurs in the form of empty

"The term "rock eity" is applied to the massive conglomerates as they appear capping the hilltops in several places in the southern counties of New York. In Cattaraugus County, six miles south of Olean, a station of the Olean, Bradford and Warren Railroad, built upon one of these "rock cities," has received the name of Rock City 
impressions in the coarse sand, but presents features separating it from the usual form of any of our Devonian rhynchonellas. Of the New York forms it approaches more nearly $R$. orbicularis or some varieties of $R$. Sappho. It appears identical in specific details with specimens I have seen in collections from Ohio marked $R$. Sageriana, but from the description of that species I believe it to be quite distinct. The costæ are more numerous than in the typical form of any of these species, from 10 to 13 being on each side of the center. It bears a close resemblance to some Eifelian varieties of $R$. laticosta, and the gutta percha cast of the exterior of a dorsal valve, represented in Plate IV, Fig. 3, is very close to R. princeps Barrande (Fig. 12, Plate CXX, Syst. Sil. Bohême). But after considerable study of the specimens and comparison with Devonian rhynchonellas I am led to the conclusion that it is scarely more than a varietal modification of the rhynchonellas from the ferruginous sandstones of Licking County, Ohio, called R. Sappho, var., by Prof. James Hall and figured in Geol. Surv. N. Y., Pal., Vol. IV, Part I, Figs. 47-52, Plate 55, p. 354.

In the form in which it is here represented it appears quite distinct, and I therefore propose the name Rhynchonella Allegania. The characteristics of this form are its large size, the broad, flat sinus and fold including five to seven well defined, rounded plications; the broad, flat, tongue-like platform representing a depression in the shell itself, under the beak of the ventral valve (PlateIV, Fig. 8); the well defined serrations of the cardinal teeth seen in Fig. 1; the presence of a strong but short median septum in the dorsal ralre (Figs. 1 and 4), with an elongated rounded beak of the rentral valie, perforated near the extremity (Fig. 7).

The specimens have been found in the ferruginous sandstones underlying the conglomerate at Olean and Little Genesee, in New York, and at Bradford, MeKean County, $\mathrm{Pa}$. In the larger forms the tongue shaped platform for muscular attachments in the beak of the ventral valve is rery broad and flat, giring a peculiar appearance to the casts, unlike the ordinary rhynchonellas of the Devonian.

The same rhynchonella occurs just below the Olean conglomerate at Rock City ${ }^{1}\left(487 \mathrm{~A}^{3}\right)$ in the same associations and in a ferruginous sandstone of the same character. On the way up the hillside to Rock City loose slabs were met with, though not found in place, presenting the same order of occurrence as at Clarksville.

Along the zone of the first conglomerate were found several slabs of the same character of rock and bearing the fossils of $483 \mathrm{~B}^{4}$, i. e., Grammysia subarcuata, and some specimens running into the G. communis type, as figured by Prof. James Hall, and Sphenotus clavulus, with one specimen closely approaching the form called Allorisma Winchelli of Meek. In these gray, shaly sandstones Spirifera disjuncta appears; also, Rhynchonella contracta. 
Flat pebble conglomerate also occurs here with Spirifera disjuncta, Rhynchonella contracta, with traces of a Bellerophon, sp., and a bryozoan. In this fine pebble conglomerate, fish teeth appear, one very similar to that met with in a similar conglomerate, found loose in the bed of the creek at Rushford = a Dipterus tooth (Dipterus? lavis Newberry); also conical teeth resembling those of Holoptychius ; but only the casts are preserved, so that it is impossible to identify them with certainty.

This section confirms the order of these upper rocks as interpreted at Clarksville. After the regular gray green shale of the Chemung, with its brachiopod fauna (rich in Spirifera disjuncta and often containing Rhynchonella contracta), has passed its meridian and is nearly terminated, a flat pebble conglomerate is deposited locally. Sometimes the conglomerate contains seams of large flat pebbles, at other places it is a thin stratum of fine, very hard pebbles, often containing black and greenish quartz, all highly worn and bearing fish teeth, together with Spirifera disjuncta, or, where the conglomerate is several feet in thickness, it is terminated by a coarse sandy deposit, with the unique fauna of Palceanatina typa and Mytilarca Chemungensis and Modiola proecedens, with Orthoceras and the peculiar coiled stems which Professor Newberry has referred to the genus Spiraxis. (See note, p. 86.)

Above this conglomerate it is rare to find any Chemung fossils, but they do not entirely cease till the second conglomerate of 484, Genesee "rock city," the Olean conglomerate. Between the two conglomerates are red and green, argillaceous shales (the former sometimes bearing Chemung fossils), with flaggy, micaceous, green shales and sandstones. The intervals between these two eonglomerates may arerage about three hundred feet, but the first conglomerate varies considerably in thickness and probably varies in the precise position it occupies in the series, since it probably represents a shore line which must have occupied consecutively a higher and higher position as the slow elevation brought it farther seaward from its earliest position.

Bolivar, Allegany County, N. Y. -485 .

The rocks about Bolivar were examined, and, although no extended exposures were met with, all the evidence obtained confirmed the order of the series as already given. Bolivar is about four miles east and perhaps two miles north of station 484, at the "rock city," Little Genesee. The region for a radius of a mile or more is perforated by oil wells, and although, as abore said, no good rock exposures were seen, there are along the steep hillsides slabs and broken pieces of rock which, from their very order alone, show that they are not far from their source. I collected the surface rock at various elevations on the hillside in the northern part of the town, on the "oil farm" of Varney \& Co., and, upon examining the material, I afterwards found it arranged in the same order as in other sections in the county. The elevations must be regarded as only approximate, but for general purposes they are valuable. 
Supposing the railroad station to be 1,600 feet in elevation, we find the greenish gray shales of the Chemung with some gray sandstone, containing Spirifera disjuncta, Rhynchonella contracta, and Sphenotus clavulus, up to 1,800 feet elevation. The flat pebble conglomerate occurs on the surface from this level upward for fifty feet, and in this conglomerate we still find spirifera disjuncta.

Above an elevation of 1,850 feet the coarser gray sandstones are more conspicuous, with red shales and mottled arenaceous shales; toward the top, or above an elevation of 2,000 feet, coarse, micaceous and ferruginous sandstones are the prevailing surface rocks. From such a series of specimens we recognize the general position of the section. It is substantially the same as that seen on the hill separating Clarksville from the valley of Wolf Creek (see section $483 \mathrm{C}$ ), but as a whole lies a hundred feet lower down. The position of the flat pebble conglomerate is between 1,800 and 1,875 feet in elevation, and at Clarksville it is near 1,950 feet.

I obtained from Mr. W. T. Reed, the obliging superintendent of the Varney \& Co. wells, the measurements from the mouth to the top and bottom of what are called by the oil men the "third sand," in this oil field being known as the "Richburg sands." As usual, the first oil sand is here regarded as lying about three hundred feet above the oil bearing third sand, although in drilling the place of the second was not clearly distinguished. Records of nine wells were given, the thickness of the third sand varying from thirteen to forty-seven feet. Taking the records as they are, measuring from the mouth downward, the top of the third sand does not vary over a hundred feet for the nine wells of which a record was made; but the average altitude of the top of the Richburg sand, for this lot of wells, according to aneroid measurements and estimates, is 800 feet above the sea, or something orer a thousand feet below the flat pebble conglomerate of the Upper Chemung.

The nature of the "oil sandstone" from well No. 11, at the level mentioned above, after shooting the well, is like the gray sandstones of the surface twenty or thirty miles farther north. It is calcareous and contains a few black grains as well as grains of mica. No traces of fossils were seen in it. It is probable that this sandstone is represented at the surface farther north by the Portage sandstones at Portageville, 482.

Portville, Cattarangus C'ounty, N. Y.-486.

This station is between Little Genesee and Rock City, Cattarangus County; and the "rock city" of Portville is directly west of Little Genesee "rock city," and between four and five miles distant. The top of the conglomerate (486 A) is at an altitude of approximately 1,850 feet, as determined by aneroid.

The fossils found at its top and the relations of the rock to those below and above leave no doubt of its indentity with the Wolf Creek conglomerate $(483 \mathrm{C}$ ) four miles to the north. We are able to trace the same 
zone in the side hill below the Little Genesee "rock city" and at Bolivar at approximately the same elevation.

The conglomerate is a massive, unevenly bedded, coarse, yellow sandstone, with a few pebbles scattered irregularly through the mass and some beds or layers of pebbles cemented by sand. At the top is a fos. siliferous layer containing numerous fossils, the most abundant being Palocanatina typa, with several species of mytiloid shells. The pebbles are of the lentiform shape so characteristic of these lower conglomerates, and jasper pebbles are found among them, as in the other flat pebble conglomerates.

Abore the conglomerate are dark, thinly and evenly bedded, micaceous shales, and within the next hundred feet are red, argillaceous shales and the greenish gray, micaceous shales characteristic of the deposits between the two conglomerates.

The species identified in this fauna, $486 \mathrm{~A}$, are -

Palceanatina typa.

Modiola procedens.

Mytilarca? sp.

Rhynchonella contracta, the ordinary type and a small variety:

Leptodesma? sp., a form near the L. lichas, Hall.

Orthoceras? sp., apparently identical with the species from the Wolf Creek conglomerate, $483 \mathrm{C}$.

No Chemung fossils were detected above the conglomerate.

Great Valley, Cattarangus County, N. Y.-490.

The flat pebble conglomerate forms a "rock city" about six miles south of Ellicottsville, on the ridge separating Little Valley and Great Valley.

The first trace of fossils in loose slabs under the conglomerate is of the same fauna which runs up to the conglomerate at Wolf Creek, Allegany County, and other places in the same region. But in Great Valley I found no fossiliferous ledges in place. The elevation of the top of this conglomerate has already been carefully determined by Messrs. Chance and Hall, and is 2,190 feet above sea level and thirty-five feet thick. (See Report IIII, Second Geological Survey Pennsylvania, J. F. Carll, p. 203.)

The rocks are the ordinary flat pebble conglomerate, with some ferruginous streaks, while the main mass of the rocks is a coarse, yellowish sandstone. The sands are obliquely bedded and the direction of this beach lamination is reversed several times during the formation of the deposit.

The characteristic jasper pebbles are also found; but no fossils were found in any part of the conglomerate.

In all the elements of composition, structure, and color, this corresponds with the conglomerates of Wolf Creek, Portville, and places in Allegany County. 
0lean, Cattaraugus County, N. Y.-48\%.

From Olean upward to the Rock City ${ }^{1}$ conglomerate, six miles south of the city, the Upper Chemung rocks are exposed in numerous places, clearly exhibiting the general sequence of faunas and stratigraphical characters.

Olean, at the Buffalo, New York and Philadelphia Railroad depot, is reported as 1,435 feet in elevation; 1,430 feet is C. A. Ashburner's corrected altitude.

The first exposures in the hillsides are of Chemung rocks, containing the Athyris Angelica fauna, and for fully two hundred feet, extending to 1,700 feet in altitude, the characteristics of the Upper Chemung are conspicuous. Although thin sheets of red, argillaceous shale are met with in the midst of the ordinary greenish gray, fossil bearing Chemung shales, they become more conspicuous, in thicker masses and associated with coarser, micaceous, flaggy, and barren shales, as we ascend above the fossiliferous parts. The highest exposure of a characteristic Chemung fauna was found in gray, arenaceous shales two hundred and thirty feet below the first sandstone and about four hundred and thirty feet below the base of the Olean conglomerate. A considerable bed of red shales occurs half way between the first sand and this top of the Chemung fauna.

The first sandstone, as determined by examination in several places, is not uniform, but lies between two hundred and two hundred and fifty feet below the base of the conglomerate. This is evidently the sandstone which the oil well drillers on top of Rock City speak of as occurring about three hundred and fifty feet from the top of wells started above the conglomerate. The rock as found in places is of variable character. Below Rock City on the west $\left(487 A^{5}\right.$ and $\left.487 A^{6}\right)$ it appears in a few courses, none of which exceeds eighteen or twenty-four inches, of tough, yellowish, fine grained sandstone; some parts of these are marked by the borings of some worm similar to the Fucoides verticalis in the Portage sandstones below, but not more than a quarter as large, and occurring in great numbers, so that exposed and weathered slabs show as many as fifty of the small pittings, due to the deeper weathering of their exposed ends, in the space of a square inch. The lower layers of the sand are generally a little coarser and looser grain, more or less brown iron-stained. Above and below, red, argillaceous shales occur with the ordinary greenish shales, but at this exposure no conglomerate or pebbles were detected. Around on the north side, at the Cook quarry, the same zone is recognized, and at very nearly the same eleva. tion, as determined by aneroid barometer. This is $487 \mathrm{C}$, the details of which will be given more fully beyond (p. 97). The particular sandstone in question is under a mass of red and green, argillaceous shales several feet thick; it is irregularly bedded, wedging rapidly in some layers from a 
thin streak half an inch thick to a bed two feet or so thick and massive. Associated with it are beds of flat and small pebbles, beds containing fragments of plants in abundance, and in the upper layers are the fine vertical borings seen in $487 \mathrm{~A}^{6}$ and also in the corresponding sandstones of Bradford, McKean County, Pa. The lower layers are of the more massive, fine grained, yellowish brown sandstone. The quarry, however, is principally worked for the excellent thin bedded, blue gray, micaceous flagstones lying below these yellow sandstones.

Above this zone of sandstone and conglomerate the rocks are green and red, coarse, mealy, micaceous shales and flags, and soft, argillaceous shales, until near the base of the conglomerate; where we meet the ferruginous sand stone containing the large Rhynchonella Allegania and the Spirifera disjuncta so characteristic of this zone.

Study of these sections and close comparison of the specimens from the various localities lead me to the opinion that serially there is a uniformity in the deposits for all of this region in Allegany and Cattaraugus Counties, however the minute details of the local sections may differ.

The characters marking the close of the Upper Chemung epoch are as follows: Deposits of thin bedded, alternating, argillaceous and arenaceous, bluish to greenish brown, fine grained shales containing the last Chemung fauna, with its characteristic variety of Spirifera disjuncta, with area high and overarching and not prolonged at the cardinal extremities, Athyris Angelica appearing in the softer, argillaceous deposits and Rhynchonella contracta.

As these conditions passed away the red shales gradually came in. These first occur as thin layers, appearing occasionally in the midst of the other rocks of soft, red shale; occasionally they contain one or two of the regular Chemung fossils. As we ascend, the red shales are accompanied by traces of the green, micaceous beds; but when the mica shales appear the fossils are very rare or wanting. When the prevailing character of the rocks is evenly laminated, loose textured, coarse grained, and micaceous, we look in vain for fossils:

At this stage in the sequence we look for the first sandy conglomerate. From examination of several sections in different places I am convinced that for these Southern New York outcrops, the first flat pebble conglomerate-carrying often jasper pebbles (with some variation in the thickness of the red shales abore the last Chemung fauna and some difference in the extent to which Chemung species run up in the red bearing rocks)-occurs stratigraphically at this place in the series. It is not always a pebble conglomerate, but when only a gritty sandstone it generally contains a few scattered pebbles, and though Chemung fossils may not have entirely ceased at its arrival it is very rare in this region to find any of the characteristic species above it.

Above the flat pebble conglomerates, the red and green, argillaceous shales and the gray, micaceous, and flaggy shales prevail up to the 
Olean conglomerate. In this interval are seen the coarse rocks which resemble the Catskill deposits of the eastern part of the State and contain Holoptychius and other fish remains. Just below the Olean conglomerate there is a ferruginous sandstone, as at Little Genesee, holding the same fauna, containing among other species the Spirifera disjuncta.

The Olean conglomerate is divided into two parts by a thin stratum of black shale, which doubtless represents the zone of the Marshburg upper coal or Sharon group of Mr. C. A. Ashburner (see Report of the Second Geol. Surv. Penn., R.); above this the conglomerate is less pebbly, the sandstone whiter and finer. This upper portion of the "rock city" section I regard as representing Kinzua Creek sandstone of the above mentioned report.

The records of oil wells drilled from the top of the Olean (Rock'City) conglomerate agree in their general features with the facts dereloped by study of the outcrops along the hillsides. The drillers report about eighty-feet, at the thickest point, for the conglomerate, including both members. At a depth of 350 feet they report the first strong sand seam of two screws' thickness; below this, "red streaks," but no thick red beds; at a depth of 1,250 feet is another sand of varying thickness, below which no red shales are found. Oil is struck in a sand at a depth of 1,860 to 1,865 feet.

Taking 2,340 feet as the altitude of the bottom of the conglomerate (see Report Second Geol. Surv. Penn., R), the top would be at 2,420 feet in altitude, and the first sandstone at 2,070 feet. The outcrop of this sandstone, as recognized on the hillside, was not so thick as the drillers reported.

At several places at about 250 feet, aneroid measurement, below the base of the conglomerate a massive sandstone was seen, varying greatly in thickness (see $487 \mathrm{~A}$ and $487 \mathrm{C}$ ). It is composed of a yellowish sand similar to that associated with the flat pebble conglomerates, with pebbles in some specimens. Along the hillside below this horizon were frequently seen large blocks of thick, massive sandstone of the same character, carrying traces of the same fauna met with in the flat pebble conglomerates farther north and east. These large blocks have been extensively used in and about Olean for building stone, and, although they are of an entirely different charac ter from the Olean conglomerate, the actual ledge from which they came is not known, even by the most experienced quarrymen of the neighborhood. From study of the region I concluded that they were probably represented by the thin sandstone called $\mathrm{C}^{3}$ and $\mathrm{C}^{6}$ in the Milo Cook quarry. The blocks were found in several places nearly as high as this quarry and scattered on the hillside at all altitudes below, but I did not find one above. The wedge shaped beds of sandstone in that quarry explain the probable nature of the deposit thronghout. It was doubtless thick and thin, as coarse sand might be expected to be deposited near a shore, with soft shale partings, which broke up the massive character wherever they were fre- 
quent or in thick layers. The more massive beds, when two or three feet thick, stood out during the general disintegration of the hillside, and breaking off finally rolled down the hill, but the massive portions were not continuous or uniform for any distance, and no regular ledge of the rock is detected along the slope of the hill. Seen along the hillsides at about the same horizon and loose below and reported at approximately the same position in the series by the well drillers, and by them found to be the only sand worth mentioning until passing below the red shales, these yellow sandstones show traces of both the flat pebbles and the fauna of the genuine flat pebble conglomerate, and they are the only rocks between the typical Chemung faunas and the Olean conglomerate which bear any resemblance to that zone.

I conclude therefore that, for the Olean section, these yellow sandstones are the representatives of the Wolf Creek, the Portville, and similar conglomerates farther north, east, and west, although they lie apparently higher stratigraphically in relation to Chenung marine faunas and in a more pronounced setting of red shales and green, micaceous shales than do any of the flat pebble conglomerates farther north and west.

This interpretation is further supported by comparison with the sections farther south and east, where the red and green shales and the coa rser, micaceous deposits become more and more frequent and of greater thickness previous to the deposit of the great conglomerate, and as we go off in the southeastern direction the flat pebble conglomerate appears to lose its identity in the general increase of coarser deposits all through this part of the series.

\section{Section 487 B.}

Along the railroad, ascending the hillside from Olean toward Rock City, the rocks for the first hundred feet are gray, arenaceous shales and shaly sandstone, with some layers of softer, greenish, argillaceous shale, such as is common in the Chem ung group. Rising above this, traces of the red shales appear. The lowest clearly marked red shale was seen at about 1,650 feet elevation, or something over two hundred feet above the valley, in the midst of ordinary shales with Chemung fauna. This is at an elevation but a few feet lower and in the same lithological associations as the first clearly defined red band of the section south of Cuba, $477 \mathrm{E}$.

The Chemung fauna, however, is not recognized much above this red shale; the species are very rare, and the fauna was rapidly disappearing when this six inch stratum of red shale was deposited. This Upper Chemung fauna is clearly marked by the prevailing presence of Athyris Angelica, the smaller variety of Rhynchonella contracta, and Productella of the type of $P$. hystricula. The Spirifera disjuncta is here the variety with high, overarching beak and narrow form. 
The fossil bearing, arenaceous shales are frequently strongly calcareous, and upon weathering, by solution of the fossils and the calcite, they become cavernous and often are stained brown by iron.

The fauna, as well as the general character of the rocks, shows this series to belong to the same general zone as that represented in the sections south of Cuba, particularly $477 \mathrm{E}$. The fauna is that which followed the Cuba sandstone, $477 \mathrm{~A}$.

Fauna of $487 \mathrm{~B}, \mathrm{H}$, \&c. :

Rhynchonella contracta; the large form is rare.

Rhynchonella contracta, var. saxatilis. This small form is the common one, and some varieties approach the form called $R$. duplicata Hall. Athyris Angelica, with some small varieties approaching $A$. cora and $A$. polita.

Spirifera disjuncta. The prevailing form is that of the short, high. beaked type, of small size, figured in Geol. Surv. N. Y., Pal., Vol. IV, Pt. I, pl. 42, figs. 1, 2.

Productella hystricula. The larger specimens approach more nearly the typical form of $P$. spinulicosta (or P. Shumardiana) and P. hirsuta and $P$. onusta; but the large majority of specimens are small, the ventral valve alone greatly resembling that valve of $P$.dissimilis Hall of the Iowa Devonian and the Lower Chemung beds of New York.

Ceriopora, sp. The hollow casts left by solution of the substance of the organism are frequent, but in such a condition as to forbid certain specific identification.

Sanguinolites clavulus, several specimens, (= Sphenotus clavulus Hall, 1885).

Sanguinolites rigidus, or varieties of the other form.

Leptodesma potens and varieties in the direction of the forms $L$. Mortoni and L. Maclurii.

Mytilarca Chemungensis, a single specimen.

Fragments of fish bone.

Plant fragments.

Fragments of crinoid stems.

A small, low coiled gasteropod, too imperfect to identify.

A fragment, probably of Schizodus rhombeus, but not distinct.

In the greenish shales at the foot of section $487 \mathrm{~A}$ (the stratum $\mathrm{A}^{9}$ ) the fauna is apparently the upper part of this same zone, the one seen at Clarksville and Portville just below the flat pebile conglomerate. This is made up almost entirely of Spirifera disjuncta, with a few Rhynchonella contracta, normal size, and a few Chonetes scitula of the later type. This part of the fauna was not reached in section B. In these upper fossiliferous strata the absence of certain species is worthy of mention: Streptorhynchus Chemungensis and Orthis Tioga and the Orthis of the first red beds above the Cuba sandstone are none of them present in these Olean shales. 
The arenaceous character of the strata has become prominent, and from this point upward the argillaceous shales are generally red or red alternating with a bright green and contain no marine fauna.

Cook Quarry, south of 0lean.-487 C.

This quarry exhibits some points of interest. The base of the quarry is somewhat over 200 feet below the base of the conglomerate at Rock City. ${ }^{1}$ It includes the same zone recorded as $A^{5}$ and $A^{6}$ in the section going down the slope westward from Rock City. It is also the same zone in which occur the last (on ascending) blocks of the fine yellow sandstone extensively used for building at Olean.

Mr. Milo Cook, the owner of the quarry, told me that he had searched in vain for the outcrop of this thick bedded sandstone. His quarry contains a few thin seams of like sandstone, but the main quarrystone is flagging of very fine quality, separated by thin layers of mica and cleaving into large, even flagging stone. The quarry exposes 50 feet of strata for minute examination.

The top of the cliff is covered with earth, lying upon-

$\mathrm{C}^{1}$. Three to four feet of red, argillaceous shale, soft and compact.

$\mathrm{C}^{2}$. Two to three feet light green, argillaceous shale, grading above gradually into the red.

$\left.\begin{array}{l}C^{3} \\ C^{4} \\ C^{5}\end{array}\right\}$

$\mathrm{C}^{3}$. Heavy bedded, gray sandstone, with some mica, but working pretty free; in the thickest part are courses of over a foot thick, from two feet running out to ten or even six inches.

$\mathrm{C}^{4}$. Thin stratum of fine grained, argillaceous shale, light green, similar to the lower part of $\mathbf{C}^{2}$.

$\mathrm{C}^{5}$. Coarse sand, yellowish color, filled with fragments of fossil wood and plant stems of Ptilophyton and Rhodea, \&c., containing pebbles in streaks, flat, and one of them an inch in diameter. This mass is very unevenly bedded and is broken up occasionally by thin sheets of the fine green shale.

${ }^{2} \mathrm{C}^{6}$. Coarse to fine sandstone, in some parts nearly white, very hard, silicious sand, the upper layers perforated by fine vertical borings filled by the fine green clay shale; surface when weathered pitted by the open mouths of the perforations; ripple marked in some places, with flat pebbles and a few plant fragments, as in $\mathrm{C}^{5}$. This mass is very uneven; in this one quarry it thins out from four feet to less than an inch in thickness. At this thin edge it lies between sandy shales, with plant fragments and soft, green, mud shale, is folded into regular undulations or furrows

${ }^{1}$ This Rock City' is a station on the Olean, Bradford and Warren Railroad, six miles south of Oleav.

Ball. $41 \longrightarrow 7$ 
about an inch and a half apart, the effect of ripple action, and is completely perforated by the small rertical borings above referred to. This is terminated below by a few inches of green - argillaceous shale.

$C^{7}$. Thirty-five feet dark bluish gray, evenly bedded, micaceous sandstone, very flaggy, cleaving into broad sheets, from one-half inch to six inches thick, the partings glistening with mica. About half way down (sixteen feet from top) is a thin parting of soft, red shale.

$\mathrm{C}^{8}$. Below the bottom of the quarry, at least ten feet, rock of the same character as $\mathbf{C}^{7}$, but coarser and unevenly bedded, showing current action, with oblique bedding, the direction of obliquity changing several times in course of the deposition of five feet.

The break between $\mathrm{C}^{7}$ and the sandstones above is very marked. The sands above are of light color, yellowish and brown gray, with traces of iron stain. Flat pebbles are frequent, though not here found in any large quantity. Although grains of mica are seen, they are merely peppered through the mass of the sand and not spread out in even sheets. The lower sandstones are dark bluish gray, with thin, flaggy bedding, no browning or iron stains, deposited in very smooth, thin sheets with partings of mica grains, making excellent flagging. The better part of the sandstones $\mathbf{C}^{3}$ and $\mathbf{C}^{6}$, especially the latter, are similar and equal in quality to the blocks obtained abundantly in the valleys and upon the hillside south of Olean.

The same characters and order of sequence were seen in the section on the hillside westward below Rock City. Bęlow a red, argillaceous shale, $\mathrm{A}^{5}$, came the thick courses of $\mathrm{A}^{6}$, with the same fine vertical borings at the top. The sandstone is of the same color and texture as $\mathrm{C}^{6}$, and below this for fifty feet, more or less, the prevailing rock is the mealy, micaceous flagstone represented by $\mathrm{C}^{\top}$. The elevation is approximately identical as determined by aneroid.

Comparing the lithological characters with those of the flat pebble conglomerates farther east at Portville, at.Clarksville, (Wolf Creek), and at Little Genesee, also with that farther west and north, the "rock city" of Salamanca, there is little to distinguish them. Looked at stratigraph. ically, this is full a hundred feet above the Wolf Creek and equivalent flat pebble conglomerates; but; when we examine the sequence of the faunas, this is the first genuine conglomerate, terminating the Chemung fauna and separating it from the typical red and gray shales of the Catskill conditions. On passing southward along this meridian we find the reds, in relation to the composition of the embedded faunas, taking a lower and lower place in the series, and they become more frequent and thicker; also the gray and green, micaceous flags, presenting a coarse and mealy appearance from the larger size of mica and sand grains, are more frequent and more fully take the place of the finer green and brown 
Chemung shales the farther south we go. We also meet more frequently single pebbles in the ordinary fossiliferous shales going the same direction. All these facts point to an approach to the shore line and shallower water. Associated with this change we should expect thicker deposition for each of the strata, and hence the upper strata should not exhibit so great a dip sonthward as the lower. Thus, in attempting to solve the problems of equivalency between the New York sections of these rocks and those farther south in McKean County, Pennsylvania, I trust to this line of interpretation, based upon the following fundamental proposition, which I believe to be substantially sound: That, for deposits within a single geographical area presenting varying conditions in the nature of the deposits and in the fossils, a more reliable guide for determining equivalency will be found in the continuity of a well marked fauna with persistence of slight varietal characters, than in any uniformity, either in the nature of the sediments, or in their thickness, or in their order of sequence, except for very short distances of separation. And, in general, the coarser the ingredients composing them, the more restricted geographically will be found the specific characters of a continuous deposit.

A mile or so beyond Rock City the upper member of the conglomerate $487 \mathrm{~F}$ appears. There are twenty or thirty feet of this sandstone here exposed, which I regard as the representative of the Kinzua Creek sandstone of the Report of the Second Geol. Surv. Penn., R. It is here a coarse sandstone, with few or no pebbles; in the upper layers, particularly, it is purer white than the Olean conglomerate below. Atits base I detected streaks of ferruginous shale and sandy shale, and at a point somewhat northeast of the Rock City station, on the top of the Olean conglomerate, I obtained some pieces of slaty coal and arenaceous shale, which Mr. Milo Cook, of Olean, informed me he himself saw dug out in making an excavation when the roads were being cut at the first oil excitement in this region. At that time he saw this black shale in place, and there were some two or three feet of the black shale with streaks of coal, which at the time caused hope of finding coal, but the digging revealed no solid coal, so the search was abandoned. The samples of this shale are marked $487 \mathrm{E}^{2}$, and attention is drawn to them as marking the horizon of the Marshburg coal of Mr. Ashburner's report. The whole mass of upper sandstone is of a white color, free from iron stain, and contains little cementing material, and what there is of it appears like fine clay or decomposed feldspar.

Several large stems were seen in this sandstone; one is a fragment of a Sigillaria stem.

The lower member, or true Olean conglomerate, corresponding to the conglomerate so defined in McKean County, is better defined as a coarse conglomerate with a sandy matrix and occasional streaks of sand. 
Bradford, He Kean County, Pa.-488.

After the careful and exhanstive work of Mr. Ashburner in MeKean County it would be difficult to add much to the stratigraphical geology of this county as set forth in Report Second Geol. Surv. Penn., R. Mr. Ashburner in 1880 found the rocks from the Olean conglomerate to the bottom of the deepest valley, paleontologically considered, essentially one group, incapable of subdivision (op. cit., p. 292, § 388). But paleontologically the strata are certainly poorly provided with means of discrimination. As, however, the sections in this county, and especially the Dennis well section near Bradford, are authoritative and are extensively used for comparison, I took some pains to locate the fossiliferous zones of the corresponding series of Southern New York in this rock series exposed at Bradford. L examined such rock outerops as I conld find from the valley up the side of Mount Raub to the Olean conglomerate capping it. This is section $488 \mathrm{C}$; also along the hillside towards the Dennis well, $488 \mathrm{~A}$. The materials collected, while not extensive, were sufficient to illustrate the general succession and position of the several fossiliferous zones. In the valley $(1,440$ feet at the railroad depot) and running up a couple of hundred feet are found the characteristic bluish gray, argillaceous and sandy shales and the thin sandstones of the Upper Chemung horizon, and in them, abundantly in some of the layers, the species of the upper fauna of the Chemung group.

In $488 \mathrm{C}^{8}, \mathrm{~A}^{1}$ and $\mathrm{B}^{1}$, are seen the following species :

Spirifera disjuncta, with high, overarching area.

Rhynchonella contracta.

Productella arctirostrata, running into the type of the var. lima of $P$. lachrymosa, are the more common forms.

Ceriopora, sp.

Fragments of crinoid stems.

Leiorhynchus? globuliformis, or one of that type.

Leptodesma, near L. Mortoni Hall.

Grammysia communis.

Palceoneilo.

This is the combination of forms frequently met with in the softer shales of the upper fossiliferous zone of the Chemung. Above this are red shales, gray and green, micaceous, flaggy shales, and sandstones.

A hundred feet or so above the last traces of this Chemung fauna a fine sandstone $\left(\mathrm{A}^{3}\right.$ and $\left.\mathrm{C}^{6}\right)$, with the small rertical wor $\mathrm{m}$ borings near the top, is clearly distinguished in both sections. This is mainly com posed of sand, but also contains stratified layers of pebbles. The pebbles are generally small and smoothly polished, with a few larger flat pebbles and an occasional jasper. This I interpret to be the stratum No. 15 of the Dennis well, described as "S.S. gray, fine, mixed with slate, a. few pebbles, specs. 26,$27 ;-23$ feet, elevation 1,817 to 1,840 feet, and referred to the Red Catskill group" by Mr. Ashburner. (Op. cit., p. 288.) 
At this żone a few fossils were detected, enough to show to what fauna they belong:

Spirifera disjuncta.

A small fish tooth.

A Leptodesma of the L. Mortoni type.

Palocanatina typa.

A cast of a lamellibranch, resembling Schizodus oblatus, but too imperfect for identification.

There is no place in the more northern sections to which such a fauna in such a rock can be referred, except the flat pebble conglomerate. Between this and the Olean conglomerate the prevailing characters are red and gray shales, greenish, micaceous, thin bedded shales, and sandstones. Not far above the sandstone $\mathrm{A}^{3}$ and $\mathrm{C}^{6}$, at $\mathrm{C}^{4}$, Holoptychius scales and Sauropterus ITaylori were found in thin bedded, shaly sandstone. Above this the only fossiliferous stratum detected is a band of ferruginous sandstone, $\mathrm{C}^{3}$, in which were found the Rhynchonella and Spirifera characteristic of a similar ferruginous sandstone underlying the conglomerate at Olean and at Little Genesee.

In the present section this sandstone is separated by over fifty feet from the base of the conglomerate, and it is apparently in the horizon called by Mr. Ashburner the sub-Olean conglomerate of the Dennis well section; but it is not a conglomerate, nor did I discover any stratum of conglomerate except the one mentioned above on the hillside of Mount Raub. The Olean conglomerate is clearly represented at the top, having the same characters as at Olean.

Whatever may be said of the differences between the stratigraphical conditions of this Bradford section and the corresponding five or eight hundred feet under the Olean conglomerate of Rock City, I am persuaded that the sequence of faunas was the same in both cases. The faunas are sparse, both in species and in individuals, but they are clearly recognized in the same order of succession as that borne by them in the sections fartner north. They are not confused: Spirifera disjuncta, though found at each zone, presents varietal characters, clearly distinguishing the upper zone from those below. The Lower Chemung form is of the narrow type, with short or rounded cardinal extremities, with high, overarching beak, strong dental lamellæ, and strongly defined fold and sinus, the front produced, as in Figs. 1, 3, 11, 16, and 17 of Plate 42, Geol. Surv. N. Y., Pal., Vol. IV, Pt. I. This type prevails up to the zone of the flat pebble conglomerate, where it is occasionally seen. But in the ferruginous sandstone under the second Olean conglomerate the elongate ty pe occurs, with mucronate cardinal extremities, the plications rather finer, the fold and sinus less strongly defined, the front not produced, approaching the typical characters of the Carboniferous S. striata.

I have called them all Spirifera disjuncta because a study of the forms appearing in the successive zones, as they are traced step by 
step, presents variations which link the prevailing type of one zone with the prevailing type of the succeeding zone. There is a variety in the Upper Chemung faunas which is indistinguishable from some speci. mens of the Iowa Spirifera Whitneyi, but its associations show, indisputably, that it is but a variety of $S$. disjuncta of our Upper Devonian.

Similar statements may be made in respect to many other species, but since it can be plainly demonstrated that the prevailing characteristics assumed by a species at one stage are very frequently, to say the least, not those assumed by it at the next succeeding stage, it will certainly lead to less confusion to use present specific names with some elasticity until the laws of modification shall be clearly distinguished in their relations to both geological range and geographical distribution. At the same time it has been my intention in these preliminary papers to point out any marked variation from the prevailing characteristics of species recorded.

The stratigraphical conditions are not uniform for the Bradford and Southern New York sections. In the Bradford sections there is a greater preponderance of red shales and green, micaceous, flaggy sandstone. Taking, however, the Olean conglomerate above and the gray and green shales with Chemung faunas be̊low as two well defined boundaries, the differences in the intervening deposits for the northern and southern sections seem to me to be best explained as geogr aphical variations in the nature of synchronously deposited sediments. Uniformity in the faunas and in the order of their appearance should testify more positively for equivalency of horizon than difference in the nature of the deposits should against it.

Alton, MeKean County, Pa.-489.

The rock exposures south of Bradford leall rapidly up into the cunglomerates, and in Lafayette Township we reach the first heavy cual seams of this area.

At Alton and at Buttsville I made a rapid survey of the sandstone and coal deposits and gathered materials for comparison with the sections farther north. No fossils except coal plants were detected. In the coarse sandstone underlying the first Alton coal are coarse stems of Sigillaria, apparently identical with those of the upper member of the Olean conglomerate at Rock City.

In regard to the lithological and stratigraphical featur es of this region little can be added to the excellent work of Mr. Ashburner (see Report Second Geol. Surv. Penn., R.). His Kinzua Creek sandstone is evidently the representative of the upper member of the Olean conglomerate, and the thin mass of black shale and shaly sandstone separating the conglom. erate from the coarse sandstone capping the "rock city" represents the Marshburg upper coal of the Pennsylvania reports. The representative of the Olean conglomerate in Lafayette Township I found less massive and with smaller pebbles than the characteristic Olean conglomerate of 
Rock City, Cattaraugus County, N. Y., or than that on Mount Raub, above Bradford.

The elevation of the bottom of the Olean conglomerate at Alton is 1,878 feet and at Buttsville 1,924 feet, as given by Mr. Ashburner (op. cit., p. 185). This gives an average dip of about twenty-fire feet to the mile from Rock City southward, which agrees with the estimates I had made of the average dip of the upper strata in Allegany County. From all the evidence accumulated from surface exposures and position in the salt wells of Wyoming County of the Corniferous limestone from Genesee County to the edge of Allegany County the average dip is not far from fifty feet to the mile.

\section{CONCLUSIONS.}

Prof. I. C. White, in the Keport of the Second Geological Survey of Pennsylvania (QQQQ, p. 77), calls the sub-Olean conglomerate of Mr. Ashburner the equivalent of his Shenango sandstone, and, as a sandstone, puts it in the midst of equivalents of Cuyahoga shales of Ohio. The shales below it graduate eastward into the Pocono groups. A study of the reports of Messrs. White and Ashburner, taken with my own examination of the rocks about Bradford, suggests the following conclusions:

(1) The Olean conglomerate is the equivalent of beds lying under the coal in Pennsylvania.

(2) There is a second conglomerate, with flat pebbles, under the Olean conglomerate, which must be regarded as of wide extent.

(3) The Pennsylvania geologists regard this lower flat pebble conglomerate (the "sub-Olean," "sub-Garland," \&c.) as lying under the "Catskill" and in the midst of deposits equivalent to the Lower Carboniferous beds of Ohio and the West.

(4) It is recognized by them as lying in the midst of the Pocono group of the Eastern Pennsylvania section.

(5) My section shows it to be at the top of the Chemung and containing a fauna of decided Chemung type, which is distinct in some features, but appears in the shales below.

(6) These underlying shales in New York gradually run into genuine Chemung rocks and fauna and cannot be discriminated from them by any sharp line of distinction.

I have traced the conglomerate and the faunas coming up to it continuously from north to south and observe $(a)$ an increase of green, micaceous slates, $(b)$ the appearance of red shale (1) lower and (2) thicker, and $(c)$ the sand deposits more conspicuous the farther south the section is made.

I conclude, therefore-

(7) That with the geographical passage sonthward the Upper Chemung beds grow coarser in their sands, the argillaceous bands become more micaceous, and the red bands are intercalated, and are present lower in the series; 
(8) That probably the same thing occurred in regard to the higher deposits of the Carboniferous;

(9) That the total deposits were thickened on passing southward by increase in the coarse sands, but that the red and green shales may only take the place of the brown and blue shales farther north;

(10) That the sands are purer and whiter by becoming coarser and freer from the brown clay and mud forming the ordinary shaly deposits of the Chemung, in New York;

(11) That with the purer deposit of sand the sands themselves become more massive, and are thus more easily distinguished as sands from the shales between; and

(12) That the increased thickness of the total mass affects the dip of the rocks based upon that of the Corniferous, so that the upper strata are more nearly horizontal over Southern New York and Northern Pennsylvania.

(13) I judge from the numerous facts here arrayed that the conditions for the deposition of red shales were not congenial to the marine fauna of the Upper Chemung group. So long as they were but temporaryrepresented by thin layers or occasionally intruded in the midst of the ordinary green shales - the Chemung fauna was only temporarily disturbed by their presence, but when they became the prevailing sediment, associated with micaceous, flaggy sandstones and green shales, the Chemung fauna departed. 


\section{P LA TES.}

(585) 


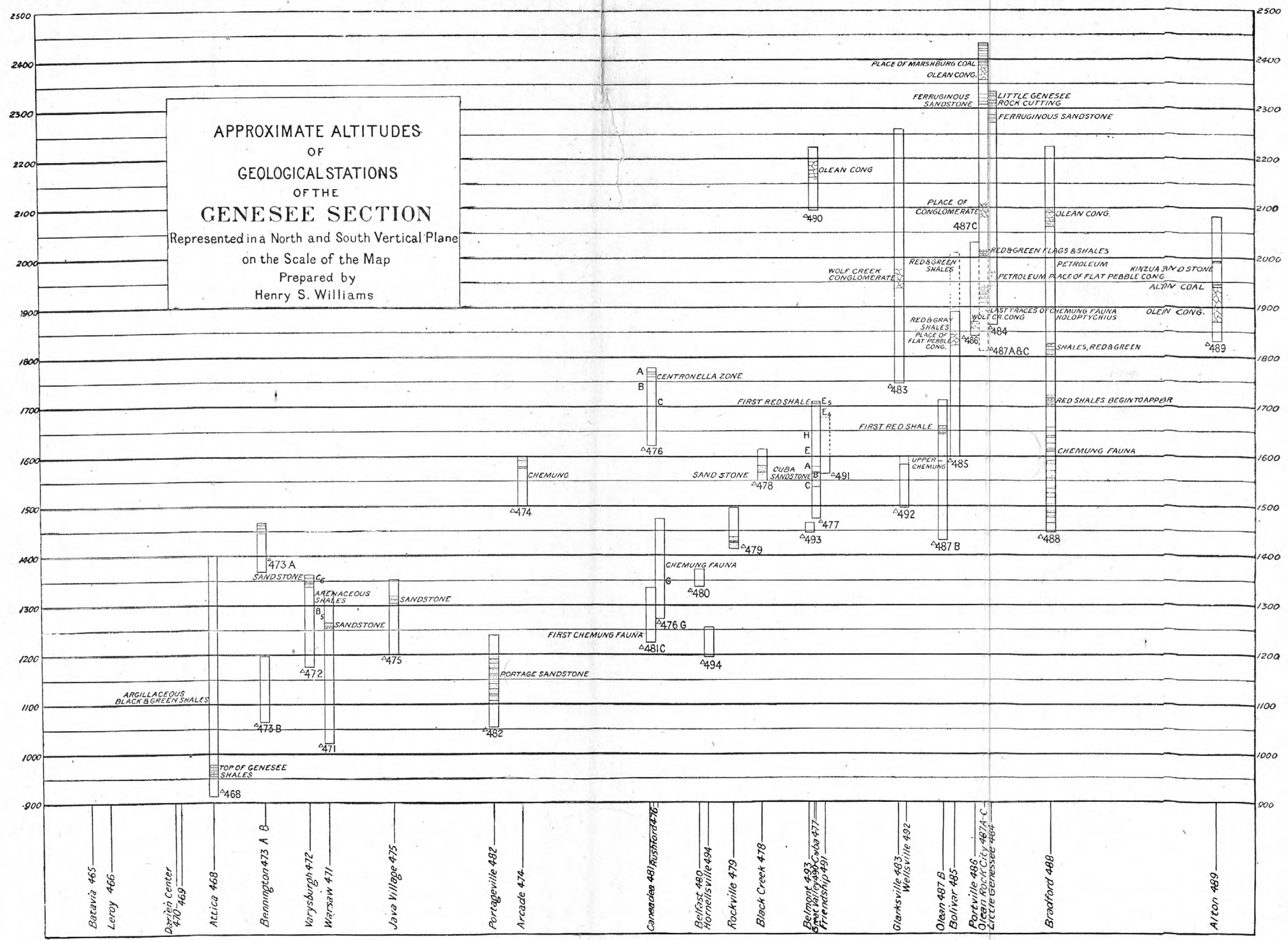




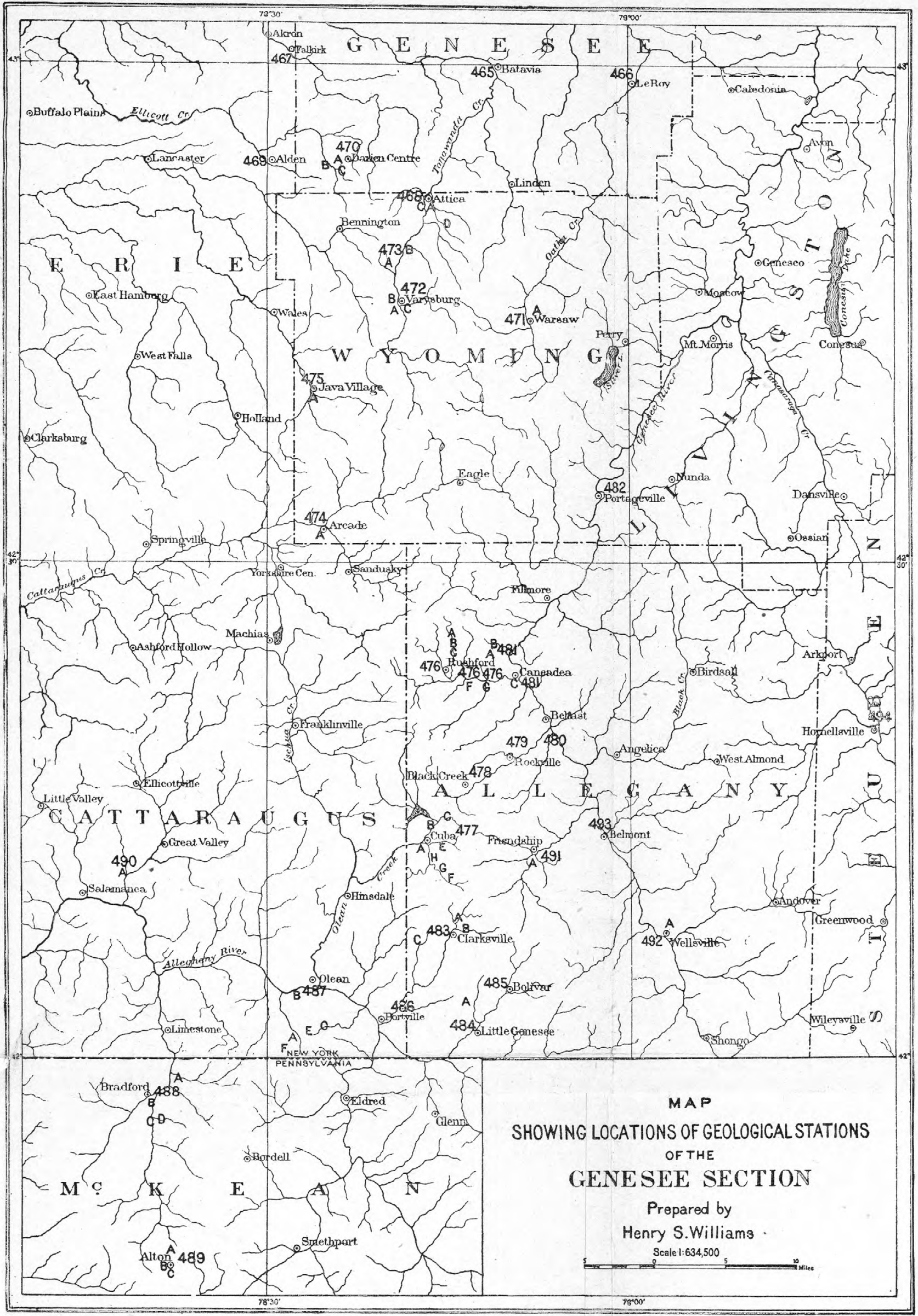






\section{EXPLANATION OF PLATE III.}

Frg. 1. Dipterus Nelsoni Newberry, ms., from the conglomerate of the Upper Devonian, near Rushford, Allegany County, N. Y

2. Dipterus? lavis Newberry, ms., from the Chemung conglomerate, at Little Genesee, Allegany County, N. Y.

3. Aptyohus of Goniatites, $\times \frac{2}{1}$, fromthe Portage shales at Attica, Wyoming County, N. Y.

4. Aptychus of Goniatites, $\times \frac{2}{1}$, from the Portage shales, Warsaw, Wyoming



5. Lunulicardium levis, $\mathrm{n}$. sp., right-valve, from the green Portage shales, Varysburg, Wyoming County, N. Y.......................

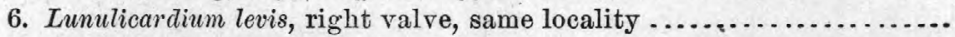

7. Lunulicardium fragile Hall, same locality ........................

8. Lunulicardium levis, n. sp., left valve, from the Portage green shales, Warsaw, Wyoming County, N. Y. (This and Fig. 6 are the types of

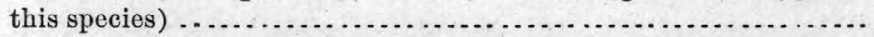

9. Ptychopteria? mesocostalis, n. sp., $\times \frac{2}{1}$, from the Portage shales; War-

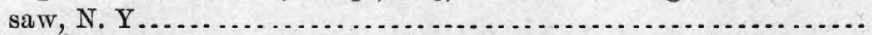

10,11. Pterinopecten? Atticus, n. sp., right and left valves, $\times \frac{2}{1}$, from the

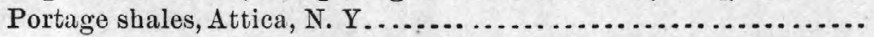

12. Ptychopteria mesocostalis, var., left valve, from the Portage shales, At-

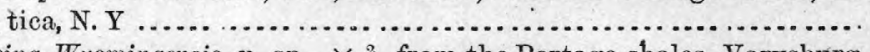

13. Lucina Wyomingensis, v. sp., $\times \frac{2}{1}$, from the Portage shales, Varysburg,

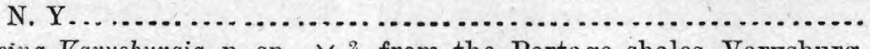

14. Lucina Varysburgia, n. sp., $\times \frac{2}{1}$, from the Portage shales, Varysburg,

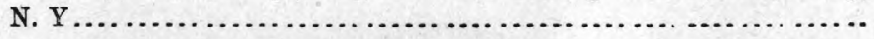



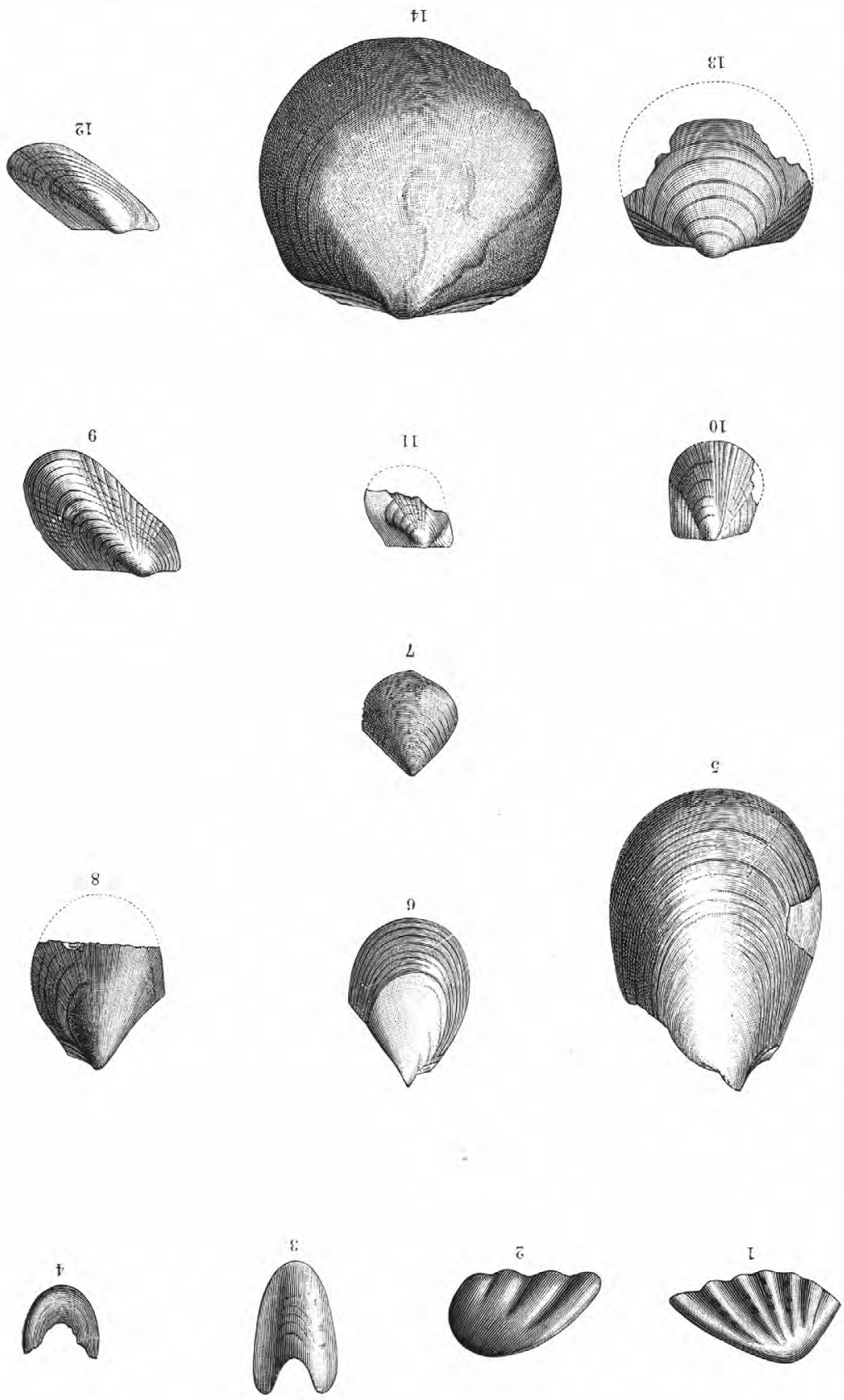




\section{EXPLANATION OF PLATE IV.}

\section{Page.}

FIG. 1. Rhynchonella Allegania, n. sp., dorsal view of interior impression, from the ferruginous sandstone below the Olean conglomerate, Little Genesee, Allegany County, N. Y..........................

2. Rhynchonella Allegania, lateral view of an interior impression, from the



3. Rhynchonella sllegania, ventral valve, taken from a gutta percha impression, from the same locality . .........................

4. Rhynchonella Allegania, dorsal view of an interior impression, from the samè locality ........................................ 87

5. Rhynchonella Allegania, side view of same specimen ................

6. Rhynchonella Allegania, a ventral valve, interior impression, from the same locality ......................................

7. Rhynchonella Allegania, showing deltidium, beak, and foramen, from a gutta percha impression ...............................

8. Rhynchonella Allegania, interior of ventral valve, an impression somew hat distorted......................................

9. Arenicolites duplex, n. sp., $b$, lateral view and $a$ showing a transverse section across top of $b$, from the Portage shales, Varysburg, N. Y... 



5

3


7 



\section{- I N DEX.}

[Figures in heavy face indicate the page on which the description occurs or important mention is made.]

\section{A.}

Allegany County, sections and exposures in, 20, s9.

Chemung rocks of, 51 .

Portage rocks of, 51 .

faunas of northern, 73 .

Allorisma Winchelli, 88.

Alton, Pa.,exposures at, 102.

Ambocœlia umbonata Hall, 56, 59, 74, 75, 76, 78, 80 .

Ambocœlia umbonata Hall, var, 60.

Ambocœlia umbonata, var. recta, 56 .

Andrews, E. B., cited, 19.

Aneroid, use of, in determining elevations, 53.

Aptychus of Goniatites, $\mathbf{3}$ \%.

explanation of figures of, Pl. III, 112.

Aptychus of Goniatites ? of G. uniangularis, 35.

Aptychus ? or Spathiocaris? (Clark), 35 .

A renicolites, defined, 46.

Areuicolites duplex, n. sp., description of, $4 \mathbf{6}$. named, 47.

explanation of figures of, Pl. IV, 116.

Armstrong quarry, 63.

Ashburner, C. A., cited, 12, 19, 100.

Aspidichthys clavatus Newberry, 43.

Athyris Angelica, 58, 61, 64, 65, 66, 67, 68, 69, 73. 74,

Athyris Angelica fauna, 22.

$75,84,85,92,93,95,96$.

Athyris polita, 85 .

Attica, N. Y., exposures at, 31

Aulopora, sp., 77 .

A vicula, 34, 69.

A viculopecten, 78 .

Aviculopecten cancellatus, 67, 68 .

Aviculopecten, sp., 74 .

Aviculopecten, var., 64 .

B.

Barrois, eited, 13.

Beecher, C. E., cited, 18, note.

Belfast, faunas of concretionary nasses at, $\boldsymbol{\gamma} \mathbf{5}$.

Belfast quarry, section, exposure, and altitude at, 75.

Belgium, Devonian series of Northern France and, 13.

Bellerophon, near B. Euclid, 74.

Bellerophon, sp., 68,89 .

Bellerophon mœra, 59, 74.

Belmont, altitude and exposures at, 8.
Bennington section, $4 \%$.

Black Creek, altitude and exposures at, $7 \mathbf{1}$.

Black shales, Ohio, 24. relation of, to the upper faunas, 24 . relation of Verticalis sandstone to, $\mathbf{4 5}$

Bolivar, section, exposures, and altitude at, $\mathbf{8 9}$, Do.

Brachiopod fauna of Cuba sandstones, 64, 65, 66 .

Bradford, section and exposures at, 100. order of succession of faunas at, 101.

Bryozoan in Centronella Red Band, 56.

C.

Calceola, 35.

Caneadea, section, exposure, and altitude at, $7 \mathbf{5}$.

Caneadea Creek, dip along, 55 .

fauna of, 60.

section at, 60 .

lower part, section on, $\boldsymbol{7}$.

Carboniferous formation, variable nature of deposits preceding, 13.

Carboniferous series, Portage group the base-of the, 18 .

Cardiola, 35.

Cardiola fauna, 22, 34 .

Cardiola speciosa, $33,34,37,40,42,43,50,52,80$.

Cardium, 41.

Carll, John F., cited, 12, 19, 25.

Catskill and Chemung rocks, relations of, 27.

Catskill deposits in Western New York, 28.

Cayuga Lake section, 23.

Centronella Julia, 58, 59, 67.

Centronella Red Band fauna, 56.

Ceriopora, sp., 65, 66, 67, 78, 96, 100.

Chætetes, sp., 58, 68, 73, 74, 75, 76, 85

Champernowne, cited, 12.

Chance, H. M., cited, 12, 19.

Chantauqua Connty, sections examined in, 9.

Chemung, transition to red and green shales from, 85.

(See, also, Upper Chemung.)

Chemung fauna, 23, 24. strata following the, 25-2r. period of, 28.

lowest trace of, $\mathbf{4 9}$.

transition from the Portage to the, 80, 81 .

highest exposure of, 92.

Chemung flags of Erie and Crawford Counties, 19. 
Chemung group, included in Carboniferous by Newberry, 18.

in Pennsylvania and New York, 18, 19.

Portage sandstones and the faunas of the, 51-82.

Lingula shales in, $\boldsymbol{\gamma} \mathbf{1}$.

base of, 7 \%.

fauna of Upper, 100.

Chonetes, 34 .

Chonetes lepida, 34, 43, 64 .

Chonetes scitula, 58, 64, 65, 66, 67, 68, 74, 84, 96.

Cladochonus, 43,80 .

Clarksville, exposures at, 83 . altitude and exposures near, 86.

Cleveland shale at Bedford, 24, 25.

Coleolus acicula, $34,37,42,50,80$.

Coleolus (coleoprion) tenuicinctum, 80 .

Conglomerate, flat pebble, in New York, 21.

Conglomerates, sandstone, 20.

Conodont teeth, in Genesee shale, 32.

Cook quarry, south of Olean, section, exposures, and altitude at, $\mathbf{D r}$.

Crania, sp., 56, 67, 74.

Crenipecten, 78.

Crenipecten crenulatus, 74 .

Crenipecten (?) impolitus, 65

Crenipecten obsoletus, 74 .

Crinoid stems, $37,40,56,59,64,66,68,73,74,75,76$, $96,100$.

Cryptonella, sp., 77.

Crystal Brook, Warsaw, exposures at, $\mathbf{3 6}$.

Cuba, fauna of Red Bands south of, 22 .

Lingulas in the olive shales at, 32 .

section, exposures, and altitude at, $\mathbf{6 3}, \boldsymbol{\gamma} \mathbf{1}$.

Cuba sandistones, 63 .

Cyrtoceros (?) Hector, 86.

Cytherodon (Schizodtas) pauper (?), 56.

D.

Dames, eited, 38.

Daubree quarry, elevation of, 4 .

Dennis well, mentioned, 100.

Devonian, relations of, to Old Red Sandstone, 16. relation of eastern and western beds of,

Devonian age, diseussion of the problem of the, in Great Britain, 12.

difficulty of settling termination of, 13 . why chosen for investigation, 15.

Devonian series of Northern France and Belgium, 13.

(See, also, Upper Devonian.)

Dictyophyton, 77.

Dipterus Alleganensis, 63 .

Dipterus (?) lævis Newberry, 63. 89. explanation of figure of, Pl. III, 112.

Dipterus Nelsoni Newberry, 62. explanation of figure of, Pl. III, 112.

Discina, sp., 64.

$$
\text { E. }
$$

Earl station, altitude at, 47.

Eastern Hamilton fauna, 23.

Edmondia (?) Pbilipi, 64.

Entomis (?), 54.

Estheria, 54.

Etheridge, cited, 12, 16.

Euomphalus (?), 37 .

Euomphalus, sp., 6 .
F.

Faunas, fruitfulness of study of, 13. geographic and chronolugic relations of, 21. list of, 22.

relation of, to character of deposits, $\mathbf{2 3}$.

successive stages and changes, $\mathbf{2 8}$.

Ferruginous sandstone, fauna of, 22, 87. equivalent to sub-Olean conglomerate, 29-30.

Fish remains among Chemung fossils, description of, 62.

Fish scales, 77.

Flat pebble conglomerate, 22, 83, 91 .

Forbesiocrinus communis, 74 .

France, Northern, and Belgium, Devonian series of, 13.

Friendship, exposures at, 77.

Fucoid maŕkings, $\mathbf{2 9}, 59$.

Fucoides graphica, 47.

Fucoides verticalis, 40, 42.

G.

Genesee County, examination in, 9.

Genesee section, study of the, 9 .

Genesee shale and the Portage groups, faunas of, 31-50.

Glyptocardia, name proposed by Hall for Cardiola speciosa, 34 , note.

Glyptocardia speciosa Hall, 80.

Goniatites, 34, 41, 50.

Goniatites bicostatus, $40,42,80$.

Goniatites complanatus, 34, 40, 52.

Goniatites Patersoni, 42.

Goniatites uniangularis Conrad, 34, 37.

Goniophora Chemungensis, $67,78,86$.

Gosselet, cited, 13.

Grammysia communis, 64, 78, 88, 100.

Grammysia communis, var., 66.

Grammysia elliptica, 79.

Grammysia fauna of Cuba sandstones, 64.

Grammysia subarouata, 85, 88.

Great Britain, discussion of the Devonian problem in, 12.

Great Valley, N. Y., section, altitude, and exposures at, 91.

Guilford quarry, 63, 65.

H.

Hall, James, cited, 12. on Upper Devonian, 16, 17.

on relation of Chemung to Carboniferous, 17,18 . on relation of the Chemung to the Waverly,

18 , note.

proposes name Glyptocardia for Cardiola speciosa, 34 , note.

on Portage sandstones, 51.

Holoptychius, 27, 89, 94.

habitat of, 28.

scales, $26,101$.

Hyolithes, 34 .

Iowa Devonian fauna in New York deposits, 55.

Ithaca fauna, 23.

position of, 30 .

Ithaca group and its fauna, position of, 81 . 
J.

Java Center, altitude at, 49.

Java Village, exposure in ravine east of, 49.

Jukes, cited, 12.

K.

Kayser, Emanuel, cited. 13, 38.

Kinzua Creek sandstone, 99.

\section{L.}

Lamellibranch fauna, 22 .

Lamellibranchs, description of two new, $\mathbf{3 5}$.

Leda diversa, 42.

Leiorhynchus, 59,61 . fauna, 22,30 .

Leiorhynehus, sp., 75 .

Leiorhynchus (?) globuliformis, 100 .

Leiorhynchus mesocostalis, $56,60,61,77$.

Leiorhynchus multicosta, $60,61,77,80$.

Leiorhynchus sinuata, 60, 61 . sinuatus, 56.

Leperditia, 34, 54 .

Leperditia, sp., 35.

Leptodesma, 34, 67, 69, 84, 91, 100, 101.

Leptodesma, sp., 67, 84, 91.

Leptodesma lichas, 86, 91,

Leptodesma Mortoni, 68, 84, 85, 100, 101.

Leptodesma Mortoni, var., 83.

Leptodesma potens, $68,96$.

Leptodesma sociale, 66,67 .

Lesley, J. P., cited, 12, 18.

Lingula, 64, 70, 77.

modification of, 29.

Lingula fauna, 68.

of Chemung group, 22.

of Génesee shales, 22.

of Cuba sandstones, $\mathbf{6 4}$.

Lingula Melie, 29, 31, 64.

Lingula shales in the Chemung group, 1 .

Lingula spatulata, 29, 31, 33, 34, 35.

Lingula subspatulata, 31 .

Little Genesee, section, altitude, and exposures at, $\mathbf{8 7}$.

Loomis, J. V. D., aid of, 48.

Loxonema (?), 35.

Loxonema delphicola (?), 35.

Loxonema styliola, 74.

Lncina Varysburgia, n. sp., 40, 43, 44. explanation of figure of, Pl. III, 112.

Lucina Wyomingensís, n. sp., 40, 43, 44. explanation of figure of, Pl. III, 112.

Lunulicardium fragile, 34, 38, 42. explanation of figures of, Pl. III, 112.

Lunulicardium levis, n. sp., 34, 37, 39, 40. explanation of figures of, Pl. III, 112.

Lunulicardium Munster, 38.

Lyriopecten, sp. = ? L. orbiculatus, 67 .

Lyriopecten orbieulatus, 67 .

\section{M.}

Macoon quarry, 49.

Macrodon Chemungensis, 74, 78.

(?) Macrodon Chemungensis, 84.

Marshall group, A. Winchell on the, 17.
MeGee quarry, N. Y., section and altitude at, 49, $52,53$.

MeKean County, examination in, 9.

Meek, F. B., cited, 12.

Miller, P., aid of, 77 .

Modiola præcedens, 86, 89, 91.

Modiomorpha, 68.

Modiomorpha quadrula, 74 .

Modiomorpha subalata, 74.

Mount Raub, outcrops on, 100.

Mourlon, eited, 13.

Murchison and Sedgwick, cited, 12.

Mytilarca, sp., 78, 91.

Mytilarca Chemungensis, $58,67,68,74,84,85,89,96$.

\section{N.}

Naticopsis (?) sp., 53.

Newberry, J. S., cited, 12. on Ohio equivalent of the Chemung, 18.

New York, sections examined in, 9. flat pebble conglomerate in, 21 .

Western, shifting of faunas of, in Upper De. vonian time, 70.

New York series, relation of Waverly to, 17 .

Nucula, n. sp., 56.

Nucula, sp. (?), 74 .

Nucula corbuliformis, var., 43.

O.

Ohio, sections examined in, 9. order of deposits in, $\mathbf{2 0}$.

old Red Sandstone discussed in Great Britain, 12. relations between Devonian and, 16 .

Olean section, altitude and exposures at, $\mathbf{9 2}$.

Olean and Rock City, section, exposures, and altitude at, 95.

Olean conglomerate, 19, 83, 99, 101.

defined, 26, 99.

equivalent of, 103.

altitudes of, 103.

Olean-Garland-Ohio conglomerate, equivalency of, 19.

Olean section, yellow sandstones of, $\mathbf{9 5}$.

Orthis, sp., 62.

Orthis impressa, 29, 57, 59, 60, 72, 73, 74, 75, 76, 79.

Orthis Leonensis, 22, 67, 69, 74, 85 .

Orthis Michelini, 58, 59, 69.

Orthis Tioga, 30, 74, 76, 80 .

Orthis Tulliensis, 29.'

Orthoceras, $35,40,42,64,78,80,89$.

Orthoceras, sp., 91.

Orthoceras Demus, 59, 86.

Orthoceras pacator, 43,64 .

Orton, cited, 12.

\section{P.}

Palæanatina typa, 86, 89, 91, 101.

Palæoneilo, 41, 50, 61, 68, 70, 78.

Palæoneilo, sp., 64, 67.

Palæoneilo Bedfordensis, 68.

Palæoneilo brevis, var., 67,74 .

Palæoneilo plana, var., 52, 80.

Palæoneilo plana, var. Varysburgia, 41, 52, 80.

Palæoniscus, 33.

Palæoniscus seales, 32, 34, 35 . 
Pennsylvania geologists, views of, 18, 20.

Petroleum, occurrences of, 19, 20, 76.

Plant remains, 68, 96.

Platystoma, sp., 74 .

Pleurotomaria, 34.

Pleurotomaria, sp., 56, 65.

Pleurotomaria capillaria, 35, 40, 42.

Pleurotomaria filitexta, 67.

Portage, Cardiola fauna at, 30 .

Portage Falls, sandstones at, 24, 52.

Portage fauna, 24, 30, 37, 52. transition to Chemung from the, 80, 81 .

Portage green shales, 45.

Portage group, the base of the Carboniferous series, 18.

faunas of the Genesee shale and the, 31-50.

Portage sandstones, vertical fucoid markings in, how produced, 29.

relation of, to faunas of the Chemung group, 51-82.

Portageville, section at, 51 .

Portville, section, altitude, and exposures at, 90.

Portville conglomerate, fauna of, 91 .

Productella, 59, 65, 66, 69, 70, 74, 77 .

Productella, sp., 73.

Productella acutirostra, 73, 100.

Productella costatula, 58, 65, 66, 67.

Productella costatula, var., 78,84 .

Productella hirsuta, 56, 58, 66, 74, 75, 76, 77, 79, 84.

Productella hystricula, 95, 96 .

Productella lachrymosa, 57, 59.

Productella lachrymosa, var., 76.

Productella lachrymosa, var. lima, 100.

Productella lachrymosa, var. stigmata, 61, 74.

Productella onusta, 58, 65, 75.

Productella rarispina, 74 .

Productella Shumardiana, var., 56.

Productella speciosa, 56, 80 .

Prospiraxis (=Spiraxis Randalli, var. Newberry), name proposed, 86 , note.

Pterinea Goldfuss, classification of, 36 .

Pterinopecten, sp., 84.

Pterinopecten Atticus, n. s., 33, 35, 37, 112. explanation of figures of, Pl. III, 112.

Pterinopecten suborbicularis, 64, 74.

Ptilophyton, 97.

Ptychopteria, near P. Eugenia (= P. Salamanca Hali), 74.

Ptychopteria (?) mesocostalis, n. sp., 35, 37. explanation of figure of, Pl. III, 112.

Ptychopteria Salamanca Hall, 74.

\section{R.}

Randall, F. A., cited, 18, note.

Raub, Mount, outcrops on, 100.

Reed, W. T., aid of, 90.

Rhenish Devonian, Emanuel Kayser cited on, 13:

Rhodea, 97.

Rhynchonella, 61, 87, 101.

Rhynchonella, sp., $68,76,84$.

Rhynchonella Allegania, n. sp., 93. description of, $\mathbf{8 7}, \mathbf{8 8}$.

explanation of figures of, PI. IV, 116.

Rhynchonella (?) camerifera, 56.
Rhynchonella contracta, 58, 59, 61, 64, 65, 66, 67, 73, $74,75,78,79,80,83,84,85,88,89,90,91,93,95$, $96,100$.

Rhynchonella contracta, var., 56, 58.

Rhynchonella contracta, var. saxatilis Hall, 58, 96.

Rhynchonella duplicata, 65 .

Rhynchonelia eximia Hall, 56 .

Rhynchonella (?) Sappho, var., 62, 74, 77.

Rhynchonella Stephani, var., 61, 80 .

Richburg sands, 90.

Rock City, defined, $\mathbf{8}$.

section and exposures between Olean and, $9 \boldsymbol{\gamma}$.

Rock City conglomerate, upper, 99.

Rockville, section, altitude, and exposures at, $\boldsymbol{\gamma} 3$.

Rominger, Carl, eited, 12.

Rushford, section and altitude at, 55 .

Rushford sandstone fauna, 56-60.

\section{S.}

Salter, cited, 12.

Sandstone, Old Red, relations between Devonian and, 16.

micaceous, 26.

Cuba, 63.

Sandstone (brownish red) fauna, 22.

Sanguinolites, 64, 69.

Sanguinolites clavulus, $68,85,96$.

Sanguinolites rigidus, $64,65,68,74,84,96$.

Sauropterus Taylori, 101.

Schizodus oblatus, 101.

Schizodus rhombeus, 96.

Schizodus rhombeus, var., 64.

Sections, system used in marking, 10.

Section 487 B, 95.

Sedgwick, cited, 12.

Shean excaration above Caneadea, re.

Sierk's station, section and altitude at, 48 .

Smith's quarry, 63. section at, $\mathbf{6 5}$.

Spathella typica Hall, 84.

Spathiocaris (?), 35 .

Specimens, system used in marking, 10.

Sphenotus clavulus Hall, 85, 88, 90, 96.

Sphenotus contractus Hall, 64, 65, 68, 74, 84 .

Spiraxis, 89.

Spiraxis (?) major Newberry, 86.

Spiraxis (?) Randalli, var. Newberry, 86.

Spirifera, 28, 54, 101.

Spirifera, sp., 84 .

Spirifera disjuncta, 24, 56, 57, 58, 59, 64, 65, 66, 67, 68, $69,72,73,74,77,78,84,87,88,89,90,93,94,95,96$, $100,101$.

fauna, 22 .

Spirifera disjuncta, var. like S. Whitneyi, 58.

Spirifera mesocostalis, $56,57,58,59,60,61,62,72,73$, $74,75,76,79,80,81$.

fauna, 22 .

modification of, 28 .

location of, $\mathbf{3 0}$.

Spirifera Verneuili, occurrence of, below the Cleveland shale, 17.

Spirifera (?) Whitneyi, 58.

Spiriferina, 28.

varietal modification of, 29 .

S rirophyton, $47,48$. 
Spirophyton cauda-galli, 45.

Spirophyton velum, 46.

Sporangites, 23, 32, 33, 34, 35, 37, 39, 41, 47, 48 .

Stony Brook, exposures and fauna at, 41.

Streptorhynchus, 57, 65 .

$$
\text { fauna of, } 22 .
$$

Streptorhynchus Chemungensis, 58,59, 62, 64, 65, 66

Styliola, 34, 35 . $67,68,69,70,74,75,76,79$.

Styliola fissurella, 34, 37.

Sub.Olean conglomerate, 19.

equivalent to ferruginons sandstone, 29, 30.

\section{T.}

Tonawanda Creek, exposinres on, 31 .

Tonawanda Valley and Cuba Railroad quarry, 40

\section{ए.}

Ungulina suborbicularis, 44 .

Upper Chemung, order of deposits of, 69. sands and conglomerates of the, 83-104. characters marking the close of the, 95 . fauna, $95,100$.

Upper Devonian, comparison of faunas of, 11. opinions on the classification of rocks and faunas of the, 15-20.

variqus opinions regarding classification of, 16-19.

confusion in regard to fossils of, 18. arrangement of deposits of, 19.

shifting of faunas with passage of, ro.

Upper Portage group included in Carboniferous by Newberry, 18.
V.

Varysburg, sections at, 39, 40. exposures and fauna at, 41.

Venango group in Chemung flags, 19.

Venango oil group, place of, $\mathbf{2 5}$.

Venango oil sands, 19.

Verticalis borings, $42,45,46,63$.

Verticalis sandstone, $\mathbf{4 5}, 47$. name proposed, $\mathbf{2 9}$. named, 42.

in Upper Portage, 43.

relation to black shales, 45 .

relations of, 48.

W.

Warsaw, altitudes at, $\mathbf{3 6}$.

Waverly group, relation of, to New York series, 17.

Winchell on position of, 17 .

Waverly sandstone in Pennsylvania and New York, 18 .

Wellsville, exposures and altitude at, $\boldsymbol{\gamma} \boldsymbol{\gamma}$.

White, C. A., cited, 12.

White, I. C., cited, 12, 19, 25, 27, 103.

Winchell, A., cited, 12.

on the Marshall and Waverly groups, 1 r.

Wolf Creek, section and altitude at, 86.

Wolf Creek conglomerate, 86.

Woodward, H., cited, 38.

Worm tracks, description of, 46.

Worthen, A. H., cited, 12.

Wyoming County, Portage sandstones in, 51. 
